\title{
Kernos
}

Revue internationale et pluridisciplinaire de religion grecque antique

7| 1994

Varia

\section{Epigraphic Bulletin for Greek Religion 1990}

\section{Angelos Chaniotis and Eftychia Stavrianopoulou}

\section{OpenEdition \\ Journals}

\section{Electronic version}

URL: http://journals.openedition.org/kernos/1113

DOI: $10.4000 /$ kernos. 1113

ISSN: 2034-7871

\section{Publisher}

Centre international d'étude de la religion grecque antique

\section{Printed version}

Date of publication: 1 January 1994

ISSN: 0776-3824

\section{Electronic reference}

Angelos Chaniotis and Eftychia Stavrianopoulou, « Epigraphic Bulletin for Greek Religion 1990 », Kernos [Online], 7| 1994, Online since 20 April 2011, connection on 16 September 2020. URL : http:// journals.openedition.org/kernos/1113 
Kernos, 7 (1994), p. 287-354.

\section{EPIGRAPHIC BULLETIN FOR GREEK RELIGION 1990 (EBGR)}

This fourth issue of $E B G R$ presents the publications of 1990 , numerous publications of 1989 omitted in the previous issue and several addenda to EBGR 1987 and 1988. The principles explained in Kernos, 4 (1991), p. 287-288 apply also to this issue.

We would like to express our gratitude to various scholars for encouragement and helpful criticism. Unfortunately, we cannot replace the alphabetical arrangement of the works presented here with a thematic or geographical one (as suggested by P. GAUTHIER, in $B E 1992,1$ ) for reasons explained in the first issue; but we hope that the detailed survey of selected topics facilitates work with the bulletin.

This bulletin is addressed primarily to scholars interested in Greek religion, and not to epigraphists; accordingly, the original intention was to discuss epigraphic publications which could escape the notice of historians of Greek religion. Our bulletin is not a general bibliography on Greek religion; the limited space available forces us to exclude from our presentation books and articles, whose titles indicate clearly their religious scope. However, in order to present in an adequate manner the contribution of inscriptions to the study of Greek religion (and partly contrary to the original intention), we include a very brief presentation of selected works, which are devoted exclusively to religious matters and make extensive use of inscriptions (e.g. some volumes of the Études préliminaires aux religions orientales dans l'Empire romain). These works are marked with an asterisk.

The abbreviations used are those of L'Année Philologique and the Supplementum Epigraphicum Graecum. We are aware of the fact that many publications escape our notice. The sending of offprints, especially of less accessible publications, would certainly help our work.

We are very much obliged to Dr. Angela Schneider for improving the English text.

\section{Additional abbreviations}

Anathema :

G. Bartoloni - G. Colonna - C. Grotanelli (edd.), Atti del convegno internazionale "Anathema. Regime delle offerte e vita dei 
Arabie préislamique:

Archeologia Cirenaica:

AST:

Entre hommes et dieux:

Greek Renaissance:

santuari nel mediterraneo antico, Roma 15-18 Giugno 1989, in Scienze dell'antichità, 3-4 (19891990) [1991].

T. FAHD (ed.), L'Arabie préislamique et son environnement historique et culturel. Actes du Colloque du Strasbourg, 10, Strasbourg, 1989.

Giornata Lincea sulla archeologia cirenaica (Atti dei Convegni Lincei, 87), Roma, 1990.

Arastirma Sonuclari Toplantisi.

A.-F. LAURENS (ed.), Entre hommes et dieux. Le convive, le héros, le prophète , Paris, 1989.

S. Walker - A. Cameron (edd.), The Greek Renaissance in the Roman Empire (BICS, Suppl. 55), London, 1989.

Festschrift Himmelmann: H.-U. Cain - H. Gabelmann - D. Salzmann (edd.), Festschrift für Nikolaus Himmelmann, Mainz, 1989.

Festschrift Inan:

N. BASGELEN - M. LUGAL (edd.), Festschrift für Jale Inan, Istanbul, 1989.

Hommage à G. Roux:

R. ÉTIENNE - M.-T. LE DINAHET - M. Yon (edd.), Architecture et poésie dans le monde grec. Hommage à George Roux, Lyon-Paris, 1989.

KST:

Mneme Lazaridi:

Kazi Sonuçlari Toplantisi.

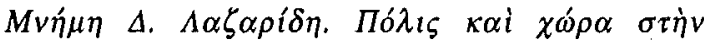

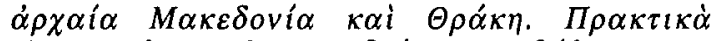

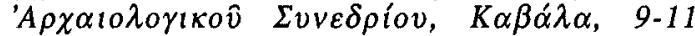
Maiov 1986, Thessalonike, 1990.

Mysische Studien:

E. Schwertheim (ed.), Mysische Studien (Asia Minor Studien, 1), Bonn, 1990.

Peloponn. Spoudes:

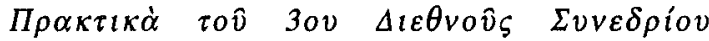
$\Pi \varepsilon \lambda o \pi \circ v v \eta \sigma t \alpha \kappa \hat{\omega} v \quad \Sigma \pi o v \delta \hat{\omega} v, K \alpha \lambda \alpha \mu \alpha \dot{\tau} \alpha, \quad 8-15$ $\Sigma \varepsilon \pi \tau$. 1985, Athens, 1987-1988.

Poikila:

RESEARCH CENTER FOR G REEK A ND ROMAN ANTIQUITY, Пlotki $\lambda \alpha$ (Meletemata, 10), Athens, 1990.

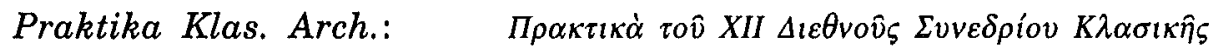

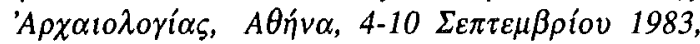
vol. 2-4, Athens, 1988.

Syrie:

J.-M. Dentzer - W. ORThmann (edd.), Archéologie et histoire de la Syrie. II. La Syrie de l'époque achéménide à l'avènement de l'Islam, Saarbrücken, 1989. 


\section{Selected topics}

Geographical areas (in the sequence adopted by the $S E G$ )

Attica: 8. 30. 33, 45. 50.52. 57.63, 64. 65. 66, 86. 90. 93. 108, 121.129. 132. 134. 135. 143. 144. 148. 150. 151. 155. 159. 172. 188. 208. 209. 213. 227. 228. 234. 241. 245. 246. 277. 296. 306. 313. 321. Peloponnesos: 21. 40. 51. 55. 57. 85. 122. 123. 169. 171. 178. 196. 198. 231. 236. 237. 242. 245. 285. 292. 298. 299. 319. Boiotia: 128. 261. 262. Delphi: 73. 82. 124. 221. 266. 267. Aitolia: 10. Ionian islands: 291. Thessaly: 56. 65. 91. 107. 113. 139. 149. 216. 276. 307. Epeiros: 9. Illyria: 207. Macedonia: 4. 59. 60. 75. 126. 153. 156. 170. 183. 184. 194. 235. 237. 245. 294. 300. 302. 303. 305. 316. 317. 318. Thrace: 26. 78. 109. 162. 174. 176. 199. 212. 224. 240. 315. North Shore of the Black Sea: 25. 46. 80. 98. 111. 179. 206. 272. 279. 301. 314. 327. Delos: 20. 44. 270. Dodecannes: 117. 131. 154. 205. 233. 326. Cyclades: 84. 177. 210. 211. 322. Samos: 54. 116. Lemnos: 12. Thasos: 49. 263. Samothrake: 95. Euboia: 142. 161. 193. 254. Crete: 11. 27. 38. 54. 120. 145. 152. 175. 189. 256. 297. Sicily: 37. 99. 100. 203. 204. Italy: 3. 16. 17. 18. 34. 62. 70. 99. 185. 214. 215. 218. 232. 243. 289. 293. 304. Danubian Provinces: 78. 102. 167. 168. 273. 315. Gallia: 19. 250. Britannia: 97. Asia Minor: 119. 160; Karia 32. 225. 226. 248. 251. 258. 265. 268. 271. 323; Ionia 14. 71. 80. 82. 83. 104. 105. 274. 320; Lydia 53. 125. 165. 182. 201. 247. 309; Aiolis 130. 136. 253; Troas 243; Mysia 53. 119. 158. 187. 252. 275; Bithynia 67; Pontos 96. 230; Phrygia 41. 133. 160. 163. 197. 260; Pisidia 157; Pamphylia 53. 88. 138. 264; Lykia 94. 166. 190. 191. 278; Lykaonia 81; Kilikia 79. 281. Cyprus: 48. 65. 222. 223. Mesopotamia: 24. 39. 140. Baktria: 324. Syria: 35.72. 164. 181. 219. 269. 295. 311. Palaestina: 110. 141. 200. Arabia: 47. 244. 249. Egypt: 1. 2. 22. 23. 28. 29. 31. 36. 48. 68. 87. 127. 255. 280. 282. 283. 284. 325. North Africa: 103. 147. 192. 238. 241. 257

acclamations: 264

amulets: 97.220

animals in cult: bull (and Dionysos) 113; cows (and Athena) 49; dogs (sacrifice of) 10; dolphins (and Poseidon) 307; goat 113; lion (and Magna Mater) 70; ram (and Dionysos) 113; snake (heroic cult) 170.246

anthropomorphic figurines: 5

apotropaic inscriptions / symbols: 92. 203. 218

aretalogies: 217.325

arkteia: 241

associations: 6. 127. 159. 229. 252. 261. 295. 302. 304.322

asylia: 15. 47. 57. 82. 264. 295. 298. addenda

banquet: 3. 25. 72. 79. 85. 134. 218. 258. 319

benedictions: 2.68

birthdays: 29.31 
Buddism: 324

calendar: 55. 111. 162. 199. 242. 316

carrying of objects (in processions): 14. 22. 212. 229. 295

Christianity: 94.137

chthonic cults: 25. 232. 279. 293. 307. 321

'confession inscriptions': 53. 125. 137. 182. addenda

contests: see festivals

crowns: 193 (ivy-crowns). 253 (of priests), 275 (funerary)

cult images: 5. 22. 74. 131. 229

cult objects/paraphernalia: 3. 35 (thymiaterion). 134 (rhyton). 136 (spondeion). 184 (perirrhanterion)

cults of cities/areas (a selection): Kynouria 85; Tanagra 261. 262; Aitolia 10; Pherai 216; Beroia 294; Thessalonike 302; Thrace of the Propontis 199; Chersonesos (Pontos) 272; Ialysos 233; Neapolis 215; Stratonikeia 268; Hierapolis (Phrygia) 260

curses: 37. 48. 86. 99. 100. 102. 147. 148. 192. 206. 321; see also funerary imprecations

death: 99. 118. 149. 218. 276. 311

dedications: 4. 5. 7. 44. 72. 145. 146. 186. 195. 221. 285; 'anatomical votivs' 92. 93; anthropomorphic figurines 5; clothes 261; footprints / soles 77; mirrors 19. 151; spoils 21. 122; 'steps' 96; torches 245; after a victory 21. 24. 122. 123. 124; replacement of $d .146$; melting down of $d$. 195; dedicatory formulas 157. 186. 189. 205; d. made by members of the same family: 151. 169

defixiones: see curses

deification: 29. 31. 64 (Antinoos). 317 (Hephaistion)

deities (a selection; new and rare deities, deities attested for the first time in a place, deities discussed thoroughly): Agathos Daimon (Palaestina) 110; Aphrodite (Pella) 194; Aphrodite Basilis (Taras, Sparta) 232; Apollon Alsios 288; Apollon Apotropaios (Massalia) 250; Apollon Aularkenos (Thrace) 176; Apollon Christerios (Myrina) 253; Apollon Delphinios (Olbia) 46; Apollon Didymaios (Milet, Olbia) 46; Apollon Gryneios (Myrina) 253; Apollon Hekatombios (Macedonia) 156; Apollon Iatros 46. 80; Apollon Komaios (Seleukeia on the Tigris) 24. 140; Apollon Kendrisos (Philippoupolis) 26; Apollon Maleatas (Epidauros) 178; Apollon Oulios (Elea) 304; Apollon Pythaieus 85 (Kynouria). 154 (Halasarna, Kos); Apollon Tyritas (Kynouria) 85; Artemis Agrotera (Eleutherna) 152; Artemis Kolenis (Eretria, Attica) 161; Artemis Katagogis (Kyrene) 241; Artemis Laphria (Aitolia) 10; Artemis Leukophryene (Kilikia) 281; Artemis Perasia (Kilikia) 281; Artemis Pergaia (Limyra) 278; Artemis Proskopa (Apollonia) 207; Asklepios/Asklepieia: 4. 20. 50. 80. 83. 85. 90. 
126. 168. 196. 229. 238; Athena Krisoa Oreia (Kilikia) 79; Athena Latmia (Herakleia at Latmos) 323; Athena Mykesie (Thasos) 49; Bona Dea 42; Boule (Hierapolis, Phrygia) 260; Demeter (Poseidonia) 62; Dea Roma 83; Demeter Thesmophoros 194 (Pella). 263 (Thasos); Demos 79. 116. 166. 258. 260; Despoina (Lykosoura) 198; Diktynna (Massalia) 250; Dionysos 50. 75. 113. 129. 133. 134. 139 (Pherai). 142. 158. 187. 193. 211. 261. 276; Dionysos Eleuthereus (Athens) 66; Dionysos Kathegemon 252 (Pergamon). 260 (Hierapolis, Phrygia); Eileithyia (Eretria) 161; Eleuthera (Lykia) 166; Epops (Attica) 135; Hebon (Neapolis) 215; Hekate Stratia (Halasarna, Kos) 154; Helios (Macedonia) 305; Hera (Naxos, Sicily) 204; Hera Eleutheria (Kroton) 289; Hera Lakinia (Kroton) 289; Herakles 140 (Seleukeia on the Tigris). 208 (Attica). 272 (Chersonesos). 310; Hermes (Halasarna, Kos) 154; Hermes Eriounios (Athens) 321; Hermes Prytaneios (Kea) 210; Hestia Boulaia (Paphos) 223; Kybele (Pella) 194; Maleatas (Kynouria) 85; Men Askainos (Pisidia) 157; Nemesis (Karallia) 53; Panakeia (Kyrene) 238; Pantes Theoi (Kydonia) 38; Parparos (Kynouria) 85; Periesto (Stryme) 174; Polemokrates (Kynouria) 85; Populus Romanus 116; Poseidon Aisios (Delos) 270; Poseidon Patragenes (Thessaly) 307; Theos Epekoos (Aphrodisias) 265; Theos Hyetios (Crete) 297; Theos Hypsistos 175 (Crete). addenda (Cyprus); Theos Kisinos (Rome) 218; Zenoposeidon (Mylasa) 271; Zeus Aglaios (Herakleia) 34; Zeus Ampelites (Phrygia) 163; Zeus Atabyrios (Ialysos) 233; Zeus Beudenos (Lydia) 201; Zeus Bozios (Hierapolis, Phrygia) 260; Zeus Eleutherios (Olbia) 314; Zeus Homoloios (Thessaly) 56; Zeus Hypsistos 59. 60. 75. 93. 224. 302. 315; Zeus Idaios (Crete) 54; Zeus Kassios 273; Zeus Kataibates (Halasarna, Kos) 154; Zeus Keraunios 37. 58; Zeus Machaneus (Eleutherna) 152; Zeus Messapios (Lakonia) 51; Zeus Osogollis (Mylasa) 32. 271; Zeus Thallos (Phygia) 163; Egyptian d.: 1. 22. 23. 31. 61. 77. 87. 127. 136. 168. 215. 217. 218. 255. 256. 261. 273. 282. 283. 284. 295. 302. 315. 325; female d.: 10. 194. 294; Oriental d.: 6. 20. 33. 70. 96. 97. 168. 180. 181. 194. 218. 219. 244. 272. 294. 295. 296. 302. 312.315

deities, protectors of agriculture: 272 ; of cities: 72.159 ; of fertility: 10 ; of monarchs: 39. 106. 252. 273; of navigation: 61. 159. 259. 270

divination: 46. 65. 305. 309; see also oracles

Eleusis: 63. 64. 121. 209. 234. 295

emperor cult: 9. 89. 106. 119. 133. 138. 160. 171. 177. 213. 218. 229. 236. 245.

247. 252. 257. 258. 259. 260. 264. 265. 274. 302. 320

ephebes: 119. 142. 228. 277

epiphany: 77 
festivals: 14. 27. 30. 41, 43. 45. 47. 50. 55. 66. 67. 82. 83. 84. 85. 104.106. 129. 142. 154. 185. 208. 226. 227. 229. 237. 242. 245. 246. 248. 250. 251. 264. 275. 277. 290. 296. 314. 319.326

fire: 281

footprints (in sanctuaries): 77

foundations: 215. 247. 322

funerary cult: 101 . 134. 276; altars 81.166 .305 ; banquets 85 ; dedications 197 (to Hekate); honours 214. 275; imprecations 41. 79. 164. 167. 309 ; invocations 293; legislation 101; see also graves

Gnostism: 40. 239

graves, bouandary stones of: 172 ; violation of g.: 229

groves: 253

hands: 203

healing deities: 159. 174; see also deities, Asklepios/Asklepieia

heroes, heroic cult: 134. 135 (Epops). 143 (Erechtheus). 144 (Erechtheus). 159 (Erechtheus). 170. 237 (Aulonites). 188 (Keramos). 215 (Eumelos). 227 (Aglauros). 228 (Makaria). 246 (Amphiaraos). 261 (in Tanagra). 279 (Achilleus). 308. 317 (Hephaistion). 317. 322; see also deities, Herakles

hymns: 279.325

incense: 35

initiation: 241. 276

inventories: see sanctuaries

invocations: 92. 111. 120. 218. 220. 247. 264. 273. 293

ivy: 193. 276 (in Dionysos' cult)

Judaism: 137. 147. 173. 265

ktistes: 141

leges sacrae: 43. 57. 73. 84. 101. 104. 121. 130. 135. 142. 152. 159. 193. 241. 243. 261. 266. 310. 323. addenda

libation: 104,136

magic: 36. 37. 40. 48. 53. 69, 86. 99. 100. 102. 114. 147. 148. 220. 239. 286. 301. 304. 321

manumission: 10. 289. 294

milk: 276

miracles: 142.273 .297

months: see calendar

moon: 40.181. 220

mysteries: 54.64

mythology: 135. 218. 227. 262. 301

names, theophoric: 1. 11. 33. 80. 111. 223. 230. 262. 294; mythological: 262; names of deities given to phylai: 165; to phratries: 215; to gates: 314 
numbers: 46

nympholepsy: 65

Nymphs: 65.109

oath: 192

oracles: 46.193 .200 .253 .261 .267 .292 .314 .323

Oriental influence: 46

Orphism: 34. 50.54. 91. 99. 107. 113. 149. 276

paganism, late: 50. 54. 94

philosophy and religion: 50 (Neoplatonism). 107 (Herakleitos); 304 (Parmenides). 324

Phoenicians: 6. 20. 33

phylacteries: see amulets

pilgrimage: 23. 27. 73. 280. 313

politics and religion: 106. 142. 143. 232. 295. 326

possession: 65

prayer: 104.313

priests: 117 ; children as p.: 42. 309; election of: 323; eponymous: 79. 103. 126. 316; families of p.: 84. 160. 319. 323; iteration of office: 323 ; for lifetime: 119. 215. 323; royal administration and p.: 27. Other cult officials: archiboukolos 252; archiereus Asias 160; asiarches 160; chrysophoros 320; hiereus epi Skiados 155; hieromnemon 103; hieropoios 84. 154; hymnodos 229. 274; hymnodos Asias 119; kosmophoros 14; laukelarchesas 215; neokoros 260. 271; neopoiai 251; prostates Isidos 87; theagos 22; theokolos 10

processions: 142 . 193. 212. 229. 295; see also carrying of objects in p.

proskynema: see pilgrimage

purification: 10.80

rituals: 43 (theoxenia)

royal cult (Hellenistic): 126. 131. 158. 187. 240. 252. 254. 270. 295

sacrifice: 8. 10. 112. 135. 152. 279; sacrificial calendars: 129. 159. 209

sanctuaries: 32 ; accomodation of pilgrims 73 ; administration of 271 ;

boundary stones 235; finances 4. 7. 72. 79. 103. 108. 150;

inventories of 3. 44. 108. 195. 243; jurisdiction in 57. 292. 298. 299;

land of 7. 32.72. 150. 248. 295; privileges of 229. 248. 295; reloca-

tion of 47.249 .261 ; treasures 4.7 .150

slaves, refuge in sanctuaries: 57

soul: 113

stars: 40.220 .239

statues, abduction of: 24.39

sun: 181. 220. 230.244. 305

supplication: 178. 295. 298

symbols / symbolism: 40. 46. 92. 220. 239. 295 
syncretism: 20. 24. 26. 33. 35. 72. 79. 200. 244. 279. 295. 324

theoria, theoros: 33. 73. 117; theorodokos: 55.73

Thracian rider god: 109

torch-races: 245. 277. 296

'visiting gods': 5

wine: 113. 275. 276

women: 217. 241. 261. 319

\section{Greek words}

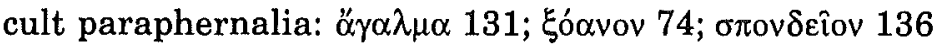

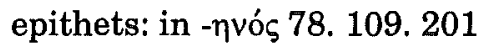

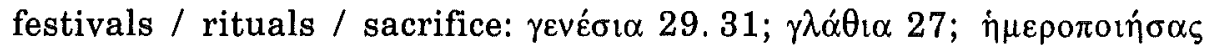

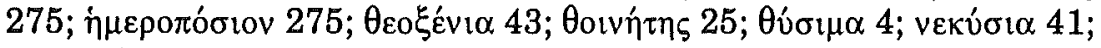
$\pi \alpha v v v \chi i \varsigma s 27$

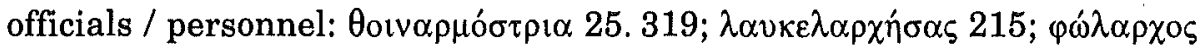
304

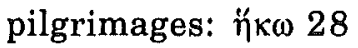

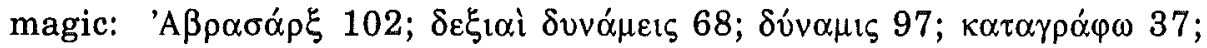

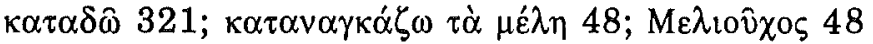

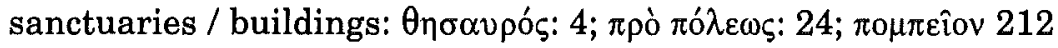

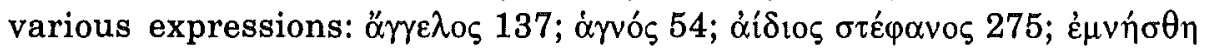

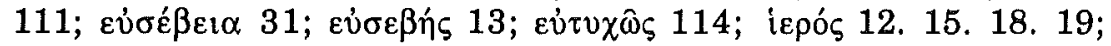

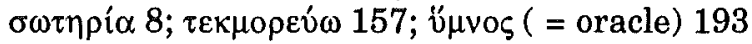

1) M. Abd El-Maksoud - J.Y. CARREz-Maratray, Une inscription grecque de la forteresse de Péluse, in CRIPEL, 10 (1988), p. 97-103 [SEG 38, 1840]: Honorary inscription from Pelusion (Egypt, 3rd c. AD) with the theophoric names Isidorion (father) and Kasios (son); both names are related to the principle deities worshipped in Pelusion (Isis, Zeus Kasios). [AC]

2) M. Abd El-Maksoud - G. WAGNer, L'inscription grecque du grand bain romain de Péluse, in CRIPEL, 11 (1989), p. 135-138: Mosaic inscription

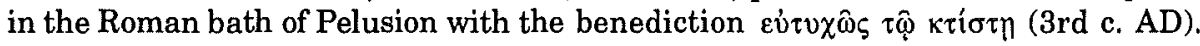
[Cf. infra $\mathrm{n}^{\circ}$ 68]. [AC]

3) A. Alesio - P.G. Guzzo, Santuari e fattorie ad est di Taranto. Elementi archeologici per un modello di interpretazione, in Anathema, p. 363396: Presentation of a field survey in the area of Taras. A.-G. discuss a list of agricultural implements and cult objects belonging to a sanctuary of Artemis ( $E B G R$ 1987, 65); they interpret it as an inventory of cult implements used in a ritual, on which animals were sacrificed and partly burned, partly consumed at a banquet. [According to $\mathrm{L}$. DuBoIS it is an inventory of cult objects delivered by potters and smiths: see $E B G R$ 1989, 30; cf. infra $\mathrm{n}^{\circ} 243$ ]. They also discuss some terms ( 


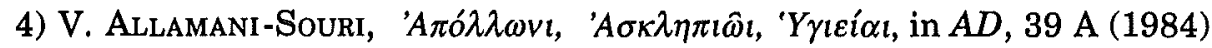
[1990], p. 205-231 [BE 1991, 389]: Ed. pr. of a list of dedications made every year by the priest of Asklepios after his term of office at the Asklepieion of Beroia (ca. 240-225). Each registration includes a dedicatory formula naming Apollon, Asklepios and Hygieia, the name of the priest, the sources of the revenues ( $\dot{\alpha} \pi \dot{\alpha} \tau \hat{\omega} \mathrm{v}$

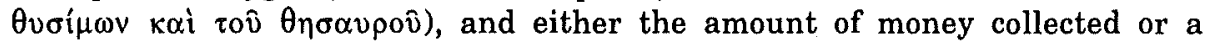
description of the objects dedicated to these gods. The word $\theta v \sigma u \alpha$ designates the sacrificial animals offered by the visitors of the sanctuary and the revenues deriving from the sale of their meat, wool, and skin. The treasure of the sanctuary

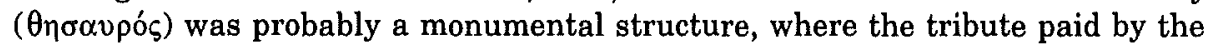
visitors of the Asklepieion was collected. [On the treasures of sanctuaries see now G. KaminsKI, Thesauros. Untersuchungen zum antiken Opferstock, in JdI, 106 (1991), p. 63-181 and infra $\left.\mathrm{n}^{\circ} 7\right]$. The money deriving from these two sources was used for the dedication of (silver?) vases of various types ( $\dot{\alpha} \rho \gamma_{0} \lambda_{1}$ kóv, $\dot{v} \pi \circ \varphi_{1} \alpha^{\prime} \lambda_{10}$,

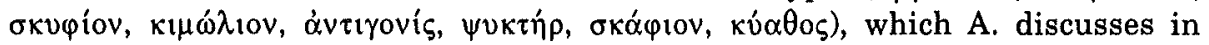
detail. In two cases the dedicants were not the priests themselves, but relatives (sons or grand sons) acting on behalf of them (ivép), probably after the death of the priests. A. suggests that the Asklepieion of Beroia was associated with those of Trikka and Epidauros and was organized on the same basis as the other Greek Asklepieia. A. offers a detailed commentary on the cult of Asklepios in Macedonia; she refers to the recent suggestion of M.B. HATZOPOULOS [BE 1988, 847] that the priests of Asklepios were the eponymous priests of the Macedonian cities; cf. M.B. HATZOPOULOS, in BE 1991, 389; on the cult of Asklepios in Macedonia cf. $E B G R$ 1989, 46]. [AC]

5*) B. Alroth, Greek Gods and Figurines: Aspects of the Anthropomorphic Dedications, Uppsala, 1989 [SEG 39, 1849]: A. studies two problems concerning the dedication of anthropomorphic figurines in Greek sanctuaries of the archaic and classical times: a) their relation to the cult image of the sanctuary; b) the dedication to a god of figurines representing another deity ('visiting gods'). A. makes ample use of inscriptions in her study of the phenomenon of 'visiting gods'; this practice is traced back to the archaic period. The material found in 20 sanctuaries shows that there were no standard combinations between the visiting gods and the deity, whom their figurines were dedicated to; these dedications can be explained by a variety of reasons. [AC]

6) W. Ameling, Koıvòv $\tau \hat{\omega} v \Sigma_{\imath} \delta \omega v i \omega v$, in $Z P E, 81$ (1990), p. 189-199: A. argues (against the view of J. TEIXIDOR) that the korvòv $\tau \hat{\omega} v \Sigma_{1} \delta \omega v i \omega v$ in $I G \mathrm{II}^{2}$ 2946 was a cult association of the Sidonians living in Piraeus; he collects the testimonies for this meaning of the word korvóv and the attestations of other similar Phoenician associations. [AC]

7) C. Ampolo, Fra economia, religione e politica: Tesori e offerte nei santuari greci, in Anathema, p. 271-279: Reflections on the economic and political rôle of the treasuries of Greek sanctuaries. A. discusses the use of the temple treasuries by Greek cities in times of need [cf. $E B G R$ 1988, 118], the origin and non-monetary character of the treasuries (mainly dedications), and the economic rôle of sanctuaries as reflected in their accounts. Discussion of the accounts of the Eleusinian sanctuary ( $\left.I G \mathrm{II}^{2} 1672.2630\right)$ and of an enigmatic 
inscription from Sicily [now L. DuBOIs, $E B G R$ 1989, $30 \mathrm{n}^{\circ} 177$ ]; the latter concerns according to $\mathrm{A}$. a leaseholder of sacred land. $[\mathrm{AC}]$

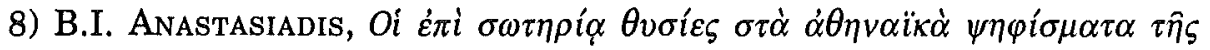
$\dot{\varepsilon} \lambda \lambda \eta \nu \iota \sigma \tau \iota \kappa \hat{\varsigma} \varsigma \dot{\varepsilon} \pi \circ \chi \bar{\eta} \varsigma$, in Hellenika, 41 (1990), p. 225-233: After an analysis of the notion of $\sigma \omega r \eta p^{i} \alpha$ in the written sources in connection with critical situations, $A$. studies the offering of sacrifices for the salvation of the boule and the people in Athens (earliest attestation in $343 / 2 \mathrm{BC}$ ). In some cases the typical fomula referred not only to the council and the people, but also to the allies, friends and benefactors of the city, thus associating Athen's salvation with the well-being of her friends. The addition of the "children and women" in this formula since the early 3rd c. can be interpreted as a dramatic emphasis in periods of severe dangers; similar formulas were used outside of Athens in Hellenistic times, usually in critical situations. [AC]

9) I. ANDREou, in $A D, 39$ B (1984) [1989], p. 191 [SEG 39, 528; $B E$ 1992, 286]: Mention of an altar dedicated to Hadrian, Zeus Olympios, and Zeus Dodonaios (Nikopolis). [P. CABANES, in $B E 1992,286$ rightly points out that Hadrian is identified with Zeus Olympios and Dodonaios; cf. $E B G R$ 1987, 11]. [AC]

10*) C. Antonetti, Les Étoliens. Image et religion, Paris, 1990 [BE 1991, 358]: In the second part of her book (p. 151-351) A. offers an excellent study of the cults and sanctuaries of Aitolia from the Mycenaean to the late Hellenistic times in the light of the literary, archaeological and epigraphic sources: Presentation of the sanctuaries of Apollon at Thermos (p. 151-209) and of Aphrodite Syria in Phistyon (p. 230-235, where many records of sacred manumis sions were found); discussion of the cult of Artemis Laphria in Kalydon (p. 244-262). A.'s study shows the predominance of female deities (especially Artemis Laphria), often worshipped as protectors of fertility (Demeter and Kore, Aphrodite, Eileithyia), and the conservative character of the Aitolian cults. A table with the Aitolian cults is presented on p. 303. A. comments on various inscriptions and publishes two new

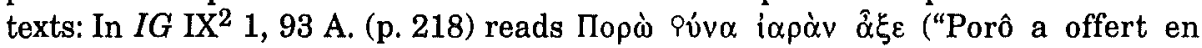
voeux la chienne sacrée", i.e. offering of a purificatory sacrifice of a dog at the sanctuary of Chrysovitsa); ed. pr. of a dedication of the statue of a theokolos to Demeter and Kore (Arsinoeia, 2nd c. BC, p. 274-275); ed. pr. of a dedication to Demeter and Kore (Kallipolis, 3rd/2nd c., p. 293-294). [AC]

11) S. Apostolakou, in $A D, 40$ B (1985) [1990], p. 301: [Note the rather rare personal name Aphrodite in a grave inscription mentioned by A. (Olous, Crete)]. [AC]

12) A. Archontidou-Argiri, in $A D, 41$ B (1986) [1990] [BE 1992, 80]: Mention of an architectonical fragment with the inscription iepòv 'A [AC]

13) A. ArLes, in Gallia Informations, 1988,2, p. 236 fig. 51 [SEG 38, 1033; $B E 1990,172]$ : Mention of an inscribed intaglio. [M. SĖvE, in $B E 1990,172$ reads the

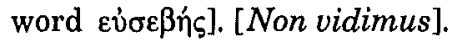

14) E. Atalay, 1986 Notion Kazilari, in KST, 9.2 (1987), p. 147-163 [SEG $38,1220 ; B E 1990,664]$ : An inscription commemorating the dedication to Artemis 
of a statue of a girl, who served as kosmophoros at the Great Klaria (Notion, imp.). [AC]

15) D. BARAG, in Ann. du 10e congrès de l'ass. int. hist. du verre, Madrid-Ségovie, 23-28 septembre 1985, Amsterdam, 1987, p. 109-116 [BE

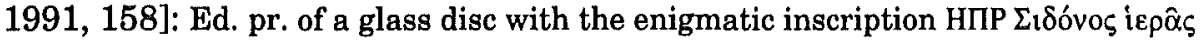

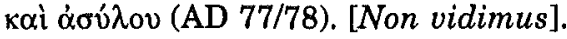

16) M. Barra Bagnasco, Locri Epizefiri. Campagne di Scavo 1988-1989 a Marasà Sud, in La Magna Grecia e il lontano occidente. Atti del 290 Convegno di Studi sulla Magna Grecia, 1989, Taranto, 1990, p. 596-605: Dedication to Aphrodite inscribed on a skyphos (Lokroi). [ES]

17) M. Barra Bagnasco, Nuovi documenti sul culto di Afrodite a Locri Epizefiri, in PP, 45 (1990), p. 42-61 [BE 1991, 689]: See infra $\mathrm{n}^{\circ} 18$.

18) M. Barra Bagnasco - G. Pugliese Carratelli, Nuova dedica locrese ad Afrodite, in $P P, 45$ (1990), p. 62-64 [BE 1991, 688]: Ed. pr. of a dedication to Aphrodite found in her sanctuary in Lokroi (5th c. BC) [cf. supra $\mathrm{n}^{\circ}$ 17]. P. suggests that the dedicant (Panta[res?]) may be a member of an eminent Geloan family. B. mentions a fragment of a roof tile with the letters IEP [perhaps $i \varepsilon \rho[\alpha$ ] ; cf. infra $\left.n^{\circ} 300.327\right]$. [AC]

19) G. BARRuol, Miroirs dédiés à Sélènè et à Aphrodite: Observations et découvertes nouvelles, in Revue Archéologique de Narbonnaise, 20 (1987), p. 415-418 [BE 1990, 161]: Ed. pr. of the setting of a mirror dedicated to

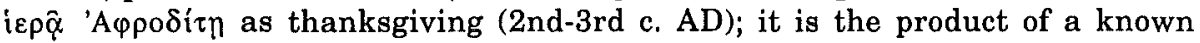
Arlesian workshop. [AC]

20) M.-F. Baslez - F. BRIquel-Chatonnet, L'inscription gréco-phénicienne de l'Asklépieion de Délos, in Semitica, 38 (1990), p. 27-38: Discussion of a bilingual dedicatory inscription of a Tyrian (Delos, I.Délos 2322); the dedicatory formula is in Phoenician, the date (reference to a priest) is in Greek. The priest is that of Asklepios in Athens; the dedication should be dated to ca. 166$156 \mathrm{BC}$ (not in the 1st c. $\mathrm{AD}$ ). The text was dedicated to a healing deity (probably Eshmoun, assimilated to Asklepios). [AC]

21) R.A. Bauslaugh, Messenian dialect and dedications of the "Methanioi", in Hesperia, 59 (1990), p. 661-668 [BE 1991, 299]: The

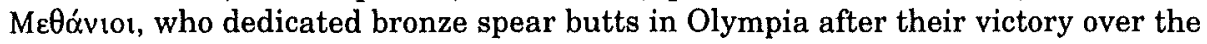
Lacedaemonians and in the precinct of Apollon Korythos near Korone after a victory over the Athenians ( $L S A G$, p. 203-204), were the Messenians, and not the

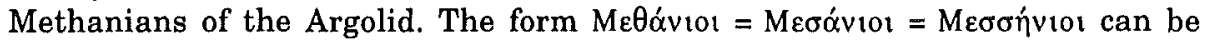
explained on dialect grounds. These dedications were probably made during the Messenian revolt in the 450 's, when the Messenians fought against the Lacedaemonians, who were supported by the Athenians. [AC]

22) E. Bernand, Dedicace à Thoueris, in ZPE, 81 (1990), p. 200-202 [BE 1991, 619]: Ed. pr. of a dedication to Thoeris Thea Megale (Oxyrhynchos?, 101-88 $\mathrm{BC}$ ); a group of theagoi (priests who carried images of gods in processions) dedicated a propylon to Thoeris/Toeris for King Ptolemy X. [AC] 
23) E. Bernand, $A$ propos d'une inscription grecque d'Eléphantine, in $Z P E, 82$ (1990), p. 179-181 [SEG 39, 1675; BE 1991, 649. 655]: Ed. pr, of a dedication to Ammon Chnoubis Theos Megistos for emperor Claudius by a priest (Elephantine, $\mathrm{AD}$ 52). B. remarks that a proskynema at Kom Ombo [EBGR 1989, 8 $\mathrm{n}^{\circ} 210$ ] is addressed to Apollon (and not to Ammon). [AC]

24) P. Bernard,Vicissitudes au gré de l'histoire d'une statue en bronze d'Héraclès entre Séleucie du Tigre et la Mésène, in JS, 1990, p. 3-68 [SEG $39,1561 ; B E 1991,126]$ : Detailed discussion of the inscribed statue of Herakles found in Seleukeia on the Tigris [EBGR 1988, 2. 141; infra $\left.\mathrm{n}^{\circ} 39.140\right]$. B. discusses the statuary typus, the transportation of statues from defeated cities to the capital of the victor, the Greek and Parthian texts inscribed on the statue, the date of the reconsecration of the statue (probably $\mathrm{AD} 151 / 2$, and not 150/1 as proposed by F. PENNACCHIETTI), the historical context of the expedition of Vologeses IV against the kingdom of Mesene, and the religious syncretism expressed in the assimilation of Herakles to Vahram (Verethragna) and of Apollon to Tir (and not Mithras, as one would expect). B, analyses the characteristics of the Iranian god Tir; he was assimilated to Apollon because of the connection of both gods to divination; both deities were also associated with the Babylonian Nabu. B. argues that the expres -

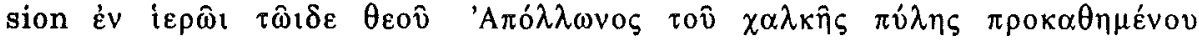
corresponds to the expression $\pi \rho \dot{\alpha} \pi$ ó $\lambda \varepsilon \omega \varsigma$, used to designate sanctuaries in front of cities and outside of the city walls. The temple of Apollon should be localised outside of the city walls, near one of the principal gates. [But see the localisation proposed by M.A. INVERNIZZI (infra $\mathrm{n}^{\circ} 140$ ) and accepted by $\mathrm{B}$. in an addendum]. B. also comments on the cult of Apollon Komaios in Seleukeia. [On the historical context see also G. MARASco, Studia Historica, Firenze, 1988, p. 77-94; D.S. POTTER, The Inscriptions on the Bronze Herakles from Mesene: Vologeses IV's War with Rome and the Date of Tacitus' Annales, in ZPE, 88 (1991), p. 277-290; G.W. BOWERSOCK, infra $\left.\mathrm{n}^{\circ} 39\right]$. [AC]

25) V. BeŠstuliev, Über die älteste Bevölkerung der Stadt Odessos, in Bulletin du Musée national de Varna, 24 (1988), p. 5-14 [SEG 38, 744]:

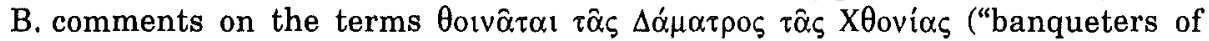

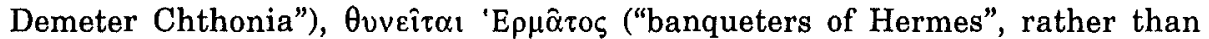

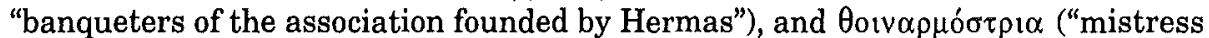
of the banquet") [cf. infra $\mathrm{n}^{\circ} 319$ ] in inscriptions of Odessos. [Non vidimus].

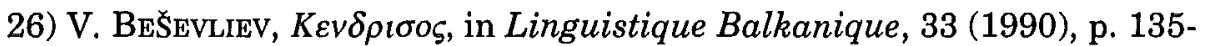
136: The place name $K \varepsilon v \delta \rho t \sigma o \varsigma$, known as an epithet of Apollon (Apollon Kendrisos or Kendreisenos) from dedicatory inscriptions of Philippoupolis, can be identified with the hill Dzendem Tepe, where the ruins of a prehistoric settlement were found. The protector deity of this place was in later times identified with

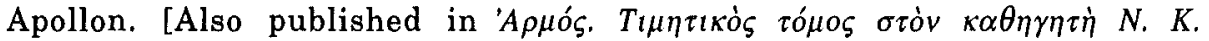

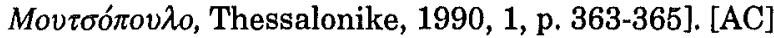

27) M. Bile - L. Brixhe - C. Dobias-Lalou - L, Dubois - R. Hodot, Bulletin de dialectologie grecque, in $R E G, 101$ (1988), p. 74-112 [SEG 38, 912]: M.B. interprets (p. $93 \mathrm{n}^{\circ} 35$ ) the word $\gamma \lambda \lambda^{\prime} \theta_{1} \alpha$ in I.Cret. III, iv 38 l. 5 (Itanos, Crete, 1st c. $\mathrm{BC}$ ) as the name of a festival for newly born children. [AC] 
28) J. Bingen - W. ClaRysse, Elkab III. Les ostraca grecs, Bruxelles, 1989 [SEG 39, 1695. 1696; $B E$ 1991, 642]: Collection of the inscriptions of Eileithyias Polis (Egypt) [cf. EBGR 1989, $8 \mathrm{n}^{\circ} 21-37$ ]; several texts (of the $\ddot{\eta} \kappa \omega$-type) commemorate visits or pilgrimages (1-4.6, Hell.; $n^{\circ} 6$ mentions the goddess Smithis); one proskynema (11, imp.). Ed. pr. of a tessera (3rd/2nd c.) with the text

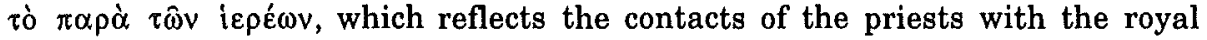
administration. [AC]

29) J. Bingen, I.ThSy. 12 (SB I 1525). Antinous et l'épistratège Gallus Marianus, in R. De Smet - H. Melaerts - C. Saerens (edd.), Studia Varia Bruxellensia ad orbem Graeco-Latinum Pertinentia, II, Leuven, 1990,

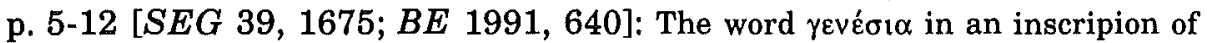
Letopolis ( $E B G R 1989,8 \mathrm{n}^{\circ} 12$ ) does not refer to Hadrian, but to the deified Antinoos. The text is inscribed on the basis of Antinoos' statue dedicated by the city on his birthday (28 November). [AC]

30) J. Bingen, Inscriptions, in H.F. Mussche - J. Bingen - J.E. Jones M. Waelkens, Thorikos IX, 1977/1982. Rapport préliminaire, Gent, 1990, p. 144-153 [BE 1991, 94]: New inscriptions from Thorikos: A decree of Thorikos concerning the leitourgia for the local dramatic festivals $(83,4$ th c. $\mathrm{BC})$; the contest of comedies is mentioned before that of tragedies; this sequence corresponds to the order these contests took place in Thorikos; a list of winners at a contest of actors (84, 4th c. BC); a text mentioning the dedication of a choregos after his victory in fulfillment of a vow (85). [AC]

31) J. BIngen, L'épigraphie grecque d'Hermonthis à Philae, in $C E, 65$ (1990), p. 129-159 [SEG 39, 1675; $B E$ 1991, 614. 646. 654]: Detailed critical review of the new corpus of A. BERNAND [EBGR 1989, 8, cf. supra $\mathrm{n}^{\circ} 23$ and infra $\mathrm{n}^{\circ} 127$. This corpus should be used in connection with B.'s article]. Among numerous new readings, corrections, and remarks on onomastics and chronology notice the remarks on the inscriptions of the nilometer at Satis $\left(\mathrm{n}^{\circ} 251, \mathrm{p} .138-139\right)$ [also see P. HEILPORN, Les nilomètres d'Éléphantine et la date de la crue 44, in $C E$, 64 (1989), p. 283-285]; on the use of the palaeography for the chronology of inscriptions (p. 141-144); the dedications $n^{\circ} 226$ (Syene) and 229 (Elephantine) are one and the same text; B. restores it as a dedication to Chnoum Theos Megistos and suggests that its probable provenance is Elephantine (p. 137); the dedication to Hera $n^{\circ} 250$ was probably not found in Elephantine, but rather in the region of Panopolis (p. 147-148); corrections to the proskynemata at Pathyris $\left(n^{\circ} 7,8,10\right.$, p. 152); the word $\gamma \varepsilon v \varepsilon \sigma^{\prime} \alpha \alpha$ in the dedication $n^{\circ} 12$ refers to the deified Antinoos

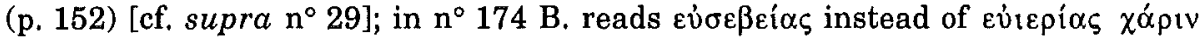
(p. 155); the woman who dedicated $n^{\circ} 195$ (Kom Ombo) calls Sarapis $\Theta \varepsilon o \varsigma$

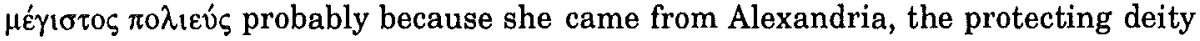
of which was Sarapis (p. 156); $n^{\circ} 199$ is not a proskynema; the text should be read

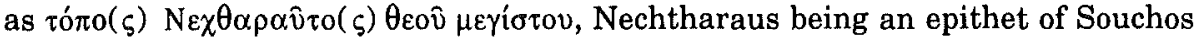
(p. 156); B. discusses various restorations in the dossier of documents concerning the privileges of the priests of Chnoum at Elephantine $n^{\circ} 244$ (p. 157-158). The corpus should also include a dedication probably found in Asphynis ( $S B$ I 1543, p. 152). [On the same corpus cf. H.J. THISSEN, Zwischen Theben und Assuan. Onomastische Anmerkungen, in $Z P E, 90$ (1992), p. 292-296.] [AC] 
32) W. BlÜMEL, Zwei neue Inschriften aus Mylasa aus der Zeit des Mausollos, in $E A, 16$ (1990), p. 29-43 [BE 1991, 208; 1992, 440]: Ed. pr. of two fragmentary inscriptions from Mylasa (m. 4th c. BC). The first text is probably a contract for the purchase of land belonging to the city Kindya by Zeus Osogollis and the city of Mylasa; the Kindyeis delimitated the sold land in the presence of delegations from at least 9 Karian cities. The new text gives for the first time the correct form of the epitheton of Zeus Osogollis, thus permitting the restoration of several other texts. The second inscription contains a list of representatives from at least 12 Karian cities and their heralds; $B$. suspects that this list belonged to a related document ( $m .4$ th $c . B C$ ). [The presence of representatives from the Karian cities as witnesses in these transactions implies that the sanctuary of Zeus Osogollis, for which the land was purchased, was the religious center of the Karian Koinon, whose members are listed in the two documents]. [AC]

33) C. Bonnet, Antipatros l'Ascalonite dévoré par un lion. Commentaire de CIS I, 115, in Semitica, 38 (1990), p. 39-47: Discussion of the bilingual (Greek-Phoenician) epitaph of Antipatros of Askalon ( $I G \mathrm{II}^{2} 8388$, late 4th c. BC); Aphrodisios, the name of Antipatros' father, is the Greek translation of a theophoric name related to Astarte (assimilated to Aphrodite). Antipatros, killed by a lion during a journey and buried in Athens, was probably the member of a theoria of Phoenician cities (Askalon, Sidon); the destination of the theoria (Athens, Delos, Delphi or a sanctuary in North Africa) is not known. [AC]

34) A. Bontini, L'attività archeologica in Basilicata, 1989, in La Magna Grecia e il lontano occidente. Atti del 29o Convegno di Studi sulla Magna Grecia, 1989, Taranto, 1990, p. 553-669: B. reports an enormous quantity of votive altars in Herakleia, some of them with traces of archaic inscriptions. Two of them, found in situ and arranged symmetrically to each other, bear the inscriptions $\triangle \mathrm{IO}$ AГ $\triangle \mathrm{AO}$ and $\triangle \mathrm{IO}$ AГOPA. The first epiklesis may be connected with Orphism (cf. Orph. fr. $236 \mathrm{Kern}$ ); the two inscriptions seen together may reflect two aspects of the same deity. Another dedicatory inscription to Zeus Aglaios (imp.) stands on a sepulcral altar found in the vicinity of the extramural sanctuary of Artemis in S. Biagio; this reveals the importance of this cult not only in the city itself but also in the country. [ES]

35) P. Bordreuil - P.-L. Gatiek, Le relief du prêtre Philôtas, in Syria, 67 (1990), p. 329-338: Ed. pr. of a bilingual (Greek-Aramaic) inscription on a relief with the representation of a priest in oriental dress offering incense in front of a statue of Herakles (unknown provenance, ca. 250-150 BC). The Greek text

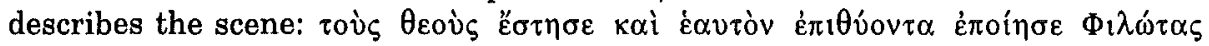
$\Phi$ i $\lambda \omega v$ os; the Aramaic text is not an exact translation of the Greek. B.-G. discuss the Semitic tradition of worshipping the gods by burning incense on a thymiaterion or a pyre. [ES]

36) B. Bonell, Katalog der Sammlung antiker Kleinkunst des Archäologischen Instituts der Universität Heidelberg. III.1. Statuetten, Gefässe und andere Gegenstände aus Metall, Mainz, 1989 [SEG 39, 1745; BE 1990, 156]: B. republishes two love-charms written on lead tablets (56, Egypt?, 1st/2nd 
c.); the sketch of a mummy, incised on one of them, probably represents Horion, the dead person implored in the charm. [AC]

37) M. Boss - P. Weiss, in E. Simon (ed.), Die Sammlung Kiseleff im Martin-von-Wagner-Museum der Universität Würzburg. Teil II. Minoische und griechische Antiken, Mainz, 1989 [BE 1990, 863]: Ed. pr. of a sling-bullet with a representation of Zeus' thunderbolt and the inscription $\Delta$ iò

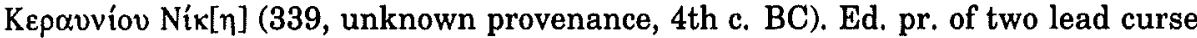
tablets. In the first defixio, one of the earliest texts of this sort, the expression $\tau \dot{\alpha} v$ $\gamma \lambda \tilde{\sigma} \sigma \alpha \nu \kappa \alpha \tau \alpha \gamma \rho \alpha \dot{\varphi} \varphi$ is addressed against a legal opponent and his witnesses or supporters (340, probably Selinous, ca. $500 \mathrm{BC}$ ); the second defixio names 15 persons (341, Selinous?, 5th c. BC). [L. DUBOIS, in BE 1990, 863 accepts the provenance from Selinous and comments on the onomastic]. [AC]

38) J. Bousquet, Review of P.A. Hansen, Carmina Epigraphica Graeca saeculi IV a Chr. n. (CEG 2), Berlin-New York, 1989, in REG, 103 (1990), p. 289-290: Various corrections to epigrams included in $C E G 2$ [EBGR 1989, 45]. B. restores the dedicatory epigram to Apollon, Artemis, and Leto in honour of a priest of $\pi \alpha \dot{v} \tau \tau \varepsilon \varsigma \theta \varepsilon o i$ (Kydonia, CEG 2, 846). [AC]

39) G.W. Bowersock, La Mésène (Maisân) antonine, in Arabie préislamique, p. 159-168 [SEG 39, 1561): B. attempts a reconstruction of the history of Mesene during the reign of Antoninus Pius in the light of the dedication of a statue of Herakles in Seleukeia on the Tigris [cf. supra $\mathrm{n}^{\circ} 24$ ]. B. points out that Herakles, who is also figured on the coins of Mesene, must have been the patron of this kingdom; the abduction of his statue from Mesene and its dedication in the sanctuary of another deity (Apollon) in Seleukeia symbolised the complete submission of this kingdom to Vologeses IV. [ES]

40) W. Brashear, A further note on the Argive votive relief of Selene, in $H T R, 83$ (1990), p. 333-340: B. reports that a relief-stele with a bust of Selene and an inscription on the underside of the base (Argos, 2nd c. AD, SEG 11, 353; 35, 272) had already been studied by A. DELATTE, in $M B, 17$ (1913), p. 321-327. Delatte regarded the stele as gnostic and the figure as the female divinity revered by the various sects of the first centuries a.C.; she was regarded as a celestial goddess of

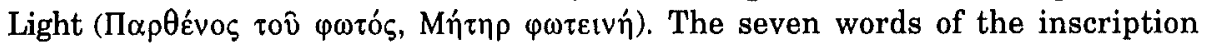
( $1 \alpha \iota \alpha, \varphi \rho \alpha \imath v \varphi \imath \rho \imath, \kappa \alpha v \omega \theta \rho \alpha, \lambda v \kappa v \sigma v v \tau \alpha, \delta \omega \delta \varepsilon \kappa \alpha \kappa \imath \sigma \tau \eta, \Sigma \alpha \beta \alpha \omega \theta, \alpha \beta \omega \theta \varepsilon \rho \sigma \alpha \varsigma$ ) were according to Delatte the secret names of the seven heavenly archons represented by the seven stars encircling the figure. $B$. supplements the bibliography on this inscription and offers an update list of parallels of these voces magicae and their interpretation [cf. supra $\mathrm{n}^{\circ}$ 239]. [AC]

41) C. Brixhe, Comparaison et langues faiblement documentées. L'exemple du phrygien et de ses voyelles longues, in La reconstruction des laryngales, Liège, 1990 , p. 58-99 [BE 1991, 561]: B. restores (p. 87) the

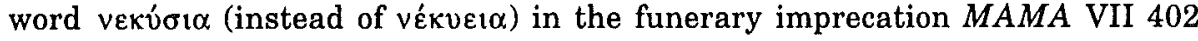
(Eastern Phrygia, imp.). [AC]

42*) H.H.J. Brouwer, Bona Dea. The Sources and a Description of the Cult (EPRO, 110), Leiden, 1989 [SEG 39, 1852]: Thorough study of the cult of 
Bona Dea, including the epigraphic testimonies; among them a Greek epitaph for the boy priest Antonios [SEG 39, 1069]. [AC]

43*) L. Bruit, Les dieux aux festins des mortels: Théoxénies et xeniai, in Entre hommes et dieux, p. 13-25 [SEG 39, 1844]: Mainly on the basis of literary sources and some epigraphical testimonia ( $S y l l^{3} 1100 \mathrm{ll}$. 61-62; LSCG $7 \mathrm{ll}$. 11-12; SEG 17, 415; L. ROBERT, OMS, II, p. 1052) B. studies the urban Theoxenia; this ritual has been conceived after the hospitality offered to distinguished foreigners (xenia), as can be inferred from the common vocabulary ( $\dot{\pi} \pi \delta \eta \mu \varepsilon \dot{\varepsilon} \omega$,

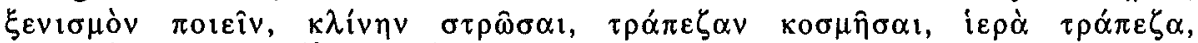
$\tau \rho \alpha \pi \varepsilon \zeta \dot{\omega} \mu \alpha \tau \alpha, \pi \alpha \rho \alpha \tau i \theta \eta \mu \mathrm{l}, \delta \alpha i v v \mu \mathrm{t})$. The theoxenia was the culminating point of the festival, following upon the sacrifice. It represents a specific form of offering to the god and at the same time a form of communication between man and the gods, reestablishing the bond which existed in the mythical age between these two worlds. [ES]

44) P. Bruneau, Deliaca VII, in $B C H, 112$ (1988), p. 569-582 [SEG 38, 762]:

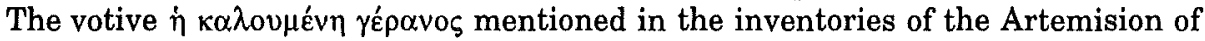
Delos probably derived its name from the dance $\gamma$ épavo $\varsigma$ performed by Theseus and his companions on Delos; this votive may be "des grains attachés à l'ormos et ...évoqueraient ainsi une sorte de chapelet rappelant la farandole de danseurs se tenant par le main". If this dance was performed in the autumn, its name can be explained by the cry of the homonymous bird in that season. [AC]

45) G.R. Bugh, The Theseia in late Hellenistic Athens, in ZPE, 83 (1990), p. 20-37 [BE 1991, 170]: Detailed discussion of the athletic programme of the Theseia in Hellenistic Athens on the basis of the 2nd-c. BC honorific decrees for the agonothetai. The epigraphic evidence for the expenses for the Theseia shows that it had become one of the major festivals by the end of the classical period and was celebrated annually on the 8th Pyanopsion. It is, however, not certain that the Theseia included a horse race already in classical times. The 2nd-c. texts record not the annual Theseia but a new pentaeteric festival, which was probably founded in 165/4. Its athletic programme included competitions for trumpeters and heralds, military reviews ( $\varepsilon \dot{v} \alpha v \delta \rho i \alpha, \varepsilon v j o \pi \lambda i \alpha$ ), torch races, gymnastic and equestrian competitions. $B$. focuses especially on the age-classes of the competitors and the chronology of the documents. [Cf. the remarks of P. GAUTHIER, in $B E 1991,170$ ]. [AC]

46) W. Burkert, Apollon of Didyma and Olbia, in VDI, 1990.2, p. 155160: Discussion of the bone tablet from Berezan mentioning Apollon Didymaios (late 6th c. BC) [SEG 36,694; cf. $E B G R$ 1987, 32] and containing one of the few authentic oracles of the 6th c. BC. According to the first editor A.S. RUSAJEVA [ $B E$ 1990,549 ] the numbers 7-70-700-7000 in this oracle symbolize the demographic development of Olbia; the text indicated the transition from the cult of Apollon Iatros to that of Apollon Delphinios. B. argues that the one cult did not subsitute the other; the two cults amalgamated. B. interprets the text as an oracle for the future of Olbia (cf. AETIUS II 32,5 on the great cycle of 7777 years): The city is compared in the first 7 years with a weak wolf and in the next 70 years with a fearful lion; 700 years are characterised by the properties of Apollon Iatros, while the following 7000 years are the era of the wise dolphin (cf. Apollon Delphinios); 7 is the sacred 
number of Apollon. Similarly, the future story of Rome is presented by VERGILIUS (Aen. I 261-282) as a sequence of $3+30+300+$ infinite number of years. B. finds numerous parallels for the sequence of four periods in the Oriental and Greek literature (Daniel 2 and 7, Hesiod, Aristophanes' Equites). The last verses of the

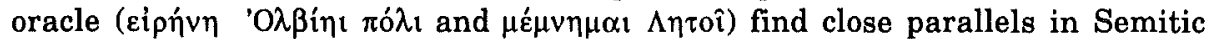
expressions. The new text presents an important evidence for the way oracles were produced in archaic Didyma; it also indicates the diffusion of Oriental mantic practices in the archaic Greek world. [AC]

47) O. CAllot, Failaka à l'époque hellénistique, in Arabie préislamique, p. 127-144 [SEG 39, 1560]: C. discusses the inscription from Ikaros/Failaka concerning the sanctuary of Soteira [cf. infra $\mathrm{n}^{\circ}$ 249], which he dates to the reign of Antiochos III (203/2 BC) rather than Seleukos II (239 BC). The context of this inscription refers to the relocation of the sanctuary of Artemis Soteira and the establishment of athletic and musical contests. According to $C$. the text evokes the status of asylum for this sanctuary. [ES]

48) G. Casadio, Sincretismo magico ellenistico o nuova religione? $A$ proposito di un recente studio sui testi magici greci, in Orpheus, 11 (1990), p. 117-125: In his review of a recent study of Meliouchos (C. HARRAUER, Meliouchos. Studien zur Entwicklung religiöser Vorstellungen in griechischen synkretischen Zaubertexten, Wien, 1987) C. discusses briefly (p. 122 note 8 ) the

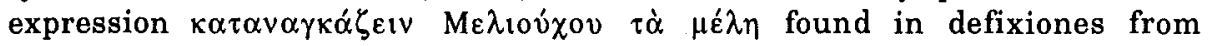
Alexandria and Cyprus (22,32 and 27,19 Audollent; Harrauer proposed the

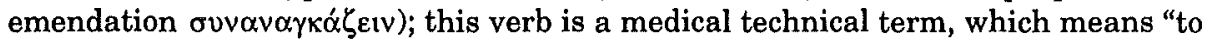
put into their place dislocated or fractured limbs". [AC]

49) M. Casewitz, Beuglants et muets, in Hommage à G. Roux, p. 185-192

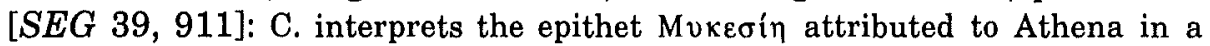
dedication found in Thasos ( $B C H, 89,1965$, p. 447 n. 5) as the "moing Athena"; this epithet is related to the stem $\mu v \mathrm{k}$ - ("to roar", "to moo") and refers to Athena as the patroness of the cows. [ES]

50) P. Castrén, The post-Herulian revival of Athens, in Greek Renaissance, p. 45-49: Discussion of the epigraphic and literary evidence for the relations of the scholars of the Neoplatonic School in the 5th c. AD (esp. Plutarchos) to pagan cults (cults of Asklepios and Dionysos, Orphism, celebration of the Panathenaic festival). [AC]

51) H.W. Catling, A sanctuary of Zeus Messapeus: Excavations at Aphyssou, Tsakona, 1989, in ABSA, 85 (1990), p. 15-35: Report on the excavations conducted at a shrine in Lakonia (7th-4th c. BC, 3rd-4th c. AD), where a cup dedicated to Zeus Messapios had been found [ $E B G R$ 1989, 18). New finds of stamped tiles naming Zeus Messapeus definitely prove the existence of his sanctuary at Tsakona. The relation of this shrine to another sanctuary of Zeus Messapeus at Anthochori is still not clear. [AC]

52) O. Cavallier, in Revue du Louvre, 6 (1990), p. 443-454 [BE 1991, 21]: An altar dedicated to Pan and Apollon in fulfillment of a vow (with representation of the two gods, Attica). [Non vidimus. The same text in Sotheby's Catalogue, London, 
Antiquities, Monday/Tuesday 10th/11th July 1989, p. 70 n 192 (SEG 39, 1725)]. [AC]

53) A. Chaniotis, Drei kleinasiatische Inschriften zur griechischen Religion, in $E A, 15$ (1990), p. 127-134 [SEG 37, 1001. 1012. 1211; BE 1991, 465. 505. 599]: 1) Discussion of the 'confession inscription' $E B G R$ 1987, 87 (Lydia,

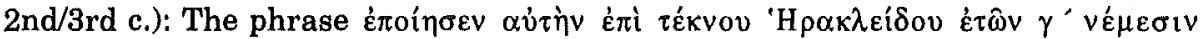

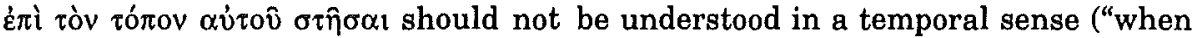
her child was thirteen years old"); it refers to the way the sinner was forced to make her confession ("through the punishment of her 13 years old son"). The

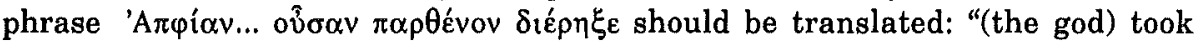
the virginity of Apphia, who was (still) a virgin" (and not "he destroyed her"). The treatment of a hyacinth-stone (burning, covering with a linen-cloth) indicates magic; numerous parallels can be found in the Lithic poems and the magical papyri. Apphia, who had stolen the hyacinth-stone, was probably punished not just for stealing ( $\tau \grave{\eta} v \kappa \lambda \dot{\varepsilon} \psi \alpha \sigma \alpha \nu$ ), but also for performing magic ( $\kappa \alpha \hat{\imath} \tau o \hat{v} \tau o$ $\left.\pi 0 ı \sigma^{\prime} \sigma \alpha \sigma \alpha v\right)$. [On this text see also infra $\mathrm{n}^{\circ} 125$.] 2) The name of the goddess Nemesis should be restored in an inscription from Karallia (AD 172-175); the statue of Nemesis was dedicated by the high-priestess in the Caesaraeum (perhaps in connection with the war against the usurpator Avidius Cassius). [Cf. $E B G R$ 1987, 77]. 3) A dedicatory pillar in Hadrianoi (1st/2nd c.) may be a dedication to [Zeus] Dagoutenos. [Cf. $E B G R$ 1987, 104). [But see the objection of C. BRIXHE - A.

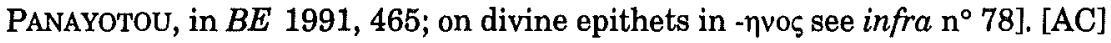

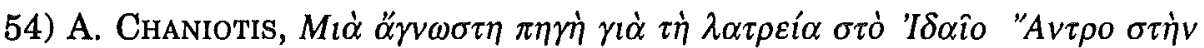

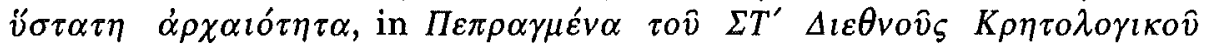

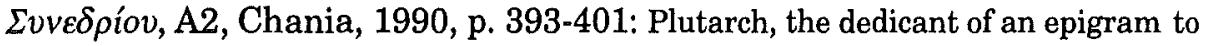
Hera in Samos, is identified with a friend of Julian [cf. $E B G R$ 1987, 17; SEG 37, 730]. In his epigram Plutarch underlines the fact that he became governor of the Provincia Insularum after he had visited the Idaean cave on Crete and had offered a sacrifice to Zeus; this is the latest testimony for the cult in the Idaean cave (ca. AD 361-363). According to the literary tradition, the Idaean cave was the center of a mystery cult of Orphic inspiration. Some expressions used in Plutarch's poem find close parallels in Orphic texts, thus implying that Plutarch was initiated in the local

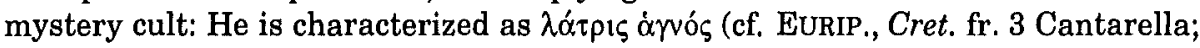

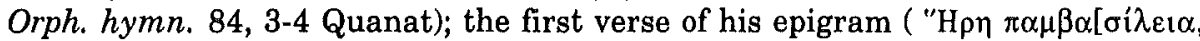

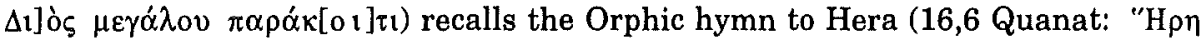

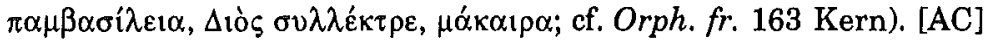

55) P. Charneux, En relisant les décrets argiens, in $B C H, 114$ (1990), p. 395-415: Study of the structure and formulas of the Argive decrees, with remarks on the Argive calendar (p. 399-401), the honorary title 'theorodokos of Zeus of Nemea and Hera' (p. 407-408), and the proclamation of honours during Argive festivals (Nemeia, Heraia). [AC]

56) L. Chatziangelakis, in $A D, 40$ B1 (1985) [1990], p. 195: Mention of a dedication to Zeus Homoloios found in Metropolis (Karditsa); it is the first attestation of the cult in this area. [AC] 
57) K.A. Christensen, The Theseion: A slave refuge at Athens, in $A J A H$, 9 (1984) [1990], p. 23-32: C. studies the literary evidence for the use of the Athenian Theseion as a refuge of slaves, who hoped to be resold. In the cases, in which the slave was resold against his master's will, a prosecution of his master on a charge of $i \beta p i \zeta \varepsilon i v$ may have taken place. C. recognizes an analogous procedure in the mystery inscription of Andania ( $L S C G$ 65), which provides for a trial, presided over by the priest, for runaway slaves from Messene. With these measures the cities managed to define and control the institution of temple asylum as regards the slaves. [AC]

58) Christie's Sales Catalogue, London, Antiquities, 12nd December $1989, \mathrm{n}^{\circ} 255$ [SEG 39, 1727]: Dedication to Zeus Keraunios (unknown provenance, 2 nd c. $\mathrm{AD}$ ). [Non vidimus].

59) P. Chrysostomou, in $A D, 39$ B (1984) [1989], p. 264 [SEG 39, 620; BE 1991, 394]: Mention of a relief with a representation of an eagle, dedicated in fulfillment of a vow ( HATZOPOULOS, in $B E$ 1991, 394 regards it as a dedication to Zeus Hypsistos.] [AC]

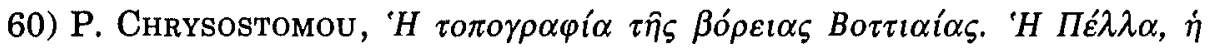

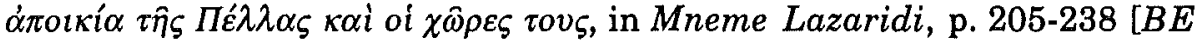
1990, 461]: Topographical survey of the Northern Bottiaia (Macedonia); C. mentions two unpublished dedications to Zeus Hypsistos (p. 211, Anidro Giannitson; p. 230, Agrosikia) [ = supra $\mathrm{n}^{\circ}$ 59]. [AC]

61*) M. CICERoni, Iside protettrice della navigazione. La testimonianza delle lucerne a forma di barca, in Anathema, p. 793-801: Presentation of a series of boat-shaped lamps with representations of Egyptian deities; some of them

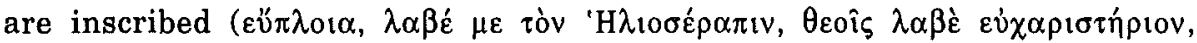
$\kappa \alpha \tau \dot{\alpha} \pi \lambda$ ov etc.). These objects can be associated with the cult of Isis as protector of navigation. Not all of them were dedications; a domestic or funeral use cannot be excluded. [AC]

62*) M. Cipriani - A.M. Ardovino, Il culto di Demetra nella chora Pestana, in Anathema, p. 339-351: Presentation of the sanctuary of Demeter at San Nicola di Albanella (Poseidonia/Paestum, 6th-4th c.); discussion of the dedications (esp. terracottas) and sacrificial offerings. Notice three inscriptions on silver plates dedicated to Demeter and Kore (of the type $\tau \eta_{\varsigma} \theta \varepsilon o v$ eiłu íepóv). [AC]

63) K. Clinton, The Treasury of the Two Goddesses and Eleusinian construction in the Classical period, in Praktika Klas. Arch., 4, p. 3336: C. reviews the contradictory information about the construction of the Telesterion at Eleusis. The decree about the establishment of the epistatai of Eleusis ( $I G \mathrm{I}^{3} 32$ ) should be dated to $432 / 1$ [cf. infra $\mathrm{n}^{\circ} 234$ ]; the Telesterion was built in the 440 's by Koroibos, while Iktinos was probably involved at a planning stage. The work was continued by Metagenes and Xenokles. This building was part of Perikles' plan to display Athens as the center of Hellenic civilization. [AC]

64) K. Clinton, Hadrian's contribution to the renaissance of Eleusis, in Greek Renaissance, p. 56-68 [BE 1991, 280]: Detailed discussion of the literary, archaeological, and epigraphic testimonies for Hadrian's relation to the 
sanctuary of Eleusis. Hadrian had been initiated into the mysteries before he was an emperor; during his visits to Athens as an emperor he merely attendend the mysteries (IG II ${ }^{2} 3620$ ). From the fact that the Panhellenion, which was founded by Hadrian, dedicated the First Fruits to Eleusis $\left(I G \mathrm{II}^{2} 2957-2958\right) \mathrm{C}$. infers that this council may have taken over some aspects of the sanctuary administration. The image of Hadrian on some of his coins adopts features of Ploutos (cf. $I G \mathrm{II}^{2} 3375$ ). Antinoos, who had also been initiated, was assimilated to Asklepios; contests were established in his honour at Eleusis. The construction activity carried out under Hadrian includes the Propylaea. [AC]

65*) W.R. Connor, Seized by the Nymphs: Nympholepsy and symbolic expression in classical Greece, in ClAnt, 7 (1988), p. 155-189 [SEG 38, 2728]: Investigation of the belief that an individual was seized by the nymphs as well as of other forms of possession in Greek culture; special discussion of the inscriptions found in the cave near Pharsalos dedicated by Pantalkes to the Nymphs, Pan, Hermes, Apollon, Hekate, Chiron, Asklepios, and Hygieia (SEG 16, 377-378), the cave of the Nymphs at Kafizin (Cyprus, T.B. MitForD, The Nymphaeum of Kafizin, Berlin, 1980), and the cave of the Therean Archedamos at Vari (Attica, IG $\mathrm{I}^{2} 784-788$, with a thorough study of the topography of this shrine). It was believed that the nympholeptos had a special contact with what was holy, consequently also with the power that came from the divine (including prophetical properties). [AC]

66*) W.R. Connor, City Dionysia and Athenian democracy, in $C \& M, 40$ (1989), p. 7-32 [SEG 39, 190. 862]: C. shows how inconclusive the evidence for the alleged establishment of the City Dionysia under Peisistratos is and offers an alternative reconstruction of the festival's development: Eleutherai was incorporated into the Athenian state after the fall of Peisistratos (ca. 506-501); the introduction of the cult of Dionysos Eleuthereus at the same time did not only underline the annexation of the Boeotian town, but was also "a celebration of the success of the system that had replaced the Peisistratid regime"; the City Dionysia were inaugurated ca. 501. This view is strengthened by various aspects of the City Dionysia, which can be associated with the new civic order and the ideas of freedom and democracy. In Appendix I C. discusses the archaeological evidence for the cult of Dionysus Eleuthereus in Athens. In Appendix II he shows that the generally accepted idea that Thespis produced a play in the City Dionysia in the 530 's is based on restorations and conjectures in the Marmor Parium, which contradict the testimony of those who had seen the inscription before it was severely damaged in the 17 th c.; thus the Marmor Parium does not prove that the City Dionysia existed in Peisistratid Athens. C. suggests that Thespis performed his plays in rural Attica. [AC]

67) T. Consten, Caesarea Germanice, in EA, 15 (1990), p. 19-48 [BE 1991, 575]: Presentation of the history, institutions, and inscriptions of Kaisareia Germanike (Bithynia). Ed. pr. of an agonistic inscription (2nd c. AD?); the hieronikes Tatianos had won the dolichos race at the following contests: Sebasta of Neapolis, Augusteia and Traianeia in Pergamon, Hadrianeia in Ephesos, the provincial agon of Bithynia, and Hadriana Olympia in Kyzikos. [AC] 
68) L. Criscuolo, Un epigrafe augurale su testa di coccodrillo, in Aegyptus, 70 (1990), p. 87-88 [BE 1991, 625]: Dedication of a stucco-head of a

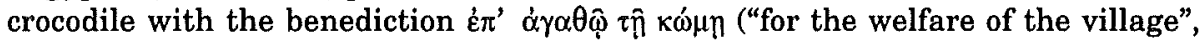
area of Fayum?, 1st c. AD). [AC]

69) R.W. DANIEL - P.J. SiJPEISTEIJN, Remarks on a magical inscription, in $J W I, 51$ (1988), p. 169 [SEG 38, 1924]: D.-S. restore the expression $\delta \varepsilon \xi_{1 \alpha i}$

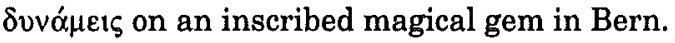

70) S. De CARo, Un graffito ed altre testimonianze del culto della Magna Mater nella villa romana di Oplontis, in R.I. CURTIS (ed.), Studia Pompeiana \& Classica in Honor of W.F. Jasshemski, New Rochelle, 1988, I, p. 89-96 [SEG 38, 1001]: Ed. pr. of a graffito on the wall of the Villa of

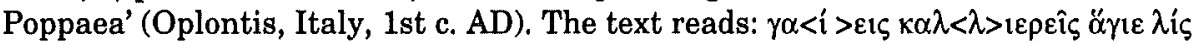
("you are happy, you give propitious omens, sacred lion"; notice the Homeric forms). The sacred lion is associated with the cult of Magna Mater. This text may derive from a ritual text concerning her cult. Representations of Attis were also found in the same area of the villa. [AC]

71) J. DE LA Genière, Le sanctuaire d'Apollon à Claros: nouvelles découvertes, in $R E G, 103$ (1990), p. 95-110 [BE 1991, 476]: Review of the previous excavations at the sanctuary of Apollon in Klaros and presentation of the recent work, concerning mainly the topography of the sanctuary, the chronology of its monuments and the relation between the temples of Apollon and Artemis. G. mentions three new inscriptions (p. 102, 105-106): a dedication made by a priest and two decrees of Kolophon found near the altar of Artemis. The archaeological finds include an altar of the 3rd c. BC near the great altar of Apollon and votives of the 7th-6th c., which illuminate the early phase of the sanctuary; there is so far no indication that the sanctuary existed already in Mycenaean times. [AC]

72*) J.-M. Dentzer, Le sanctuaire syrien, in Syrie, p. 297-322: Study of the general characteristics of Syrian sanctuaries. D. discusses the basic elements of sanctuaries (temple, propylon, altar, banquet rooms, shrines, 'theatre', cisterns, dedications); the impact of local traditions; the further development of sanctuaries in the Hellenistic age (especially the new regular geometric forms in architecture); the rôle of sanctuaries in economy (sacred land, trade, banking activity), society (cults of certain clans, professional associations), and politics (gods regarded as poliouchoi, rôle of the sanctuaries as link between the political power and the population). [AC]

73) M.P.J. Dillon, 'The house of the Thebans' (FD iii.1 357-358) and accomodation for Greek pilgrims, in ZPE, 83 (1990), p. 64-88: F.Delphes III.1 357-358 (1. 3rd. c. BC) concerns the protest of Theban ambassadors (theoroi?) to Delphi for the inadequate hospitality provided to them by a certain Kraton. $D$. argues that the 'House of the Thebans' referred to in these inscriptions was a property of Kraton, who probably served as the theorodokos of Thebes in Delphi. The measures taken against Kraton by the amphictionic council and Delphi, in order to undo the damage done to the Theban-Delphic relations reveal the significance of the position occupied by theorodokoi. According to $\mathrm{D}$. the three houses mentioned in the context of an Andrian theoria to Delphi (CID 7) had a 
similar function as the 'House of the Thebans'. D. discusses the hereditary position and the high social status of theorodokoi and reviews the scanty evidence for the accomodation of common pilgrims. They usually stayed in tents (cf. especially the

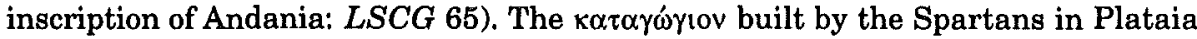
(THUC. III 68,3) might have been used for the accomodation of important dignitaries. Although the sanctuaries had dinning-rooms, they lacked permanent constructions for the accomodation of pilgrims. [On the use of tents see also LSCG

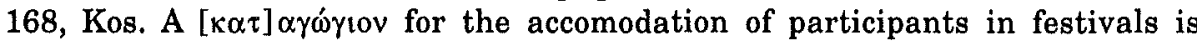
probably mentioned in a treaty between Hierapytna and Lato on Crete: $S E G 26$, 1049 Z. 50]. [AC]

74*) A.A. Donohue, Xoana and the Origins of Greek Sculpture, Atlanta, 1988 [BE 1991, 118]: D.'s thorough study of the use of the word Foovov in the literary and epigraphic sources shows that the word usually does not mean a primitive wooden cult image, but has a variety of meanings (splendid image of a god, dedication, image in a temple); thus, this term alone cannot prove the existence of primitive, wooden cult images. The book includes an extensive appendix with the literary (p. 237-371), papyrological (p. 372-378), and epigraphic (p. 379-403) testimonia. [Cf. the remarks of M. SÈVE, in $B E$ 1991, 118]. [AC]

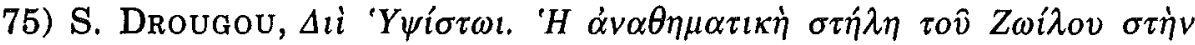

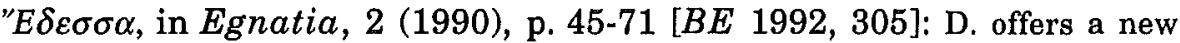
restoration of the stele of Zoilos dedicated to Zeus Hypsistos i $\pi \dot{\varepsilon} \rho \tau \hat{\omega} v \pi \alpha \imath \delta i$ í (Edessa); the stele, which supported a votive offering, is to be dated in the early 1st c. BC; thus, it is not the earliest testimony for the cult of Zeus Hypsistos in Macedonia. D. discusses the relief decoration (garlands of oak-leaves, eagle, oxhead, griffins), the evidence for the cult of Zeus Hypsistos in Macedonia, and its relation to the cult of Dionysos. [Cf. the remarks of M.B. HATZOPOULOS, in $B E$ 1992, 305; on the cult of Zeus Hypsistos in Macedonia cf. supra $\mathrm{n}^{\circ}$ 59-60]. [AC]

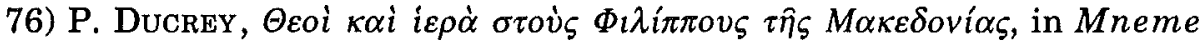
Lazaridi, p. 551-557: See EBGR 1988, 44.

77) K.M.B. Dunbabin, Ipsa deae vestigia: Footprints divine and human on Graeco-Roman monuments, in JRA, 3 (1990), p. 85-109 [BE 1992, 425]: An interesting study of the representation of footprints in sanctuaries (especially on mosaics). D. demonstrates that a variety of reasons can explain this practice. Beside the footprints of dedicants, immortalising their presence in the sanctuary, some footprints can be interpreted as footprints of deities (" $i \chi \vee \eta \theta \varepsilon \circ \hat{v}$, mostly of Isis and Sarapis) expressing their epiphany. D. makes ample use of inscriptions (EPRO, 49; TAM III.1, 32; I.Stratonikeia 248; I.Pergamon 336). The bronze soles dedicated to Apollon Korkyraios (M. GUARDUCCI, Epigrafia graeca, III, Roma, 1974, p. 72) may be representations of the god's footprints (p. 95 note 49). [AC]

78) I. Duridanov, Probleme der thrakischen Sprache III, in Linguistique balkanique, 32 (1989), p. 85-112 [SEG 39, 642]: Collection and discussion of 86

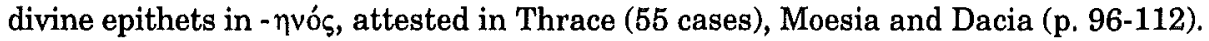
67 of these epithets derive from place names. The deities called with epitheta of this type are most often Apollon (23 cases), the Thracian hero (22 cases), Asklepios (14), Hera (12), and Zeus (9); other deities are Aphrodite, Artemis, Dionysos, Hephaistos, 
Herakles, Hygieia, Meter Theon, the Nymphs, Sabazios, Telesphoros, and Juppiter. [AC]

79) S. Durugönül, Die Felsreliefs im Rauhen Kilikien, Oxford, 1989 [BE 1992, 536]: Study of the rock-cut reliefs in Kilikia Tracheia (2nd c. BC-3rd c. AD), including a presentation of the inscriptions (no new texts). 3 texts (1.2.4) from a sanctuary of Hermes (Yapilikaya) name the eponymous priests; one of the texts records the dedication of a propylon to Hermes and the Demos (4). D. publishes two reliefs dedicated to Athena Krisoa Oreia (42; cf. p. 128-137) [EBGR 1987, 30; $B E 1989,122]$ and Hermes (44, cf. p. 142-143, dedicated by two priests), and a relief representing Juppiter Dolichenus (43, cf. p. 137-142). Several grave inscriptions contain funerary imprecations and prohibitions (19. 25. 38); in some cases the fine was to be paid to sanctuaries (19. 25). The themes represented on the reliefs (banquet, warriors, families, mourners, sacrifice), reveal a fusion of indigenous and classical Greek elements. [AC]

80) N. Ehrhardt, Apollon Ietros. Ein verschollener Gott Ioniens?, in $M D A I(I), 39$ (1989), p. 115-122 [SEG 39, 1851; BE 1991, 446]: The cult of Apollon Ietros is attested only in Milesian colonies; M.P. NILSSON (followed by F. GRAF) had suggested that the cult originated in Ionia, where it disappeared in later times, but other scholars regarded Apollon Iatros a local deity of the Black Sea. According to E. the theophoric names related to Apollon Iatros have approximately the same distribution as the theophoric names related to Apollon Oulios (on the latter see now $E B G R$ 1988, 111], thus supporting the Ionian (probably Milesian) origin of the cult. This view can be strengthened by a coin of Apollonia Pontike which names Apollon Iatros; the representation of laurel-branches on this coin is related to the religius traditions of Didyma and reflects the cult of Apollon as a purificatory deity. Apollon Iatros was probably a god of purifications with a significant rôle in the citizen-life of the Ionian cities. The disappearance of his cult may be due to the diffusion of Asklepios' cult in the 5th c. BC. [AC]

81) N. EHRHARDT, Eine neue Grabinschrift aus Iconium, in ZPE, 81 (1990), p. 185-188 [BE 1991, 606]: A funerary altar is mentioned in the epitaph of a slave and his family (Ikonion, 1st/2nd c.). [AC]

82) S. ELwyn, The recognition decrees for the Delphian Soteria and the date of Smyrna's inviolability, in JHS, 110 (1990), p. 177-180: A close study of the wording in the recognition decrees for the Soteria of Delphi [G. Nachtergael, Les Galates en Grèce et les Soteria de Delphes, Bruxelles, 1977, $\left.n^{0 s} 21-27\right]$ shows the clear differences of the decree of Smyrna $\left(n^{\circ} 25\right)$ from the other documents; $E$. argues that this decree was not issued in response to the first Aitolian initiative for the recognition of the Soteria (ca. 246/5), but after the grant of asylia to Smyrna by Seleukos II (OGIS 229, 244/3?) and probably on the announcement of the 2nd Soteria (241 BC). [AC]

83) H. EngelmanN, Ephesische Inschriften, in $Z P E, 84$ (1990), p. 89-94 [BE 1991, 62. 484]: The fragments I.Ephesos 1168 and 4101b belong together. This inscription contains a list of victors at the contest of doctors at the Great Asklepieia of Ephesos (AD 153/4); the text names the priest of Asklepios, the Asiarch, the agonothetes, and the archon of the association of doctors. E. restores I.Ephesos 
859 a as an honorific inscription for a Caesaris libertus, who donated to the conventus civium Romanorum in Ephesos an amount of money; his donation should finance an annual sacrifice to Artemis and Dea Roma. The text shows that

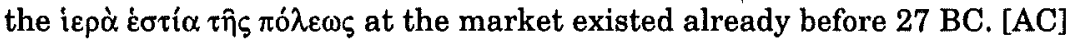

84) R. Étienne, Ténos II. Ténos et les Cyclades du milieu du IVe siècle av. J.-C. au milieu du IIIe siècle ap. J.-C., Paris, 1990 [BE 1991, 430-434]: A treatise of the history, the institutions, the economy and the society of Tenos, based mainly on the inscriptions. Newly edited inscriptions: 1) An honorary decree of the patra of Androklides (p. 37-39), set up in the sanctuary of a female deity with a short name (Hera?, Kore?); this sanctuary was not attested. 2) An honorary decree for a benefactor (p. 268), mentioning the sanctuary of Poseidon and

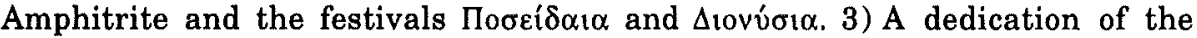
archon and the $\dot{\alpha} \rho \chi i \zeta$ after their term of office. The archis was also priestess $\delta 1 \dot{\alpha}$ $\gamma$ źvovৎ of Amphitrite (p. 146). 4) A fragment perhaps of a regulation concerning the hieropoioi (p. 36). Of special interest are also E.'s remarks on the lex sacra LSCG Suppl. 48; based on the evidence of a new inscription $E$. argues that this text regulated the membership in a phratry or rather in a patra (p. 37-42). [ES]

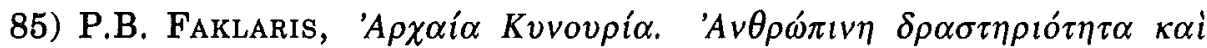
$\pi \varepsilon \rho 1 \beta \alpha \lambda^{2} \lambda o v$, Athens, 1990: Survey of the cults and sanctuaries in Kynouria (Arkadia, p. 173-200). Sanctuary of Apollon Tyritas (Tyros, p. 173-178): The sanctuary was in use in the 8th-4th c. BC; several inscriptions on clay and bronze dedications name Apollon Tyritas and Apollon Pythaieus. Sanctuary of Maleatas (Kosmas, p. 178-183): The few dedicatory inscriptions name Maleatas and (Apollon) Pythaieus. F. suggests that $I G$ V 1, 929 (dedicatory inscription to Maleatas) was found here and not in Leonideion. The sanctuary was in use from the 8th c. BC and throughout the classical period. Sanctuary of Parparos (Agios Ioannis Astrous, p. 183-185): On a bronze statuette of a bull F. reads the name of the

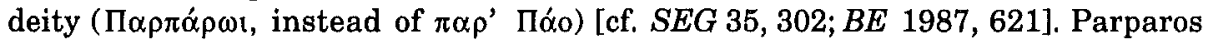
can be associated with the mountain Parparos and the Spartan festival Parparonia. Sanctuary of Apollon (Elliniko Astrous, p. 185-192): From the representation of the Apollinic trias on a clay tablet F. infers that Apollon was the deity worshipped in this sanctuary, which was established in the 4th c. BC. A stamped tile names the community of Eua, where an important Asklepieion flourished in Hellenistic times. Sanctuary of Polemokrates (Eua, p. 192-193): The main deity worshipped in the Asklepieion of Eua was Polemokrates, son of Machaon. The hero is probably mentioned in the dedicatory inscription on a relief representing a funerary banquet. Hermai (Agios Petros, p. 193-195): Three large heaps of stones have been identified with the site Hermai mentioned by PAUSANIAS (II 38,7); Hermes is

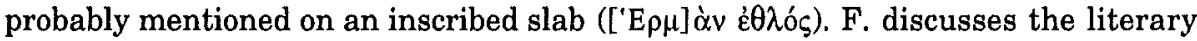
evidence for the cults of Asklepios, Achilleus, Dionysos, Ino, the Dioskouroi, and Athena in Prasiai and Poseidon Genesios at Genethlion (p. 195-200). [On some topographical problems concerning Thyrea and Eua cf. W.K. PRITCHETT, Studies in Ancient Topography. Part VI, Berkeley-Los Angeles, 1989, p. 87-88]. [AC]

86*) C.A. Faraone, An accusation of magic in Classical Athens (Ar. Wasps 946-948), in TAPhA, 119 (1989), p. 149-160 [SEG 37, 221]: Discussion of the use of black magic in judiciary context in classical Athens with reference to 
Aristophanes (Wasps, vv. 946-948) and Attic defixiones (p. 155-158). [For new Attic defixiones in judiciary context see infra $\mathrm{n}^{\circ} 148.321$ ]. [AC]

87) A. FARID, Die Denkmäler des Parthenios, des Verwalters der Isis von Koptos, in $M D A I(K), 44$ (1988), p. 13-65 [SEG 38, 1834; BE 1990, 827]: Collection and discussion of the hieroglyphic, demotic, and Greek inscriptions recording the activity (esp. building activity and dedications) of Parthenios,

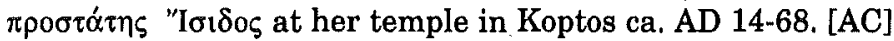

88) J. Faucounau, L’inscription bilingue gréco-sedétique de Séleukeia, in $A C, 59$ (1990), p. 166-171: New linguistic discussion of the bilingual dedication from Seleukeia $[E B G R 1989,128]$. F. presents basically the same text and interpretation as C. BRIXHE and G. NEUMANN. [AC]

89) D. Fishwick, Votive offerings to the emperor?, in ZPE, 80 (1990), p. 121-130 [BE 1991, 570]: According to A.D. NocK prayers, sacrifices, and votive offerings were not part of the imperial cult. In view of some Greek inscriptions S.R.F. PRICE has supported the opposite case. Pointing at the equivocal character of the epigraphic evidence F. challenges PRICE's view and concludes: "The living emperor was not seen as a personal god of saving or healing to whom one turned at times of crisis or afflictions. The deified emperor was another matter..., though here it seems to have been the practice to pay vows to him only in association with other deities of the Roman state". [Most of the inscriptions F. discusses are indeed equivocal. But at least in two cases F.'s scepsis is exaggerated. In the case of $S E G 2$,

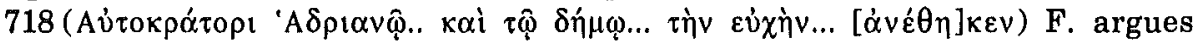
that the vow was not addressed to Hadrian, but to Zeus, since the dedicant was Zeus' priest; $\alpha$ vं oxpótopt means "in honour of the emperor". However, the Greek text does not leave any doubt that the dedication in fulfillment of a vow was addressed to Hadrian. The second addressee of the dedication was the Demos; the cult of the Demos is often attested in association with the imperual cult: see e.g.

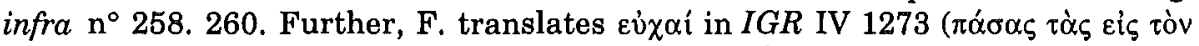

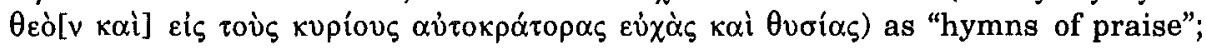
but in this standard expression eưn can only mean "prayer". It is true that the living emperors can not be compared with the traditional gods, but this does not exclude the possibility of prayers and votive offerings, also attested for the Hellenistic ruler cult: see e.g. EBGR 1989, 77]. [AC]

90) S. Follet, Contribution à la chronologie attique du premier siècle de notre ère, in Greek Renaissance, p. 37-44 [SEG 39, 212]: Restoration of $I G$ $\mathrm{II}^{2} 3174$, which records building activity at the Asklepieion on the Akropolis (cf. IG $\mathrm{II}^{2}$ 1046); the text should be dated to 51/50 BC. [AC]

91) S. Follet, Bulletin épigraphique. Rapports avec la littérature, in

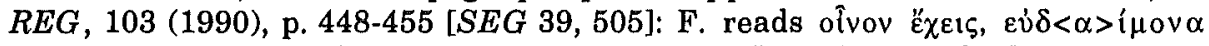
$\tau \imath \mu<\alpha>v$ ("tu possèdes du vin, bienheureux privilège") in the new Orphic text from Thessaly [cf. infra $\mathbf{n}^{\circ} 107.113 .149 .276$ ]. [AC]

92) B. Fórsen - E. Sironen, Zur Symbolik von dargestellten Händen, in Arctos, 23 (1989), p. 55-66 [SEG 39, 233. 387. 1850]: F.-S. review the evidence for the dedication of representations of arms and hands (based on F.T. VAN STRATEN, Gifts for the gods, in Faith, Hope, and Worship, Leiden, 1981, p. 65-151). 
They offer some bibliographical contributions and critical remarks on the reading of several dedicatory inscriptions. While the representations of arms can be interpreted as 'anatomical votives', the representations of hands (either of a single hand or of a pair of hands) can be interpreted in various ways: They may be apotropaic symbols, representations of sick hands, or references to the invocation of a god. [AC]

93) B. Fónsen, A rediscovered dedication to Zeus Hypsistos, EM 3221, in Tyche, 5 (1990), p. 9-12 [BE 1991, 127]: The inscribed anatomical votive EM 3221 (National Museum of Athens) depicting the dorsal part of a male body can be identified with one of the dedications found by L. CURTIUS in 1862 at the sanctuary of Zeus Hypsistos in Pnyx (1st/2nd c. AD). F. restores the dedicatory inscription addressed to Hypsistos (sc. Zeus). [AC]

94*) G. Fowden, Religious developments in late Roman Lycia: Topographical preliminaries, in Пoเкi $\lambda \alpha$, p. 343-372 [BE 1992, 459]: F. studies the rôle of the geographical factor in the relations between pagan religion and Christianity in the case of Lykia (transhumance, importance of the sea-routes and the road Laodikeia-Limyra, movement of the population only in short distances etc.) with ample use of epigraphic evidence. The Christian religion spread mainly in the coastal regions, whereas in the inland the relations to Anatolia and the Anatolian cults prevailed. [AC]

95) A. Frazer, Samothrace. Vol. 10. The Propylon of Ptolemy II, Princeton, 1990: Study of the Propylon at the sanctuary of the Great Gods in Samothrake; F. republishes the building inscriptions on the architraves of the East and West façades of the building dedicated by Ptolemy II to Theoi Megaloi (p. 9495). According to $\mathrm{F}$. the building was constructed by the architect who had built the rotunda dedicated by Arsinoe in the same sanctuary. The building should be dated in the early years of Ptolemy's reign (ca. 285-281, p. 228-231). [AC]

96) D.H. French, Amasian Notes, in $E A, 15$ (1990), p. 135-138 [BE 1991, 581]: Ed. pr. of a dedication of 'steps' $\left(\beta \alpha \sigma \mu \varepsilon i \hat{\delta} \varepsilon \varsigma=\beta \alpha \theta \mu i^{\prime} \delta \varsigma\right)$ in fulfillment of a vow (2, Amaseia, $1 \mathrm{t} / 2$ nd c.); the same word should be restored in $S E G 35,1309$. These rock-cut steps were probably not functional, but played a rôle in the cult of Kybele. A new fragment of the dedication Studia Pontica III.1, 142 shows that the object dedicated by a priest for lifetime from the god's revenues was a statue (3). [AC]

97) S.S. FRERE - M. RoXAN - R.S.O. TOMLIN, The Roman Inscriptions of Britain. Vol. II. Instrumentum Domesticum. Fasc. 1, Gloucester, 1990: Reedition of two inscriptions from Verulamium: $\mathrm{N}^{\circ}$ 2408.2: A Mithraic token formed from a denarius of the year $18 \mathrm{BC}$; the figure (Tarpeia under shields) had been retained to represent the birth of Mithras; the inscription reads: Mi $\theta \rho \alpha \varsigma$

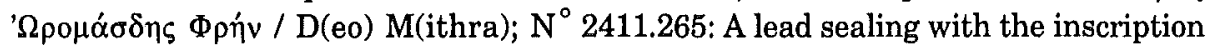
$\delta v v \alpha \dot{\mu} \mu \imath$ (probably a phylactery). [AC]

98) V.F. Gajdukevic, Les villes antiques du Bosphore, Myrmékion, Leningrad, 1987 (in Russian) [ $B E$ 1990, 587]: Mention of graffiti on vases dedicated to Zeus Soter and Aphrodite (Myrmekion). [Non vidimus]. 
99) C. Gallavotti, Revisione di testi epigrafici, in BollClass, 9 (1988), p. 21-31 [SEG 38, 898. 961. 962]: G. reviews the 'Orphic' inscription on a gold leaf from Eleutherna [I. Cret. II,xii 31bis; SEG 34, 1002); he interprets the text as an exhortation to the deceased ("rejoice in Pluto and Persephone") and not as a salute to the gods of the underworld (according to M. GUARDUCCI). G. also comments on two defixiones from Selinous [SEG 26, 1112-1113; for more recent editions cf. now EBGR 1989, $6 \mathrm{n}^{\circ} 59.60$ and $29 \mathrm{n}^{\circ} 29.31$; cf. infra $\mathrm{n}^{\circ} 100$ ]. [ES]

100) M. Garcia Teiseiro, Sobre una defixio antigua de Selinunte (SEG XXVI 1112), in C. Codoñer Mw - P. Fernández Álvarez - J.A. Fernández Delgado (edd.), Stephanion. Homenaje à Maria C. Giner, Salamanca, 1988, p. 105-110: G. restores an archaic defixio addressed against two persons (Selinous, late 6th c.) [now republished by L. DuBoIs (see $E B G R 1989,29 \mathrm{n}^{\circ} 29$ ) and R. ARENA (see $E B G R 1989,6 \mathrm{n}^{\circ} 59$ ); G.'s restoration does not differ essentially from those proposed independently by ARENA and DUBOIS]. G. observs a chiasmus, typical for magical texts, in the use of the curse formula for the two persons: hó $\tau[1]$

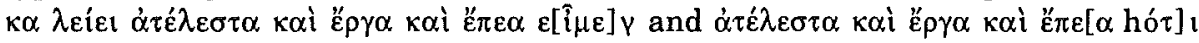
$\kappa \alpha, \lambda \varepsilon i \varepsilon$. [AC]

101*) R. GaRland, The well-ordered corpse: An investigation into the motives behind Greek funerary legislation, in BICS, 36 (1989), p. 1-15 [SEG 39, 1795]: Study of the regulations of funerary rites in ancient Greece, with special reference to the leges sacrae of Delphi (CID 1), Gambreion (LSAM 16), Iulis ( $L S C G$ 97), and Nisyros (IG XII 3, 87). G. demonstrates the variety of motives of these regulations, i.e. the satisfaction of the claims of the dead, the avoiding of pollution, the reduction of funerary expenses, the elimination of public disorder, and the weakening of the political influence of certain clans. [AC]

102) D. GÁsPÁ, Eine griechische Fluchtafel aus Savaria, in Tyche, 5 (1990), p. 13-16 [BE 1991, 144]: Ed. pr. of a defixio on a lead tablet (Savaria,

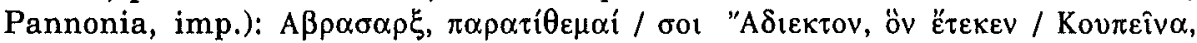

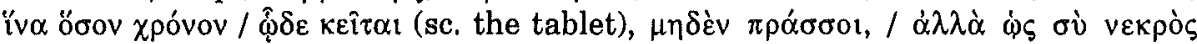

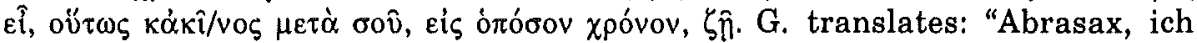
übergebe dir den Adiektos, den Koupeita gebar, damit er, so lange (die Tafel) hier liegt, nichts tun kann, sondern wie du tot bist, so soll auch jener mit dir leben, für

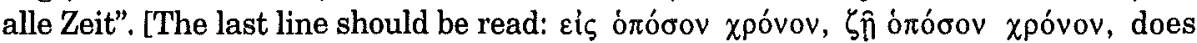
not mean "for ever", but "as long as". Adiektos "should be dead, like you, as long as he lives"; cf. M. SÈVE, in $B E$ 1991, 144.] G. comments on the name Abrasarx (a variant of Abrasax, which can also be undesrtood as $\dot{\alpha} \beta \rho \dot{\alpha} \sigma \alpha \dot{\alpha} \rho \xi)$. [AC]

103) L. Gasperini, Le laminette plumbee iscritte dal ripostiglio dell'agorà di Cirene, in Archeologia Cirenaica, p. 17-33 [BE 1991, 672]: Ed. pr. of two lead tablets found in the agora of Kyrene: 1) A very fragmentary account of transactions (5th/4th c.), perhaps recording a payment to the Delphic Apollon (1. 1); an hieromnemon is mentioned in 1. 4. G. comments on the relations between Kyrene and the Delphic oracle. 2) An account of transactions mentioning eponymous priests and hieromnemones ( $4 \mathrm{th} / 3 \mathrm{rd} \mathrm{c}$.). [Cf. the remarks of C. DOBIASLALOU, in BE 1991, 672]. [AC] 
104) P. Gauthier, Epigraphica, in $R P h, 64$ (1990), p. 61-70: Discussion of the decree of Magnesia on the Maeander concerning the dedication of the statue of Artemis in her new temple and the establishment of the festival Eisiteria (LSAM 33; early 2 nd c. BC). G. restores the passage about the opening of the festival: $\mu \varepsilon \tau \dot{\alpha}$ [ $\tau \hat{\imath} \hat{v} v$

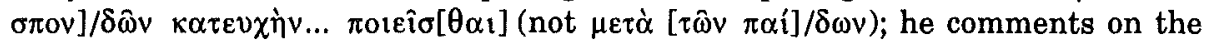
association of libations and prayers ( $\sigma \pi \circ \delta \delta \alpha i$ and $\varepsilon \dot{v} \chi \alpha \hat{i})$ in inscriptions. [AC]

105) D.J. Geagan, Review of G. Petzl, Die Inschriften von Smyrna. Teil II,1, Bonn, 1987 (IK 24,1), in Gnomon, 61 (1989), p. 448-450: G. agrees that Koure Kyprogeneia in I.Smyrna 746 should be identified with Aphrodite; cf. Hesperia, 4 (1935), p. 61-63 $\mathrm{n}^{\circ} 25$ (Koure Paphie). [AC]

106) E. GebhaRd, Ruler's use of theaters in the Greek and Roman world, in Praktika Klas. Arch., 4, p. 65-69: Brief study of the use of theatrical festivals for the glorification of rulers in antiquity and of the rôle of Dionysos as a royal patron; brief discussion of the decree of Gytheion concerning the establishment of the cult of Tiberius and Livia (SEG 11,923, AD 15). [AC]

107) M. Gigante, Una nuova lamella orfica e Eraclito, in $Z P E, 80$ (1990), p. 17-18 [SEG 39, 505]: G. accepts R. MERKELBACH's readings of the new Orphic

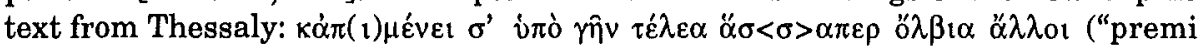
che hanno altri beati attendono anche te sotto terra"); G. associates this verse with

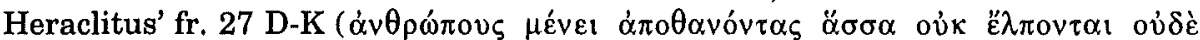

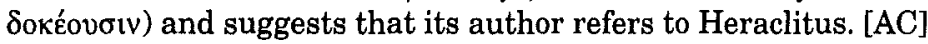

108) A. Grovannini, Le Parthénon, le trésor d'Athéna et le tribut des alliés, in Historia, 39 (1990), p. 129-148: G. challenges the generally accepted view that the sacred money mentioned in the inventories of the Akropolis and in the accounts of the construction of the Parthenon derived from the treasury of the Delian league [cf. infra $\left.n^{\circ} 150\right]$. Contrary to the distinction made between the i $\varepsilon \rho \dot{\alpha}$ and the $\delta \eta \mu o \sigma i \alpha \kappa ı \beta \tau$ '́ $\varsigma$ deposited in the Delian sanctuary, all the transactions recorderd in the accounts of the Akropolis (expenses, loans to the Athenian state and the alliance) refer to sacred money. The treasury of Athena, which financed the building programmes on the Akropolis, had rich sources of revenues (dedications, war booty, the aparche of the allies); on the contrary the limited revenues and high expenses of the alliance make it impossible that the hellenotamiai could have ever collected a surplus of 10,000 talents, i.e. the amount deposited in the temple of Athena. [AC]

109) Z. Go'EvA, Neue thrakische Namen und Epitheta, in Linguistique balkanique, 32 (1989), p. 113-117 [SEG 39, 658-661. 664. 676]: Ed. pr. of four

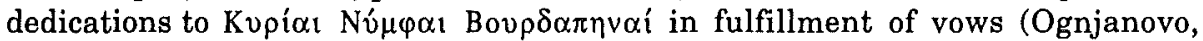

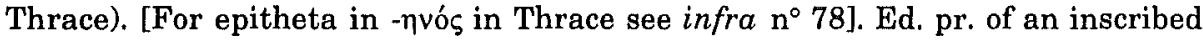

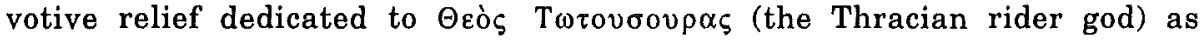
thanksgiving (Odessos). [V. VELKOV, in SEG 39,676 argues that the epithet refers to the Thracian deity Totis]. Discussion of an inscribed votive tablet dedicated to the Thracian rider god (Pravadija, Thrace); the name Kovpels is a personal name, and not the name of the deity (as suggested by A. HARALAMPIEVA - V. IVANOV). [AC] 
110) J. Goodman, in A. Negev, The Architecture of Mampsis. Final Report. I. The Middle and Late Nabatean Periods, Jerusalem, 1988, p. 161 [SEG 38, 1591]: Mention of an inscription on a fresco naming Agathos Daimon (Mampsis, Palaestina). [Non vidimus].

111) N. Grac, Ein neu entdecktes Fresko aus hellenistischer Zeit in Nymphaion bei Kertsch, in H. Franke (ed.), Skythika. Vorträge zur Entstehung des skytho-iranischen Tierstils und zur Denkmälern des Bosporanischen Reichs anläßlich einer Ausstellung der Liningrader Ermitage in München 1984 (Abh. Bayer. Akademie der Wiss., Phil.Hist. Klasse, 98), München, 1987, p. 87-95 [SEG 34, 756; 38, 752; 39, 701; $B E$ 1990, 590): G. presents a fresco found in a room of the sanctuary of Aphrodite in Nymphaion (Black Sea); the sanctuary was built in the late 4th c. and destroyed in the late 3rd c. BC. The fresco (ca. 285-245 BC) contains numerous representations (capricorns, a horse, men, riders, animals, hunting scenes, and more than 30 merchant- and war-ships) and a great number of graffiti: invocations of gods, texts expressing the gratitude of men for divine help, names of participants in the cult (of the type $\dot{\varepsilon} \mu v \eta \dot{\eta} \sigma \theta \eta$ ), verses, sayings, dates of the departure and the coming of ships, receipts of debt payments etc. The deities invoked most often, especially as protectors of seamen, are Aphrodite and Apollon. [But see J. VINOGRADOV, in $B E$ 1990, 590; the inscriptions name persons with theophoric names deriving from Apollon, and not the god himelf]. The inscriptions which record the departure of ships name the months Kalamaion, Thargelion, and Taureon, thus attesting for the first time with certainty the use of the Milesian calendar in the kingdom of Bosporos; the ships departed on the 7th and 20th day of a month, i.e. on days usually devoted to the cult of Apollon. Of great importance is the detailed representation of an Egyptian ship called Isis, probably the ship of ambassadors of Ptolemy II; one of the Dioskouroi is represented under the inscription with the ship's name. [AC]

112*) C. Grottanelli, Do ut des?, in Anathema, p. 45-55: G. supports the view that sacrifice can be explained as "giving in return"; discussion of the votive practice and vocabulary in Greek inscriptions. [AC]

113) M. Guarducci, Riflessioni sulle nuove laminette "orfiche" della Tessaglia, in Epigraphica, 52 (1990), p. 9-19 [SEG 39, 505]: Discussion of the new Orphic leaves from Thessaly [EBGR 1987, 112; 1989, 42. 69. 71; supra $\mathrm{n}^{\circ} 91$.

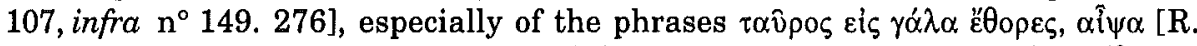

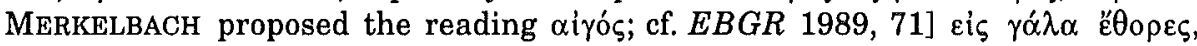

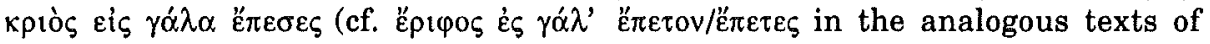
Thourioi). These phrases had been interpreted as expressions of the joyful life of

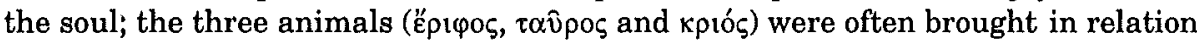
to Dionysos. G. argues that the original formula was inspired by a proverb and only mentioned the épı $\varphi \circ$. The bull and the ram were added later as symbols of the vital forces and in connection with the idea of rebirth. The verb used in the original

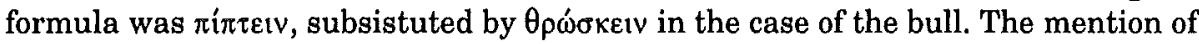
wine in the Thessalian texts was not only connected to the idea of joy but also to Dionysos and to the rites performed by the initiates. [AC] 
114) $\mathrm{H}$. Guiraud, Intailles et camés de l'époque romaine en Gaule (territoire français) (Gallia, Suppl. 48), Paris, 1988 [SEG 38, 1024-1032; $B E$ 1990, 173]: Two inscribed magical gems: p. $191 \mathrm{n}^{\circ} 921$ with a representation of

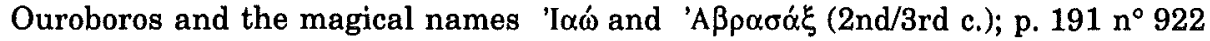
representation of a triple Hekate and a gorgoneion with the names E $\rho \varepsilon \sigma \chi \alpha 1 \gamma \alpha \lambda$ (Ereskhigal) and $\Sigma \varepsilon \mu \varepsilon \sigma i \lambda \alpha v\left(2 n d-4\right.$ th c.); also notice a cameo (p. $\left.203 \mathrm{n}^{\circ} 1010\right)$ with

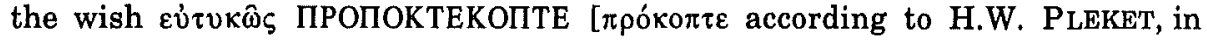

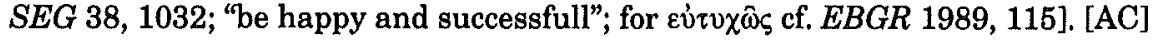

$\left.115^{*}\right)$ W. HAASE (ed.), Aufstieg und Niedergang der römischen Welt. II. Prinzipat, Band 18,1-4. Religion (Heidentum: Die religiösen Verhältnisse in den Provinzen), Berlin-New York, 1987-1990 [SEG 38, $1509 ; B E 1991,86.117 .279 .559)$ : Since all four volumes are devoted to the study of the religion and the different cults in the Roman world under the Principate, a rewiew of all articles is not possible. The various studies contribute to cults of the following regions: Vol, 18,1: Britain, Spain, Gaul, Belgica, Germania; Vol. 18,2: Austria, Pannonia, Dacia, Lower Moesia and Thrace, Attica, Samothrake, Korinth; Vol. 18,3: Ionia, Lykia, Pontos, Phrygia, Pamphylia, Kilikia, Cyprus, Syria, Palaestina, Palmyra, Armenia, Georgia, Iran; Vol. 18,4: Egypt, Kyrenaika, Africa, Numidia, Mauritania, Sicily, Karthago, Sardenia, Italy. [ES]

116) C. Habicht, Samos weiht eine Statue des Populus Romanus, in $M D A I(A), 105$ (1990), p. 259-268 [BE 1991, 124]: Ed. pr. of a basis of a statue of the Populus Romanus dedicated to Hera (Samos, probably ca. $188 \mathrm{BC}$ ). $\mathrm{H}$. discusses the cult of the Demos in Greece (earliest attestation of the cult in Athens in $229 \mathrm{BC}$ ) and the cult of the Roman People (earliest attestation in Delos in ca. $170 \mathrm{BC}$ ). [AC]

117) C. НАВICHт, Ein kaiserzeitliches Familiendenkmal aus Lindos, in $Z P E$, 84 (1990), p. 113-120 [BE 1991, 137]: Restoration and discussion of Lindos 384: $\mathrm{H}$. identifies the person honoured in Lindos $384 \mathrm{~b}$ with T. Flavius Aglochartus; among other offices he had held that of the priest of Athena Lindia and Zeus Polieus and was theoros to the Sebasta of Neapolis (ca. AD 70-80). H. reconstructs the stemma of his distinguished family. [AC]

118) H. HÄusle, Sag mir, o Hund, wo der Hund begraben liegt. Das Grabepigramm für Diogenes von Sinope. Eine komparative literarischepigraphische Studie zu Epigrammen auf theriophore Namensträger, Zürich-New York, 1989 [SEG 39, 39]: Detailed analysis of the grave epigram for the Cynic philosopher Diogenes ( $A P$ VII 64) in view of numerous literary, epigraphic, and archaeological parallels. Notice especially the expression vôv $\delta \grave{\varepsilon}$

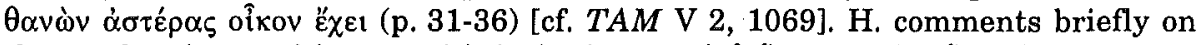

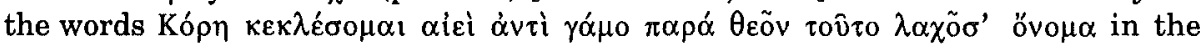
epitaph of Phrasikleia (p. 19-21; CEG 24); the statue of Kore on the grave of the unmarried woman was a visible sign of the epiclese given to Phrasikleia; the maiden was associated after her death with Kore/Persephone. [But see the critical review of P.A. HANSEN, in $C R, 40$ (1990), p. 302-303]. [AC] 
119) H. Halfmann, Hymnoden von Asia in Kyzikos, in Mysische Studien, p. 21-26: Ed. pr. of a list of names (Kyzikos, e. 3rd c. AD). The list (list of prytaneis?) is dated by the eponymous hipparchos (a woman) and the priest of an anonymous deity (probably for lifetime). The persons named in the list include two high-priests for the emperor cult in the city (first attestation in Kyzikos), a priest of Kore Soteira (the main deity of the city), and $3 \dot{v} \mu \nu \omega \delta$ oi 'A $A$ í $\alpha$. This is the first

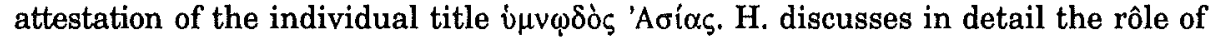
the hymnodoi in the provincial emperor cult. Originally they were recruited from all the cities of the province and sent to the cities where the temples for the emperor cult were established (Pergamon, later Smyrna). However, Claudius decreed that the ephebic associations should provide for the hymnodoi for the various cults; only the hymnodoi serving in the cults of Livia and Roma-Augustus in Pergamon would still be recruted from among the cities of Asia. The new title í $\mu v \omega \delta$ ò $\varsigma$ 'A may imply a province-wide organisation of the hymnodoi. The increase of cityneokories in the early 3rd c. AD and the respective need for new hymnodoi probably meant a heavy financial burden for the cities; $H$. suspects that the system

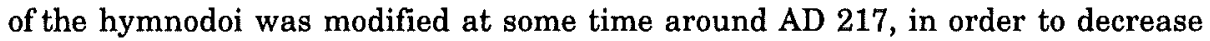
this expenditure. Now the hymnodoi serving in the imperial cult in all cities which had the privilege of neokoreia were recruited from all over the province Asia. The

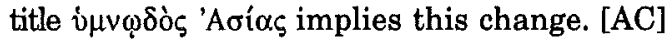

120) O. HANSEN, Epigraphica varia, in $A E, 126$ (1986) [1990], p. 154-159: $\mathrm{H}$. prefers the reading $\theta$ iòs o hotov in the archaic law of Dreros (SGHI 2, 7th c. BC) and interprets this phrase as an invocation ("the god may punish"); the god must be Apollon. [For the same view cf. P.L. POUNDER, in Studies Presented to S. Dow, Durham, 1984, p. 245-250; however, this reading is not certain: see G. GALlavoTTI, in Helikon, 17 (1977), p. 131-132; M. B ILE, Le dialecte crétois ancien, Paris, 1988, p. $29 \mathrm{n}^{\circ} 2$ ]. [AC]

121) O. Hansen, On the date of the Athenian decree regulating the offering of first-fruits at Eleusis, in Eirene, 27 (1990), p. 47-48: The Athenian decree about the aparche offered to Eleusis (LSCG 5) provides for the intercalation of a second Hekatombaion in the next year. This intercalation must have taken place in $421 / 20$ in order to give the time for the restoration of buildings damaged during the Peloponnesian War; a decree of the year 422/1 (IG $\mathrm{I}^{3} 79$ ) ordering the construction of a bridge on the way to Eleusis demonstrates the need for such works. [AC]

122) O. HANSEN, On the helmets dedicated by Hieron to Zeus at Olympia, in Hermes, 118 (1990), p. 498: Two helmets dedicated by Hieron in Olympia [SGHI 29 and $B C H, 84$ (1960), p. 721] bear similar inscriptions: $\Delta i$ Tupóv' d’

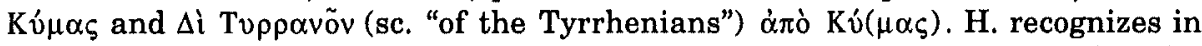
the first inscription an epitheton of Zeus (Zeus Tyrannos) and speculates that the two helmets had been set up beside each other, so that the reader could read the following text: "For Zeus Tyrannos from the Tyrrhenian booty". [AC]

123) O. HANSEN, The date of the archaic dedication of the Lacedaemonians to Olympian Zeus, in Kadmos, 29 (1990), p. 170: The Lacedaemonian dedication to Zeus in Olympia ( $S G H I 47$ ) is brought by Pausanias (V 24,3) in connection with a war of the Spartans against the Messenians. H. proposes an 


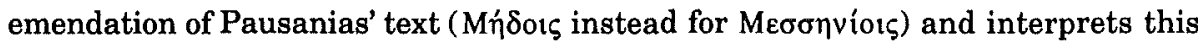
dedication as a thanksgiving to Zeus for the victory over the Persians. Alternatively, it could be a thanksgiving for all the wars in which the Athenians had been involved, dedicated after the Persian Wars. [AC]

124) O. Hansen, Epigraphica bellica: On the dedication of the Athenian portico at Delphi, in C\&M, 40 (1990), p. 133-134 [SEG 39, 473]: The dedicatory inscription on the Athenian portico at Delphi (SGHI 54) refers in general to "the enemies" of the Athenians. According to $\mathrm{H}$. this monument did not commemorate a specific victory, but all the wars of the Athenians previous to 480 $\mathrm{BC}$; this dedication reflects the feeling of security after the last victory in the Persian Wars [cf. supra $\left.\mathrm{n}^{\circ} 123\right]$. [AC]

125) D. HaRVEY, The silent woman of Lydia: Manisa Museum inv. 5414 line 15 , in $L C M, 15$ (1990), p. 28-29: H. proposes the restoration

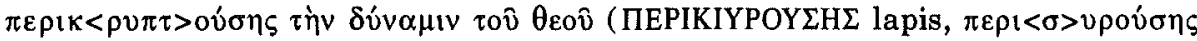
G. PETZL - H. MALAY) in the 'confession inscription' EBGR 1987, 87 [cf. supra $\mathrm{n}^{\circ}$ 53]; the woman's sin lay in her "concealing the god's power". [AC]

126) M.B. Hatzopoulos, Un nouveau document du règne d'Antigone Gonatas, in Poikila, p. 135-148 [SEG 39, 595]: Ed. pr. of two honorary decrees (Kassandreia, final years of Antigonos Gonatas) mentioning an eponymous priest. The eponymous priest is not the one for the royal cult of Lysimachos; he may be a priest of Asklepios [cf. supra $\mathrm{n}^{\circ} 4$ ]. [ES]

127) P. HeIlporn, La provenance de la dédicace I.Th.Sy. 302, in CE, 65 (1990), p. 116-121 [BE 1991, 657]: Discussion of two dedications included in the new corpus of A. BERNARD [EBGR 1989, $8 \mathrm{n}^{\circ} 302$ and 303]. H. shows that the two texts were dedicated by two different associations presided by Herodes; only $\mathrm{n}^{\circ} 303$ (dedication of the Basilistai) was found on the island Es-Sehel; the small temple, where this dedication was found, may be the sanctuary of DionysosPetempamentes. The text $n^{\circ} 302$ was probaby set up either in Elephantine (sanctuary of Chnoum) or in Syene, where Herodes served as phrourarchos. [AC]

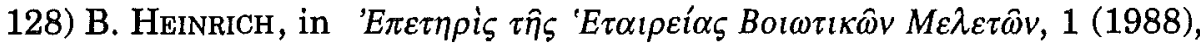
p. 49-50 [SEG 39, 427]: Mention of a dedication to Apollon Paion (Kopais, Boeotia, $3 \mathrm{rd} / 2 \mathrm{nd}$ c.). [Non vidimus].

129*) A. Heinrichs, Between country and city: Cultic dimensions of Dionysos in Athens and Attica, in M. Griffith - D.J. Mastronarde (edd.), Cabinet of the Muses: Essays on Classical and Comparative Literature in Honor of Thomas G. Rosenmeyer, Atlanta, 1990, p. 257-277 [SEG 37, 104-106]: H. warns not to depend exclusively on Euripides' Bacchae for the study of Dionysos and discusses the aspects of his cult in the light of other literary sources (Sophokles, Aristophanes) and inscriptions. The detailed study of the sacrificial calendars of the Attic demes (Teithras, Erchia, Thorikos, Tetrapolis, Eleusis) reveals the distinction between the deme- and the city-religion. The demes did take note of the Dionysiac festivals held in the city, but scheduled their own sacrifices to be offered immediately before or after the city-celebration, in order to give the demesmen the opportunity to attend the city-celebrations. [AC] 
130) R. Hodot, Le dialecte éolien d'Asie, Paris, 1990 [BE 1992, 387]: This study represents a descriptive, synchronical grammar of the inscriptions written in the Aeolic dialect of Asia Minor. It contains a valuable 'repertoire des inscriptions dialectales du domaine éolien d'Asie' (p. 269-317), which comprises all known inscriptions from Lesbos ( Mytilene, Methymna, Eresos), Nesos, Tenedos, Troas, Assos, Myrina, Aigai, Kyme, each one with a detailed entry; among them leges sacrae ( $L S C G$ 124-127) and dedications to various deities. [ES]

131) K. Höghammer, The Koan incorporation of Kalymnos and statues honouring Ptolemy and Arsinoe III, in Akten des XIII. Kongresses für Klassische Archäologie, Berlin 1988, Mainz, 1990, p. 496-497: Discussion of an inscription concerning the honours bestowed upon a King Ptolemy (W.R. PATON - E.L. Hicks, The Inscriptions of Cos, London, 1891, $\mathrm{n}^{\circ} 8, \mathrm{Kos}, 3 \mathrm{rd} / 2 \mathrm{nd}$ c.). $\mathrm{H}$. identifies the honoured person with Ptolemy IV and argues that these honours, including the erection of a cult statue ( $\left.\alpha \gamma_{\alpha} \alpha \lambda \mu \alpha\right)$, were decreed after his death, in recognition of his rôle in the Koan incorporation of Kalymnos. Ptolemy's wife, Arsinoe III, had also been honoured in Kos. [AC]

132) M. Hoff, The early history of the Roman Agora at Athens, in Greek Rennaisance, p. 1-8 [SEG 39, 213]: The Roman Agora at Athens was finished and dedicated to Athena Archegetis probably in $\left.10 \mathrm{BC} \mathrm{(IG} \mathrm{II}^{2} 3175\right)$; the temple of Roma and Augustus on the Akropolis may have been built during the visit of the emperor (19 BC). [AC]

133) A. Hoffmann, Aizanoi 1987, Arbeiten im Stadion, in KST, 10.2 (1988), p. 305-318 [BE 1991, 565]: Mention of honorary inscriptions in the stadion at Aizanioi; they name the high priest of Asia M. Ulpius Eurykles, who probably contributed to the construction of the stadion. [Cf. fig. 6: The texts also mention Appuleius, who had served as priest of Dionysos, high priest of Asia at the temple in Pergamon, and stephanephoros]. [AC]

134*) H. Hoffmann, Rhyta and kantharoi in Greek ritual, in Greek Vases in the J. Paul Getty Museum, Volume 4 (Occasional Papers on Antiquities, 5), Malibu, 1989, p. 130-166 [SEG 39, 53]: Study of rhyta in the shape of animal-heads and their rôle in cult. H. discusses an Attic ram's-head

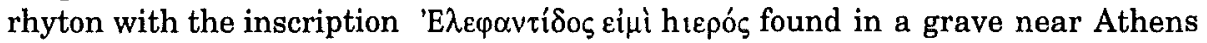
(early 5th c. BC); Elephantis must have been a woman who was accorded heroic honors by her family or a (Dionysiac?) community; the word 'sacred' refers to the ritual function of the rhyton. These pottery vases were a funerary production imitating precious-metal originals; their diffusion in early 5th-c. Athens reflects the rivival of the hero-banquet ritual. From the middle of the 5th c. onwards the herobanquet, in which these vases played an important rôle, merged with the cult of Dionysos and the beliefs of personal salvation and immortality. [AC]

135) A. Hollis, Epops in the Erchian sacred calendar and the Aetia of Callimachus, in E.M. CRAIK (ed.), Owls to Athens: Essays on Classical Subjects Presented to Sir Kenneth Dover, Oxford, 1990, p. 127-130 [BE 1992, 52]: H. speculates that Epops, mentioned in a fragment of Callimachus' Aetia (Supplementum Hellenisticum 238), should be identified with Epopeus, king of Sikyon, and with Epops, whom the Attic deme Erchia offered a sacrifice (LSCG 18 
D 20, E 12). The king of Sikyon may have helped the Erchians in a war against the neighbouring deme Paiania. [AC]

136) B. Holtheide, Neue Inschriften aus Kyme, in Belleten, 53 (1989), p. 545-548 [SEG 1989, 1316; $B E$ 1991, 467]: Ed. pr. of a dedicatory inscription (Kyme, 1st/2nd c.); the oikonomos of the city (responsible for buildings and

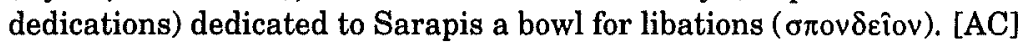

137) G.H.R. Honsley, Greek Documents Illustrating Early Christianity. Volume 5: Linguistic Essays, Marrickville, 1989 [BE 1992, 424]: Among other subjects $\mathrm{H}$. discusses the contribution of Greek documentary sources (mainly inscriptions and papyri) to the lexical study of the New Testament (p. 67.

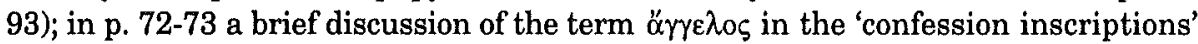
of Lydia and Phrygia. H.'s study of the obtrusion of Semitic features into Greek writers shows that this did not lead to the development of a separate 'Jewish Greek' dialect (p. 5-40). The volume contains numerous addenda to previous volumes of the series (p. 135-150). [AC]

138) J. InAN, Der Demetrios- und Apolloniosbogen in Perge, in MDAI(I), 39 (1989), p. 237-244 [SEG 39, 1388; $B E$ 1992, 521]: Ed. pr. of the inscription on the arch donated by Demetrios, priest of Artemis, and his brother (Perge, ca. AD 8184). The arch is dedicated to Sebaste Eunomia (an allusion to the emperor's justice),

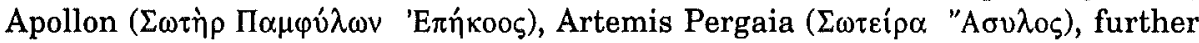
to the city of Perge, the deified emperors Vespasian and Titus, and Emperor Domitian, whose name was erased later. [AC]

139) A. Intzesiloglou, in $A D, 39$ B (1984) [1989], p. 149 [SEG 39, 507]: Mention of a pedimental marble stele dedicated to Dionysos (Pherai, 3rd c. BC). It is the first testimony for Dionysos' cult in the area of the ancient Pherai. [ES]

140) A. Invernizzi, Héraclès à Séleucie du Tigris, in $R A, 1989$, p. 65-113 [SEG 37, 1403; $B E$ 1990, 114]: Detailed study of the bronze statue of Herakles found at Seleukeia on the Tigris; discussion of the cults of Herakles and Apollon in this area [cf. supra $n^{\circ} 24$ ]. I. argues that the temple of Apollon, where the statue had been dedicated, should be identified with the temple of Apollon Komaios, whose cult is attested in the city. In p. 111-113 he discusses the opposite view of P. BERNARD [supra $\mathrm{n}^{\circ}$ 24]. [AC]

141) B. IsAac, in B. MAZAR (ed.), Geva. Archaeological Discoveries at Tell Abu-Shusha, Mishmar Ha 'Emeq, Tel Aviv, 1988 (in Hebrew), p. 224-225 [SEG 38, 1586]: Ed. pr. of two fragmentary inscriptions: 1) An honorific inscription for Abdagos Alexandros honoured as ktistes of the city (Gaba Hippeon, imp.); 2) mention of a high-priest. [Non vidimus].

142) A.F. JACCOTTET, La lierre de la liberté, in $Z P E, 80$ (1990), p. 150-156: Discussion of the lex sacra concerning the procession of Dionysos in Eretria ( $L S C G$ 46) [cf. infra $\mathrm{n}^{\circ}$ 193]. To commemorate Eretria's liberation on the day of this procession (308? BC) the city decreed to celebrate the procession in a more splendid manner. J. comments on the political character of this festival of Dionysos as an anniversary of the liberation of the city, the nature of Dionysos as a liberating god (Lysios), the miraculous way of his actions, and the political aspects of his cult 
(Demosios in Tralleis, Patroios in Megara, Polites in Arkadia, Aisymnetes in Patrai etc., participation of the ephebes in the Athenian Dionysia). J. suggests that the temple of Dionysos near the theatre of Eretria was dedicated to Dionysos Lysios; the second construction phase of the theatre and the construction of this temple may be related to the liberation of Eretria in the late 4th c. [AC]

143) L.H. Jeffery, Poseidon on the Acropolis, in Praktika Klas. Arch., 3, p. 124-126 [SEG 38, 19]: J. argues that the representation of the contest between Poseidon and Athena on the west pediment of the Parthenon alludes to the strife between Athens and Korinth, Sparta, and the Boeotian cities in the first Peloponnesian War; the epigraphic evidence supports the view that Poseidon's cult, associated with that of Erechtheus, was established on the Acropolis, probably by aristocratic families, around $452-447 \mathrm{BC}$, as a reaction against Periclean policy. [On the cult of Poseidon/Erechtheus cf. infra $\mathrm{n}^{\circ}$ 144. 159]. [AC]

144) K. JEPPESEN, Once again: Where was the Erechtheion?, in Praktika Klas. Arch., 4, p. 77-80: After a reexamination of the literary, epigraphic, and archaeological testimonia on the Erechtheion J. argues that it was not a temple, but a compound combining the cult of Poseidon with those of Erechtheus, Hephaistos, and Boutes, i.e. the ancestors of the Eteoboutadai. [On the cult of Poseidon/ Erechtheus cf. supra $\mathrm{n}^{\circ} 143$ and infra $\left.\mathrm{n}^{\circ} 159\right]$. [AC]

145) A. Johnston, Aeginitans abroad, in Horos, 7 (1989), p. 131-135 [SEG 39, 950; $B E$ 1992, 227]: The dedication to Apollon, found in Agia Pelagia (Apollonia?, Crete, ca. 500 BC; $S E G 34,913$ ), is written in the Aeginitan alphabet. The inscribed cauldron was either dedicated by a Kydonian (or an Aeginitan) in a sanctuary in Apollonia or was captured spoil from an Aeginitan sanctuary. [AC]

146) A. Johnston, Anotherathema, in Anathema, p. 311-316: J. studies a group of four graffiti on vases (arch.); they record the dedication of two objects

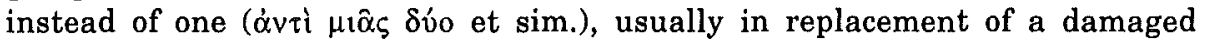
dedication; he also discusses in general the dedication of damaged or repaired objects in sanctuaries. [AC]

147) D.R. Jordan, New defixiones from Carthage, in J.H. Humphrey (ed.), The Circus and a Byzantine Cemetery at Cathage, Ann Arbor, 1988 , p. 117-134 [BE 1991, 143]: Ed. pr. of three defixiones (2 Greek, 1 GreekLatin) from the Circus of Carthago (1. 3rd c. AD) and survey of all the curse tablets hitherto found in this city. 1) A Greek defixio against a charioteer; the text is similar to two other defixiones from Carthago (252-253 Audollent), probably written by the same scribe. The long text (more than 33 lines) contains many known voces magicae, a palindrome (1. 1), and numerous magic names $\left(\operatorname{I} \alpha \beta \varepsilon \zeta_{\varepsilon} \beta v \theta\right.$, Ev $\lambda \alpha \mu \omega$, $\Theta \varepsilon \theta \omega v \iota, \Pi \alpha \kappa \alpha \rho \theta \alpha \rho \alpha$ etc.). Particularly interesting is the invocation of Iao-Seth, who is called "the grasper of the k $\alpha$ jò $\varsigma$ of Sodoma and Gomorah"; this expression reveals Jewish influence. 2) A fragmentary Greek defixio (32 lines); J. recognizes a few known Greek voces magicae. 3) A Greek-Latin defixio against charioteers and their horses. A crude drawing shows a bound man with crossed legs and arms; three texts are written around the figure: a) Signa magica, the name $\Sigma \varepsilon \mu \varepsilon \sigma \varepsilon 1 \lambda \alpha \mu$ (in Greek), and a Latin curse against a charioteer; b) signa magica, a sequence of 
vowels, and the name $A \beta \rho \alpha \sigma \alpha \xi$ (in Greek); c) a Latin text referring to the binding of the tamaci (a new word, "intesines"?) and feet of a charioteer. [AC]

148) D.R. JoRDAN, New archaeological evidence for the practice of magic in classical Athens, in Praktika Klas. Arch., 4, p. 273-277 [SEG 38, 31; $B E$ 1991, 37. 142]: J. presents a group of defixiones found in the graves of two boys in Kerameikos (ca. $400 \mathrm{BC}$ ). The lead tablets were folded into the shape of boxes each with a lead figurine inside; the figurines represent men with their hands bound behind their backs and with exaggerated genitals. The curse texts (mainly names of men) imply that they were used against legal opponents. J. adduces other parallels for the practice of sympathetic magic in Athens and the use of similar lead "voodoo dolls" in ancient Greece. [AC]

149) D.R. Jordan, $A$ note on a gold tablet from Thessaly, in Horos, 7 (1989), p. 129-130 [SEG 39, 505; $B E 1992,45]$ ]: J. proposes the following reading

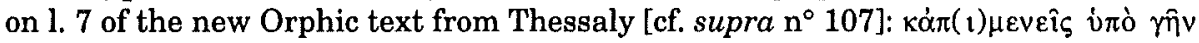

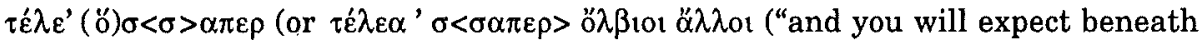
the earth what $\tau \dot{\varepsilon} \lambda \varepsilon \alpha$ the other blessed ones expect"; cf. the 11. 15-16 of the text from Hipponion). [AC]

150) L. Kallet-MaRX, Did tribute fund the Parthenon?, in ClAnt, 8 (1989), p. 252-266 [SEG 39, 25]: K.-M. argues against the traditional view that the tribute of the Athenian allies was used for the construction of the Parthenon. After an examination of the combined evidence of Plutarch (Per. 12.2) and the Parthenon building accounts she reaches the conclusion that the chief source of financing this project was rather the treasury of Athena, which did not contain the tribute surplus, but received revenues from a wide range of sources (gifts, fines, confiscations, leasing of sacred land etc.) [cf. the similar views of G. GIOvANNINI, supra $\mathbf{n}^{\circ} 108$ ]. [ES]

151) P. Kalligas, 'A p. 92-97 [SEG 38, 20; $B E$ 1990, 157]: Discussion of an Athenian workshop of metallurgy (early 5th c.). A bronze mirror dedicated by Hippyla to Artemis of Brauron (Ergon 1961, p. 33) and a lekanis dedicated by Hippylos to Athena on the Acropolis (ed. pr.) are products of the same workshop; the names of the dedicants imply that they belonged to the same family. [AC]

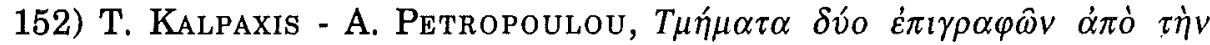

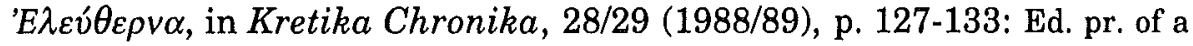
fragmentary inscription from Eleutherna (Crete), probably a lex sacra (2nd c. BC); the text mentions sacrifices offered to various deities (Zeus Machaneus?, Artemis Agrotera?). [AC]

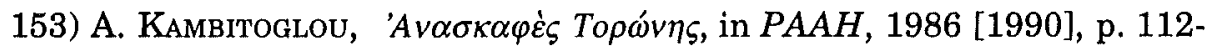
131: Mention of a graffito on a storage amphora found at Lekythos (Torone); the name of Athena can be restored on it; her sanctuary is mentioned by Thucydides (IV 156,2) [cf. supra $\mathrm{n}^{\circ}$ 245]. [AC]

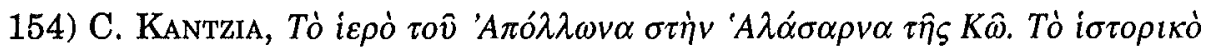
$\mu \imath \hat{\alpha} \varsigma \kappa \alpha \tau \alpha \sigma \tau \rho \circ \varphi \hat{\eta} \varsigma$, in $A D, 39$ A (1984) [1990], p. 140-162: Report of the archaeological investigation of a Hellenistic structure (3rd c.) in Halasarna (Kos) 
which can be identified with the temple of Apollon. A still unpublished inscription (late 3rd c. BC) concerning a subscription for the construction of Apollon's temple refers to this building. The sanctuary had a long existence, from the archaic to imperial times. $\mathrm{K}$. mentions numerous epigraphic finds: 3 graffiti on craters dedicated to Apollon (5th c.); a dedication to Hekate Stratia by the priest of Apollon and the six hieropoioi (ca. $200 \mathrm{BC}$ ); a dedication to Apollon; a dedication to Claudius identified with Poseidon Asphaleios; a long honorific decree (2nd c.) for 9 men who should be crowned by the priests during the festival Pythaia, on the 17th and 18th day of the month Dalios; the new texts show that Apollon's epitheton was Pythaios or Pythaeus, and not Dalios as suggested by R. HERzoG. Another honorific decree for an $\dot{\alpha} \rho \chi \varepsilon \dot{\sigma} \sigma \alpha \varsigma \pi \alpha \rho$ ' 'H $\rho \alpha \kappa \lambda \hat{n}$ mentions the temple of Apollon (m. 3rd c. BC). The new finds show that Apollon was worshipped in this sanctuary along with Hekate Stratia and Herakles. K. mentions two further inscriptions found in Halasarna, an altar dedicated to Zeus Kataibates, whose cult is attested for the first time on Kos, and a dedication to Hermes, whose cult is attested for the first time in Halasarna (3rd c. BC). [AC]

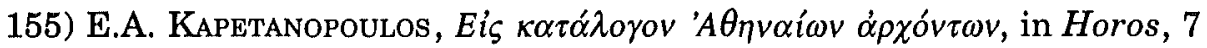
(1989), p. 21-31 [BE 1992, 243]: K. discusses the development of the title of the

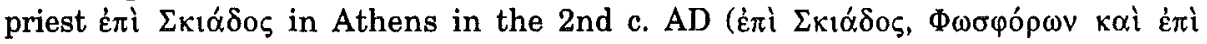

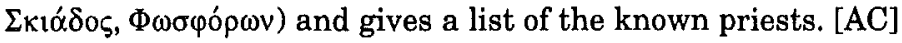

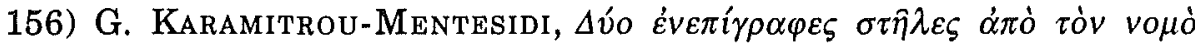

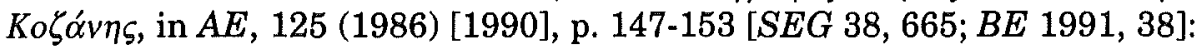
Ed. pr. of a dedication to Apollon Hekatombios (Kastro Kozanis, Eordaia, 1st c. BC). It is the first attestation of this epitheton in Macedonia. The relief on the stele represents Apollon Kitharodos. [AC]

157) I. Karamut, Pisidia Antiocheia'si yakininda buluman Men kutsal alani, in Türk. Ark. Dergisi, 28 (1989), p. 177-187 [BE 1991, 588]: $K$. reports the find of numerous dedications to Men Askainos, found at his sanctuary (Antiocheia in Pisidia). The dedications are of the type Mnví + personal

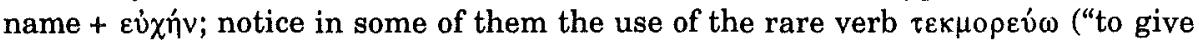
the sign of loyalty") attested only in inscriptions of this region. [ES]

158) R. Kassel, Die Phalaeceen des neuen hellenistischen Weihepigramms aus Pergamon, in ZPE, 84 (1990), p. 299-300: Metrical analysis of the epigram dedicated to Dionysos and Attalos I (Pergamon; EBGR 1989, 77; BE $1990,57.147$; cf. infra $\mathrm{n}^{\circ} 187$ ); K. argues that the poet of the epigram was probably influenced by Callimachos (fr. 196,1 Pfeiffer). [On this epigram see also A. KERKHECKER, Zum neuen hellenistischen Weihepigramm aus Pergamon, in ZPE, 86 (1991), p. 27-34]. [AC]

159*) E. Kearns, The Heroes of Attica (BICS, Suppl. 57), London, 1989 [SEG 39, 144. 319]: Thorough study of the cult of heroes in Attica with ample use of inscriptions (including the sacrificial calendars of Attica). The book includes a study of healing and seafaring heroes, kourotrophic heroines, the eponymous heroes of the genê, orgeones, deme, and tribes, the cult associations of heroes, and the rôle of heroes as protectors of the city. A catalogue of Attic heroes is given in Appendix I. In Appendix II K. argues that the priest of Erechtheus, selected from 
the tribe Kekropis, served for both the tribal and the public cult of the hero (Agora XV 98); she discusses briefly the history of the cult of Poseidon Erechtheus in Athens (cf. $I G \mathrm{II}^{2} 1146=L S C G$ 31). [On this cult cf. supra $\mathrm{n}^{\circ} 143.144$ ] [AC]

160) R.A. KeARSLey, Asiarchs, Archiereis and Archiereiai of Asia: New evidence from Amorium in Phrygia, in EA, 16 (1990), p. 69-80 [BE 1992, 482]: Prosopographical remarks on the recently published honorific inscription for the high-priestess of Asia Aelia Ammia ( $E B G R$ 1988, 66, Amorion, m. 2nd c. AD). Aelia Ammia is identified as the person honoured in I.Ephesos III 689; she had also held the office of a co-priestess of the Ionian Koinon. K. reconstructs the stemma of her husband's family (M. Iulius Damianus of Mylasa), which was one of the most eminent families in Asia. Their son, M. Iulius Aquila, bears the title Asiarch in the inscription of Amorion and that of the high-priest of Asia in an inscription of Ephesos (I.Ephesos III 686); it is not clear whether these titles are synonymous (as argued by J. DEININGER) or designate two offices held successively by the same person [as suggested by K.; cf. $E B G R$ 1988, 81; but see the objections of J. MOLTHAGEN, Die ersten Konflikte der Christen in der griechisch-römischen Welt, in Historia, 40 (1991), p. 66-67 note 141; cf. $B E$ 1992, 402], or if the title Asiarch was an honorary title used for life by ex-archiereis (according to R. MERKELBACH). The

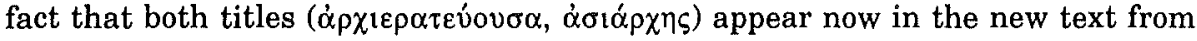
Amorion strengthens the view that these two offices were separate; Aelia Ammia served as high-priestess in the same year as her son was Asiarches. [AC]

161) D. Knoepfler, Dédicaces érétriennes à Ilithyie, in AK, 33 (1990), p. 115-128: Ed. pr. of a fragmentary dedication to [Artemis] Eileithyia (Acropolis of Eretria, ca. $300 \mathrm{BC}$ ). K. collects and discusses the other epigraphic testimonies for Eleithyia's cult in Eretria. He proposes a new reconstruction of the two fragments of a dedicatory basis found in the NW edge of the building known as the 'lower gymnasium' (IG XII Suppl. 572 and 560, joined by V. PetraKos). K. restores the name of Eileithyia (instead of Hermes) in IG XII Suppl. 559 found at the same spot. This building was a gymnasium, in which Eileithyia was worshipped. The existence of another sanctuary of the kourotrophic deities can be inferred from a boundary stone (IG XII 9, 269). It is not clear whether the dedication to Artemis Kolenis (IG XII 9, 1262), was found in Eretria or in Myrrhinous in Attica. [AC]

162) D. KNOEPFLER, The calendar of Olynthus and the origin of the Chalcidians in Thrace, in J.-P. Desconudres (ed.), Greek Colonists and Native Populations. Proceedings of the 1st Australian Congress of Classical Archaeology Held in Honour of em. Prof. A.D. Trendall, Sydney 9-14 July 1985, Oxford, 1990, p. 99-115: Study of the calendar of Olynthos. K. eliminates the alleged evidence for non-Ionian names of months in Olynthos and supports the Euboean origin of the calendar of the Chalcidians in

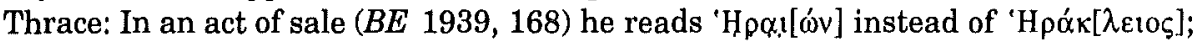
since this relatively rare month is attested in the calendars of Eretria and Chalkis and since Hera was worshipped in Chalkis, the month Heraion probably derived from this city. Another act of sale with the month-name Hyperberetaios was probably not found in Olynthos, but either in Kassandreia, which adopted the Macedonian calendar in the 3rd c. BC, or Antigoneia. The positively attested month-names (Apatourion, Lenaion, Targelion, Kalamaion, Hippion, Pantheon, 
Artemision?) reveal a remarkable correspondence to the Euboean calendar (notice e.g. the form Targelion, instead of Thargelion). The four missing names of Olynthos' calendar were probably Anthesterion, Bouphonion, Olympion, and Demetrion. [Cf. $E B G R$ 1989, 57]. Arguing that the calendar is the safest clue for the determination of any Greek population's origin $K$. challenges M. ZAHRNT's view that the Chalcidians in Thrace were a native Greek tribe of Ionian stock, established there by the end of the Mycenaean times. [AC]

163) G. Koch, Einige Weihreliefs aus Phrygien, in Festschrift Inan, p. 539-545: Discussion of a group of reliefs dedicated to Zeus Ampelites and Zeus Thallos (NW Phrygia, 3rd c. AD). [On the dedicatory inscriptions see EBGR 1987, $53=B E$ 1990, 748; SEG 37, 1169-1170; EBGR 1988, $84=B E$ 1990, 746; SEG 38, 1313]. [AC]

164) G. Koch, Sarkophage der römischen Kaiserzeit im Nationalmuseum in Damaskus, in MDAI(D), 4 (1989) [1990], p. 163-179: Ed. pr. of an epitaph of a woman from Kasos with a funerary imprecation against those, who would sell or give away or pledge the sarcophagus (8, Laodikeia, 3rd. c. AD). [ES]

165) F. Kolb, Sitzstufeninschriften aus dem Stadion von Saittai (Lydien), in EA, 15 (1990), p. 107-119: Publication of the inscriptions on the steps of the stadion at Saitatai (Lydien, imp.). The inscriptions mention the names of the phylai; several of them were named after important deities worshipped in the city (Apollonias, Asklepias, Dionysias, Herakleis). [AC]

166) F. Kolb - M. Zimmermann, Neue Inschriften aus Kyaneai und Umgebung, in $E A, 16$ (1990), p. 115-138 [BE 1991, 85; 1992, 473]: Ed. pr. of inscriptions from Kyeneai (Lykia): An inscription referring to the construction of a temple dedicated to Eleuthera, the $\dot{\alpha} \rho \chi \eta \gamma \varepsilon$ tı of the city, and to the Demos (1, 1st c. $\mathrm{BC} / \mathrm{AD}) ; \mathrm{Z}$. offers a detailed commentary on the cult of Eleuthera in Lykia; this cult was probably separate from that of Artemis; a dedication to Zeus (2, Hell.); a grave altar dedicated to the gods $(3, \mathrm{imp}$.$) . [AC]$

167) J. Kolendo, Les dieux protégeant la tombe contre la violation dans une inscription de Novae, in Eos, 78 (1990), p. 377-379: Ed. pr. of a Latin funerary imprecation (Novae). [Note the expression [h]abebit deos i[ratos] which

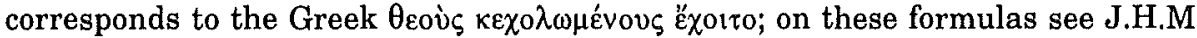
STRUBBe, Vervloekingen tegen grafschenners, in Lampas, 16 (1983), p. 248-274 and "Cursed be he that moves my bones", in C.A. FARAONE - D. OBINK (edd.), Magika Hiera, New York-Oxford, 1991, p. 33-59]. [AC]

168) J. Kolendo, Miejsca kultu religijnego $w$ Novae (The place of the religious cult in Novae), in Balcanica Posnaniensia, 5 (1990), p. 227-238 (in Polish, with English summary): Presentation of the Latin inscriptions found at the aedes signorum of the headquarters of the legio prima Italica in Novae; three inscriptions attest the cult of Asklepios and Hygieia at the valetudinarium [cf. $E B G R$ 1989, 58]. The cults of Juppiter Dolichenus, Isis, Quadriviae and Magna Mater are attested indirectly. [AC] 
169) E. Konsolaki, in $A D, 35$ B (1980) [1988], p. 95-96 [SEG 38, 324]: Mention of an inscription found at the sanctuary of Poseidon in Kalaureia recording a dedication made to Poseidon by the same family which made the dedications referred to in IG IV 840.841. 843 (?). 844, and 846. [AC]

170) C. Koukouli-Chrysanthaki, in $A D, 40$ B (1985) [1990], p. 263-266 [BE 1991, 415]: Report on the excavation at the sanctuary of Heros Auloneites (Kipia, Macedonia) [cf. $E B G R$ 1989, 62; infra $\mathrm{n}^{\circ} 237$ ]. The sanctuary was in use from the 2nd c. BC to the 4th c. $A D$; the name of the deity worshipped there before the imperial times is not known, but it is probable that it was a hero analogous to Heros Auloneites, whose cult flourished in the 2 nd c. $\mathrm{AD}$. The hero is usually represented as a riding hunter accompanied by a dog approaching an altar; a snake twists around a tree near the altar. Numerous new dedicatory inscriptions name Heros Auloneites. [AC]

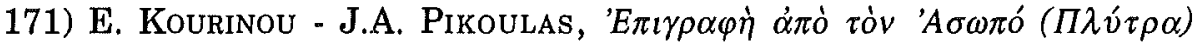
$\Lambda \alpha \kappa \omega \nu i \alpha \zeta$, in Horos, 7 (1989), p. 24-29 [BE 1992, 257]: Ed. pr. of an inscription commemorating the dedication of a bath to the emperors (Theoi Sebastoi, Asopos in Lakonia, 1st/2nd c.). [AC]

172) W.K. Kovacsovics, Kerameikos. Band XIV. Die Eckterasse an der Gräberstraße des Kerameikos, Berlin-New York, 1990: Ed. pr. of the boundary stone of a grave (p. 68 I 510, Kerameikos, late 5th c.). [AC]

173) R.S. KRAEMER, On the meaning of the term "Jew" in Greco-Roman inscriptions, in HTR, 82 (1989), p. 35-53 [SEG 39, 1839]: K. demonstrates the

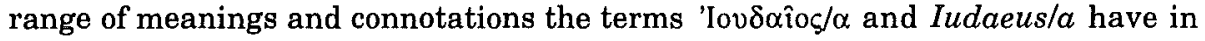
Graeco-Roman inscriptions (geographical origin, pagan adherence to Judaism etc.). The names Ioudaios/a were also used as proper names by non-Jews who affiliated with Judaism. [AC]

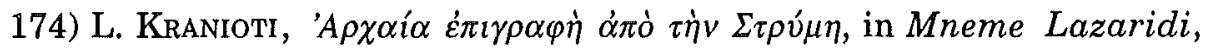
p. 629-636 [BE 1991, 210. 221]: Ed. pr. of the boundary stone of the shrine of Podaleirios and Machaon (Stryme, e. 4th c. BC). K. offers three alternative interpretations for the last lines ( $\pi \varepsilon p 1 \varepsilon \sigma \tau \dot{\omega} \varsigma$ 'A $A \eta v \alpha$ ins): a) "around the sanctuary of Athena"; b) "Athenaes after his cure"; c) "of Athena Periesto". [O. MASsoN, in BE 1991,210 and 221 rightly points out that Periesto ("Guérison") is a divine name: the sanctuary was dedicated to the cult of Podaleirios, Machaon, Periesto, and Athena]. [AC]

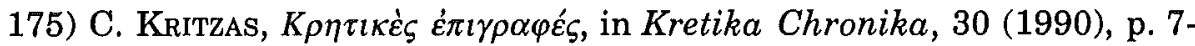
17: Ed. pr. of a dedication to Theos Hypsistos (1, Knosos, 1st/2nd c.); this cult was already attested in various other parts of Crete. [AC]

176) S.M. KRyKIn, A votive basrelief of a Thracian horseman from the Poltava Museum, in VDI, 1990.1, p. 74-79: Reedition of a relief dedicated by a

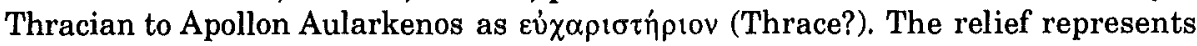
a Thracian horseman. [AC] 
177) V. Lambrinoudakis, Neues zur Ikonographie der Dirke, in Festschrift Himmelmann, p. 341-350: Ed. pr. of a statue of an armoured man dedicated to a $\Theta \varepsilon \dot{\zeta} \zeta K \alpha \hat{\imath} \sigma \alpha \rho$ (probably $[\Sigma \varepsilon \beta \alpha \sigma] \tau \hat{\omega} \imath$ $\Theta \varepsilon \hat{\omega} \iota \mathrm{K} \alpha \hat{i} \sigma \alpha \rho \jmath$, i.e. Augustus) [cf. IGR III 932. 934]. L. argues that the statue originally represented Marc Antony, and was later changed into a statue of Augustus (Naxos, late 1st c. BC). [AC]

178) V. LAMBRINOUDAKIS, Un réfugié argien à Épidaure au Ve siècle av. J.-C., in CRAI, 1990, p. 174-183: Ed. pr. of a bronze tablet found at the sanctuary of Apollon Maleatas (Epidauros, 5th c. BC). The text, composed in dochmiac verses, was dedicated by an Argive suppliant (h sanctuary of Apollon Pythios (sc. Maleatas). The dedicant found refuge in the sanctuary together with his dependant peasants (Foเkı $\tilde{\alpha} \alpha 1)$. [Notice the remarks of J. MARCADÉ, ibid ., p. 183-185 on suppliants in sanctuaries]. [AC]

179) S.B. Lancov - V.I. Pavlenkov, Review of B.I. SolomoniK, Graffiti $s$ khory Khersonesa, Kiev, 1984, in VDI, 1988.3, p. 178-188 [SEG 39, 749; BE

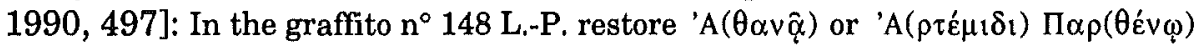
(Chersonesos). [AC]

180*) E.N. Lane, Corpus Cultus Iovis Sabazii. III. Conclusions (EPRO, 100), Leiden, 1989 [SEG 39, 1856]: In the last volume of the corpus of the archaeological and epigraphic monuments concerning the cult of Sabazios L. discusses the history of the cult and studies the cult practices. [AC]

181) E.N. LANE, A bronze base from Syria, in Muse, 23/24 (1989/90), p. 7481 [SEG 39, 1611]: Publication of a bronze base with a dedicatory inscription (Syria); the base, decorated with incised representation of the sun and the moon, is surmounted by an omphalos, which supported a statuette. The statuette (of Apollon?) may have been dedicated to Apollon in the sanctuary of the Syrian Goddess at Hierapolis. [AC]

182) E. LANE, Vorschlag zum Verständnis einer Sühneinschrift aus Bergama, in $E A, 15$ (1990), p. 120 [BE 1991, 504]: L. translates the 'confession inscription' EBGR 1988, $105 \mathrm{n}^{\circ} 4$ as follows: "After the gods of the Perkenoi <and> Zeus Oreites had given the warning not to feed the cattle in the grove, <and> they did not obey etc." [H. MALAY: "since the gods of the Perkenoi had given the forewarning to the people who were constantly disobedient, not to feed cattle in the grove (of) Zeus Oreites"; but see the objections of C. BRIXHE - A. PANAYOTOU, in BE 1991, 504]. [AC]

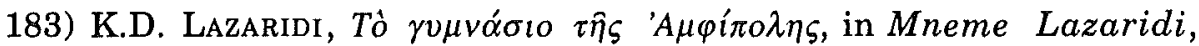
p. 241-273 [ $B E 1990,486]$ : Survey of the inscriptions found at the gymnasium of Amphipolis [see already EBGR 1988, 94-95]. [AC]

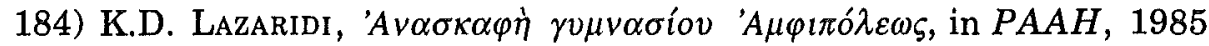
[1990], p. 69-75: Mention of several new inscriptions found at the Hell. gymnasion of Amphipolis: a dedication to Herakles by a gymnasiarch, an inscribed perirrhanterion (p. 74), and a dedication to Hermes (p. 71) [cf. $E B G R$ 1988, 95]. $[\mathrm{AC}]$ 
185) M.L. Lazzarini, Necrocorinthia a Pompei: una idria bronzea per le gare di Argo. L'iscrizione, in Prospettiva, 53-56 (1988/1989), p. 42-48 [SEG 39, 1061]: Ed. pr. of an inscription on an Argive prize hydria found in

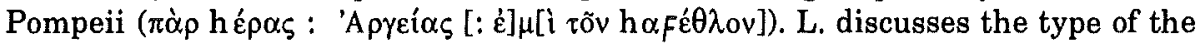
hydria and the Argive festival (Heraia), on which it was given as a prize (m. 5th c. $\mathrm{BC}$ ); the inscription is comparable to those incised on five other Argive prize hydrias [cf. $E B G R$ 1989, 64]. [ES]

186*) M.L. LAZzARINI, Iscrizioni votive greche, in Anathema, p. 845-859: An excellent presentation of the main formulas in Greek private dedications and their development from the archaic to imperial times; discussion of the religious ideas and the development of the relation between man and deity revealed by this vocabulary. $\mathrm{L}$. analyses the typical structure of dedicatory formulas (name of the dedicant, verb $\alpha v \alpha \tau \imath \theta \varepsilon v \alpha$ name of the deity), the words which designate the

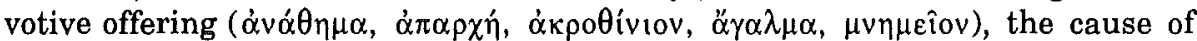

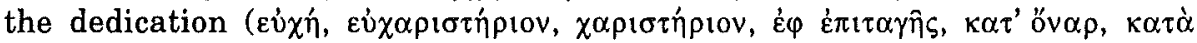

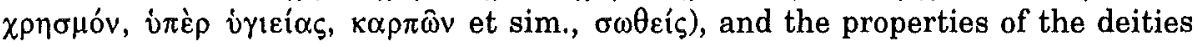

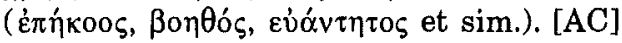

187) W.D. Leber, Neue Phalaikeen aus Pergamon, in $Z P E, 82$ (1990), p. 297-298 [SEG 39, 1334; $B E$ 1991, 46]: Minor restorations in the dedicatory epigram to Dionysos and Attalos I (Pergamon); [cf. supra $\mathrm{n}^{\circ}$ 158]. [AC]

188) A. LeBESSI, in $A D, 41 \mathrm{~B}$ (1986) [1990], p. 238: Mention of an inscribed relief dedicated to the Eleusinian hero Keramos (4th c. BC). [AC]

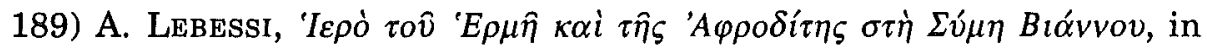
$P A A H, 1985$ [1990], p. 263-285: Mention of a dedicatory inscription (with the verb $\varepsilon(\eta \eta \kappa \varepsilon$ ) on the basis of the bronze statuette of a nude man (sanctuary of Hermes, Simi Biannou, Crete, ca. 475-450). [AC]

190) C. LE Roy, Rapport sur les fouilles et restaurations à Xanthos et au Létoon en 1986, in KST, 9.2 (1987), p. 215-224 [BE 1990, 734]: Mention of inscribed postaments of statues of the governor L. Domitius Apollinaris and members of his family, who had contributed to the reconstruction of the Letoon (Xanthos, ca. $\mathrm{AD}$ 93-96). [AC]

191) C. Le Roy, Travaux et restaurations au Létoon et à Xanthos en 1988, in $K S T, 11.2$ (1989), p. 177-184: Mention of an inscription which attests the cult

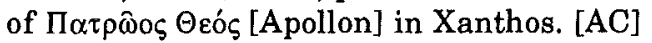

192*) F. LÉToublon, Le serment fondateur, in Métis, 4 (1989), p. 101-115 [SEG 39, 1716]: Discussion of the oath of the Therean colonists sent to Kyrene (MEIGGS-LEwIS, GHI 5) in view of the theory of "actes de langage"; L. compares the imprecation described in this inscription ceremony with the narrative of Livius on the imprecations performed at the founding of Rome. [AC]

193) N. Lewis, The "Ivy of Liberation" Inscription, in GRBS, 31 (1990), p. 197-202: The lex sacra concerning the procession for Dionysos in Eretria (LSCG Suppl. 46) [cf. supra $\mathrm{n}^{\circ} 142$ ] is known only from a copy made by Cyriacus of Ancona. L. proposes a new division of the text into lines and discusses two 


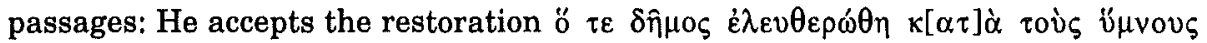
(proposed by A. BOECKH); the word ü $\mu$ vo $\varsigma$ is used here in the meaning "oracle" (as suggested by T. REINACH). According to the decree all the inhabitants of Eretria should wear ivy-crowns on the procession for Dionysos; according to L.'s understanding of the fragmentary lines, the citizens would obtain their crowns at public expense, whereas all the others would rent them. The renting out of wreaths means that they were reusable; the wreaths were probably made of ivy and then covered with a paint or other substance. [AC]

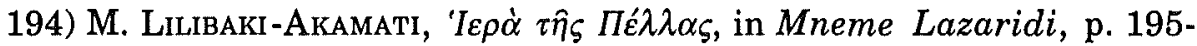
203 [ $B E$ 1990, 462]: Presentation of two sanctuaries recently excavated in Pella, the sanctuary of Kybele and Aphrodite, where inscriptions dedicated to Meter Theon and Aphrodite were found (Hell.), and the sanctuary of Demeter Thesmophoros (4th-2nd c.). [AC]

195) T. Linders, The melting down of discarded metal offerings in Greek sanctuaries, in Anathema, p. 281-285: The temple inventories of Athens and Delos refer to the practice of melting down damaged metal offerings (vessels, tablets, coins); the metal was either used to cast new votive offerings (Asklepieion of Athens, sanctuary of Heros Iatros in Athens, Amphiareion of Oropos) or was cast into ingots (Delos), which were deposited in the sanctuary and were treated as offerings. This practice shows that it was not allowed to remove dedications from sanctuaries [cf. T. LINDERS, Gods, gifts, society, in T. LINDERS G. NoRDQuist (edd.), Gifts to the Gods. Proceedings of the Uppsala Symposium 1985 (Boreas, 15), Uppsala, 1987, p. 115-122]. [AC]

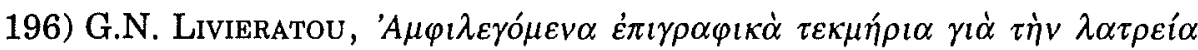

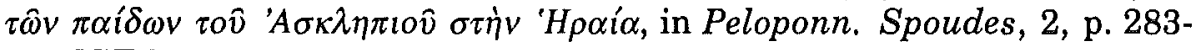
288 [SEG 38, 339]: A dedication to the sons of Asklepios refers to their cult in Heraia (not in Thelpousa); the dedicant can be identified with Timarchis, daughter of Leon, who made another dedication in the sanctuary of Asklepios at Messene (late 3rd c. BC). [AC]

197) T. Lochman, in Revue du Louvre, 6 (1990), p. 455-461 [BE 1991, 21]: Funerary stele dedicated to Hekate (Phrygia, 3rd c. AD). [Non vidimus].

198*) E. Loucas, Le nom de la thea Despoina, in Peloponn. Spoudes, 2, p. 401-419: L. discusses the cult of Despoina in Lykosoura (Arkadia); the archaeological and epigraphic evidence support the identification of Despoina with Artemis. Discussion of $I G$ V 2, 522 (dedication to Despoina Artemis) and 525 (dedication to Despoinai Epekooi, i.e. Demeter and Despoina). [AC]

199) L.D. Loukopoulou, Contribution à l'histoire de la Thrace Propontique durant la période archaique, Athens, 1989 [SEG 39, 641]: Thorough study of the early history of Thrace on the Propontis with a discussion of the local cults (at Ainos, Maroneia, Perinthos, Selymbria, and Byzantion): the cult of Hera in the Samian colonies (Perinthos, Bisanthe, Heraion, p. 96-103); the cults of the Megarian colonies Byzantion and Selymbria (Apollon Pythios, Demeter Malophoros, Artemis Orthosia, Artemis Phosphoros, p. 103-109); reconstruction of the calendars of Perinthos (p. 110-120), Byzantion-Selymbria (p. 120-122), and Samos (p. 407-416: Posideon, Lenaion, Anthesterion, Artemision, Taureon, 
Thargelion, Kalamaion, Panemos, Metageitnion, Boedromion, Kyanopsion, Apatourion. H. BIScHOFF, s.v. Kalender, in RE, X.2 (1919), p. 1585 had the sequence Panemos-Kronion-Pelysion, instead of Thargelion-Kalamaion-Panemos). [AC]

200) J. Magness, Some observations on the Roman temple at Kedesh, in IEJ, 40 (1990), p. 173-181: Some [rather superficial] similarities between the architectonic plan of the Roman temple of Baalshamin (the Greek inscriptions call

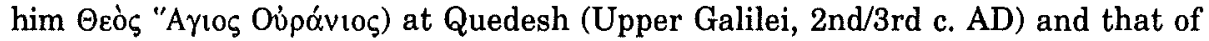
Apollon's temple at Didyma lead M. to the assumption that the temple at Quedesh served as an oracle. [AC]

201) H. Malay, Some Mysians "from Emoddi", in EA, 16 (1990), p. 65-68 [BE 1992, 426]: Ed. pr. of an honorific inscription dedicated to Zeus Beudenos by Mysians from the village Emoddi (ca. 171-161 BC); the epitheton of Zeus was already attested in Saittai (Lydia). [AC]

202) G. Manganaro, Due studi di numismatica Greca, in ASNP, Ser. 3,20 (1990), p. 409-427 [BE 1992, 126. 192]: In a study of graffiti on coins (cf. G. MANGANARO, in $J N G, 1983$, p. 9-20; O. MASSON, in $R A, 1985$, p. 35-46) M. discusses some graffiti to which other scholars had attributed a religious character. In two coins regarded by O. MASSON (o.c.) as dedications to Artemis and Asklepios M. proposes to read personal names (Artamis, Aiglapios) [but see the remarks of O. MASSON, in $B E 1992,192]$; in the graffito $E B G R 1988,6$ M. reads the personal name Strobias, instead of the divine epitheton or name $M<\alpha>\tau \rho \circ \beta i \alpha$. A dedication to Zeus Lykaios (Himera?) implies the introduction of this cult from Arkadia to Sicily (5th c. BC). [AC]

203) M.T. Manni Piraino, Marsala, in Kokalos, 33 (1987) [1990], p. 25-26: Ed. pr. of an inscription on a painted, sepulcral stele (Marsala on Sicily, 2nd c BC):

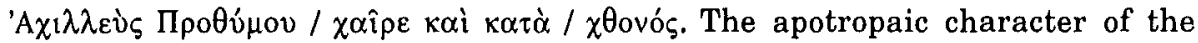
inscription is illustrated by the representation of two raised hands, left and right of the young man's portrait. The author believes that the deceased died very young and due to a violent cause. [ES]

204) M.T. Manni Piraino, Naxos, frammenti fittili iscritti, in Kokalos, 33 (1987) (1990), p. 27-45 [SEG 39, 1015]: Ed. pr. of a graffito on a vase (7,

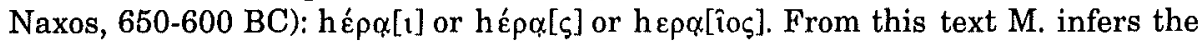
existence of a cult of Hera (Hera "guerriera"?) on the east side of the river Santa Venera. [ES]

205) M. Martelli, La stipa votiva dell'Athenaion di Jalysos: Un primo bilancio, in S. Dietz - I. Papachristodoulou (edd.), Archaeology in the Dodecanese, Copenhagen, 1988, p. 104-120 [SEG 38, 783]: M. reports the find of ca. 200 graffiti on vases found in the votive deposit at the sanctuary of Athena in Ialysos (6th-4th c.); they bear various dedicatory formulas [see already $E B G R$ 1989, 27]. [ES]

206) A.A. Maslennikov, Les graffiti et les dipinti du cap Zjuk, in KSIA, 191 (1987), p. 45-53 [BE 1990, 594]: Mention of a malediction on a sherd (cape

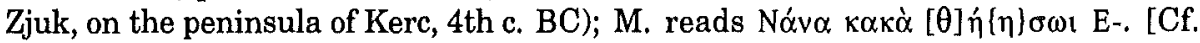
J. VINOGRADOV, in $B E 1990,594$; V. suggests the reading $v \alpha(i), v \alpha(i), \kappa \alpha x \alpha$ 


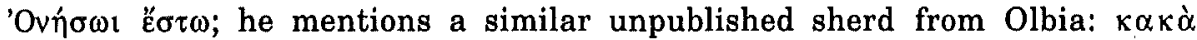

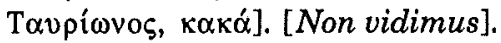

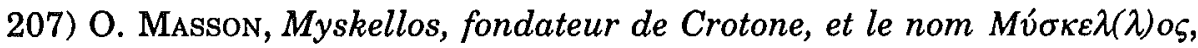
in $R P h, 63$ (1989), p. 61-66 [SEG 39, 550]: M. discusses the dedication to Artemis Пробко́ $\alpha$ (the 'Overseer', Apollonia in Illyria, $S E G 36,559$ ). The inscription is to be dated about 250-200 BC. [ES]

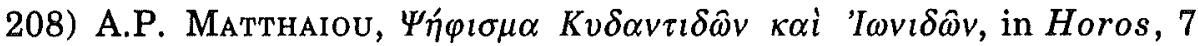
(1989), p. 7-15: Ed. pr. of a common decree of the Attic demes of the Kydantidai and Ionidai in honour of a priest of Herakles (331/30 BC); the decree attests for the

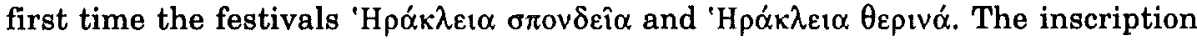
was set up at a local sanctuary of Herakles. [AC]

209) H.B. Mattingly, Some fifth-century Attic epigraphic hands, in $Z P E$, 83 (1990), p. 110-122 [BE 1991, 229]: The attribution of a series of 5th-c. documents to certain stone-masons offers an additional criterion for the date of inscriptions, some of them of significance for religious matters. $I G \mathrm{I}^{3} 130$, to be dated ca. 429/8, probably honours Zeus Soter, after the Athenians had escaped a Spartan attack on Piraeus; the Eleusis-decrees can be dated in the summer of 431 ( $\left.I G \mathrm{I}^{3} 58\right)$; the sacrificial calendar of Thorikos $(S E G 33,147)$ should be dated around 420 BC. [AC]

210) L. Mendoni, More inscriptions from Keos, in ABSA, 84 (1989), p. 289-296 [SEG 39, 870. 876; $B E$ 1990, 292]: Ed. pr. of a dedication to Hermes Prytaneios by a magistrate after his term of office (3, Poieessa, Keos, 5th c. BC); M. also restores $S E G 14,548$ as a similar dedication. [AC]

211) L. Mendoni, Addenda et corrigenda ad inscriptiones Ceae, in Poikila, p. 287-300: 1) Ed. pr. of a dedication to Apollon, found in the temple of Apollon in Karthaia; the dedicant belonged to an important family of Karthaia. 2) Restoration of the name of the dedicant in IG XII 5, 619 (100 BC/100 AD). 3) On the base of a black-figured Attic skyphos bearing a dedicatory inscription to Dionysos ( $S E G 25,960,4$ th c. BC) M. was able to read another graffito possibly related to this dedication. [ES]

212) G. Minallov, Epigraphica et linguistica, in Linguistique Balka-

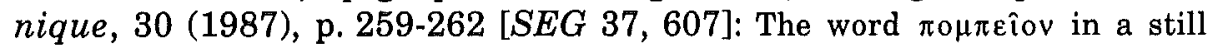
unpublished inscription from Dionysopolis (4th c. BC) characterizes a building, where objects carried during prossessions were deposited. The city of Dionysopolis gave to a King Kotys a shrine of Aphrodite to be used as a $\pi \circ \mu \pi \varepsilon i o v$. [AC]

213) M.M. Miles, A reconstruction of the temple of Nemesis at Rhamnous, in Hesperia, 58 (1989), p. 133-249 [SEG 39, 216; BE 1990, 102]: M. republishes and discusses (p. 236-239) the dedicatory inscription for the deified Livia (Rhamnous, IG II ${ }^{2} 3242$ ). She dates the text to $\mathrm{AD} 45 / 6$ bringing it in connection with the repairs to the temple of Nemesis; the imperial cult was integrated in the traditional cult of Nemesis. [AC] 
214) E. Miranda, Un decreto consolatorio da Neapolis, in Puteoli, 12/13 (1988/89) [1991], p. 95-102: Ed. pr. of a consolatory decree (Puteoli, 1st c. BC); notice the mention of a laudatio funebris and the honours bestowed on the deceased benefactor; he was awarded a golden garland, a statue, and probably the burial place. $[\mathrm{AC}]$

215) E. Miranda, Iscrizioni greche d'Italia. Napoli, Roma, 1990 [BE 1991, 686]: In the first volume of the corpus of the Greek inscriptions of Italy M. reedites and comments on the inscriptions from Neapolis, almost all of which were included in $I G$ XIV. The first part contains dedicatory inscriptions (1st-3rd c. AD) to the following deities: the Dioskouroi and the Polis (1), the Thessalian hero Eumelos, eponymus of a local phratry (2), Hebon, a deity attested only in Neapolis (3. 4), Herakles (5), Isis, Apollon, Horos, and Harpokrates (6), the Tyche of Neapolis (8),

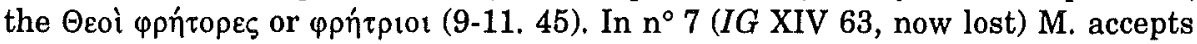
the reading of the ed. pr. (G.S. CAPACcIo, Napoli greco-romana, Napoli, 1905,

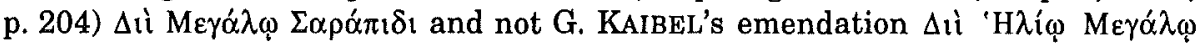
$\Sigma \alpha \rho \alpha ́ \pi 1 \delta$ 1. Also notice the participle $\lambda \alpha v \kappa \varepsilon \lambda \alpha \rho \chi \eta^{\prime} \sigma \alpha \varsigma$, which appears in the cursus honorum of the dedicants to Hebon (3-4); the exact function of the laukelarchos cannot be inferred from these texts; he may have been the priest of Hebon. The fourth part of the volume contains inscriptions concerning the phratries, which still existed in the imperial period; notice the names Artemisioi, Hermaioi, Aristaioi etc. A text concerning a foundation (43; B. LAUM, Stiftungen in der griechischen und römischen Antike, Berlin-Leipzig, 1914, vol. 2, $\mathrm{n}^{\circ} 212$ ) and an honorary decree of

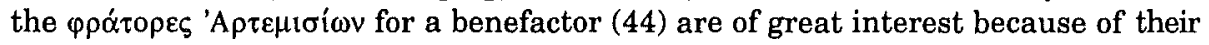
references to the cults and the organisation of the phratries. A priest ([ $\delta \dot{\alpha} \beta \beta$ íov?]) of the $\theta$ coi $\varphi \rho \eta$ ítor is mentioned in $\mathrm{n}^{\circ} 45$. [ES]

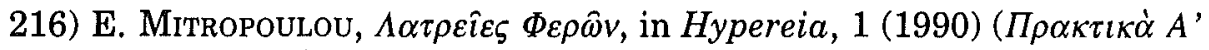

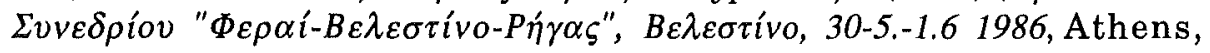
1990), p. 71-81: Survey of the cults attested in Pherai (Thessaly): Aphrodite, Artemis Pherhaia, Asklepios, Athena, Demeter, Dioskouroi, Enodia, Hekate, Helios, Hera, Herakles, Isis, Kybele, Sarapis, Themis, Zagreus, Zeus (Meilichios, Thaulios). [AC]

217*) F. Mora, Prosopografia Isiaca. I. Corpus prosopographicum religionis Isiacae. II. Prosopografia storica e statistica del culto Isiaco (EPRO, 113), Leiden, 1990 [BE 1992, 245]: Prosopography of devotees and officials of the Isis cult in Delos (I), the Greek Orient (II), Italy (III), the Danubian provinces (IV), the Western provinces (V), and Africa (VI); analysis of the data (participation of women, deities associated with the cult of Isis, aretalogies). [AC]

218) L. MoReTt, Incriptiones Graecae Urbis Romae. Fasciculus quartus (1491-1705). Revidenda potiora, Rome, 1990 [BE 1991, 110]: The new fascicle of IGUR contains a few new texts (marked with an asterisk). The first part is dedicated to a large group of inscripions of artists and on works of art (1491-1651). M. discusses the funerary epigram for Q. Iulius Miletos who died in Rome, where he had traveled from Lydia to watch the ludes saeculares in $\mathrm{AD} 204$ (1567 = IG XIV

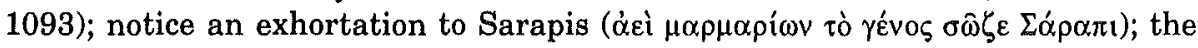

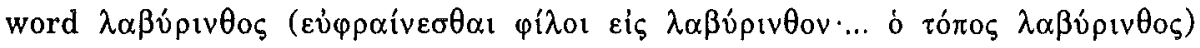


had been interpreted by W. AmELing ( $S E G 36,930)$ as a reference to the underwold and the tomb; M. rejects this vew, agreeing with L. ROBERT that the word denotes a building with banqueting rooms. Other texts: an inscribed basis of the statue of a priest, probably brought to Rome from Athens (1572, 2nd c. AD); signatures of the sculptor and high priest Fl. Zenon of Aphrodisias (1594-1598) [cf. infra $\mathrm{n}^{\circ} 265$ ]; an inscribed marble tablet with a fragmentary text referring to the murder of Aegisthos and Klytemnestra by Orestes (1652, 3rd c. AD; cf. two other

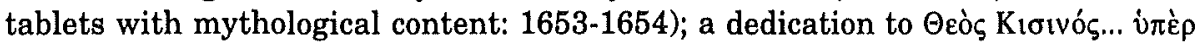

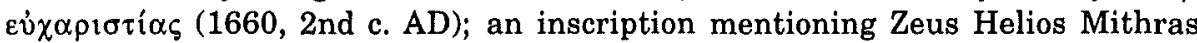

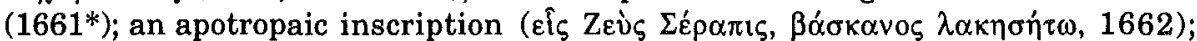

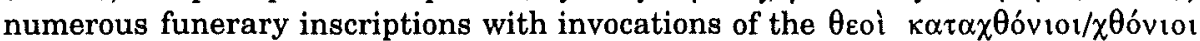
(1663. 1664. 1667. 1669. 1670. 1672. 1673. 1674. 1681. 1682. 1684. 1686. 1693. 1697; cf. 1702: $\theta$ eoî (1678. 1692); the funerary epigram for Ausonius, priest of Fortuna (1700, 2nd c. $\mathrm{AD}$ ); the long funerary epigram of a boy, describing the calamities given to him by

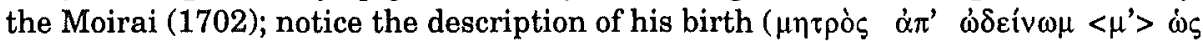

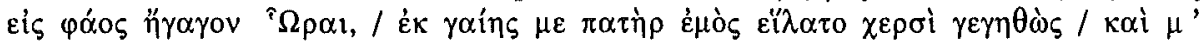

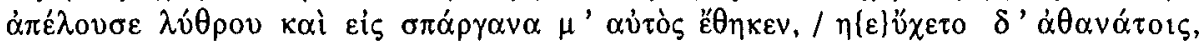

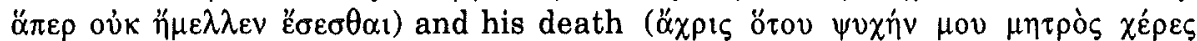

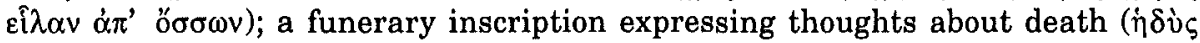

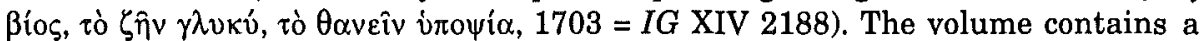
list of additions and bibliographical references concerning texts published in IGUR I-III. [AC]

219) M. Moussu - J. Ebert, Weitere Inschriften aus Emesa und seinen Nachbargebieten, in Philologus, 134 (1990), p. 93-102 [BE 1992, 194]: Ed.

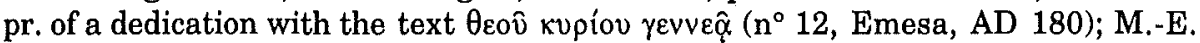
translate "to the family of the deified ruler" (sc. Marcus Aurelius). [O. MASson, in $B E 1992,194$ rightly points out that it is a dedication to the Syrian god Genneas]. [AC]

220) A.M. NAgy, Pilula crystallina, in Bulletin du Musée Hongrois des Beaux-Arts, 73 (1990), p. 11-19 [BE 1992, 122]: Ed. pr. of a crystal ball (unknown provenance, 2nd/3rd c.), probably an amulet. Divine symbols (crescent

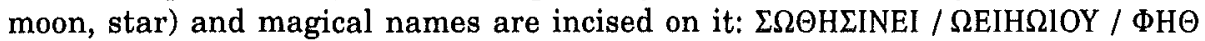
or $\Psi \mathrm{H} \Theta$ (contraction of the Coptic article with the name Seth?) / BAINX $\Omega \Omega \Omega X$ (translation of an Egyptian expression meaning 'the soul of the dark'). The amulet invokes the gods of the Sun and the Moon. [The name (or word) on the first line might contain a form of the verb $\sigma \omega \zeta_{\zeta} \in v$; the second line contains a sequence of vowels common in magical texts; cf. F. DoRNSEIFF, Das Alphabet in Mystik und Magie, Leipzig-Berlin, 1925, p. 35-51, 57-60; EBGR 1988, 47]. N. discusses the spherical shape of the amulet (symbol of the universe) and adduces numerous parallels for the use of inscribed or decorated rock-crystal balls in magic. [On the power attributed to rock-crystal see R. HALLEUX - J. SCHAMP, Les lapidaires grecs, Paris, 1985, p. 301-302]. [AC]

221) G. Nenci, Una dedica di Creso a Delfi?, in ASNP, Ser. 3,20 (1990), p. 367-370 [BE 1992, 272]: Ed, pr. of an inscribed bronze-stand with a dedicatory inscription, written in the Korinthian alphabet (early 6th c.), found in Delphi in the deposit containing a part of the dedication of Croesus. The inscription reads: hí $\pi \pi \circ \varsigma$ 


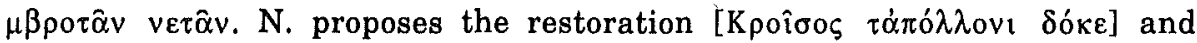
discusses the possible character of the dedication; he speculates that i $\pi \pi 0$ were not sacrificial animals, but pieces of jewlery (cf. HESYCH., s.v. i $\pi \pi i \sigma \kappa o s)$, dedicated by Lydian women (cf. HEROD. I 50,1). [See the objections of J. BOUSQUET, in BE 1992, 272]. [AC]

222) G. Neumann, Beiträge zum Kyprischen XII, in Kadmos, 29 (1990), p. 157-168: N. discusses the syllabic dedicatory inscription ICS 286 (Golgoi?,

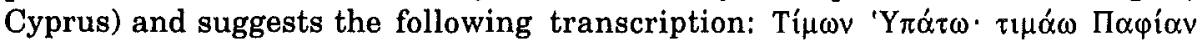

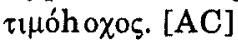

223) I. Nikolaou, Inscriptiones Cypriae alphabeticae XXIX, 1989, in $R D A C, 1990$, p. 173-179 [BE 1991, 610]: Ed. pr. of a cippus dedicated to Hestia Boulaia (p. $178 \mathrm{n}^{\circ} 30$, Paphos, 1st c. AD); notice the personal name 'Anó $\lambda \lambda \omega \varsigma$ or 'A $\pi 0 \lambda \lambda \hat{\omega} \varsigma_{\text {(p. 173, }}^{\circ}$ 2) [cf. O. MASSON, in BE 1991, 610]. [AC]

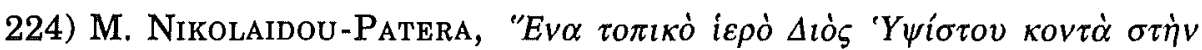

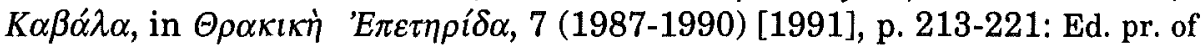
an inscription dedicated to Zeus Hypsistos by a smith with the Thracian name Tarsas, found near an ancient quarry (Chalkeron, near Kavala, Thrace, 2nd c. AD); another dedication to the same god (1st c. AD) had been found at the same place in 1935. [AC]

225) J. NolLÉ, Epigraphische und numismatische Notizen 9: Zu der neuen Stele aus dem Museum von Aydin, in $E A, 15$ (1990), p. 121-126 [BE 1991, 525]: See $E B G R$ 1988, 104, $B E$ 1990, 704 and the remarks of C. BRIXHE A. PaNAYotou, in $B E$ 1992, 432. [AC]

226) R. ÖzGAN, 1988 Knidos Kazisi ön Raporu, in KST, 11.2 (1989), p. 167 175 [BE 1991, 548]: Mention of an honorary inscription of a runner (Kó $\rho v \varepsilon \alpha$ $\delta \rho \circ \mu \eta \tilde{\sigma} \sigma \nu \tau \alpha)$ at the festival of Apollon Karneios (Knidos, Hell.). [AC]

227) A.N. Orkonomides, The Athenian cults of the three Aglauroi and their sanctuaries below the Acropolis of Athens, in AncW, 21 (1990), p. 11-17: O. distinguishes three mythical Aglauroi and discusses the honorary decree for a priestess of Aglauros found in situ under the large cave on the east side of the Acropolis (SEG 33, 147, ca. 247-245). This Aglauros is probably Kekrop's daughter, who opened Athena's chest. Her priestess is praised for offering the sacrifices to Aglauros, Ares, Helios, the Horai, Apollon, and the other gods on the festival Eisiteria and for taking care of the orderly celebration of a $\pi \alpha v v v x i$ s. The decree was voted after a report of 'the son of the priestess'; $O$. asks himself why the priestess is called 'the daughter of Polynikos'; although she had a son, the name of her husband is not given. He speculates that the expression 'the son of the priestess' might be a special cult title [!]. [AC]

228) A.N. Oikonomides, The shrine of Makaria in Athens, in AncW, 21 (1990), p. 19-20 [BE 1991, 260]: Discussion and minor restoration of an Attic epigram ( $S E G$ 26, 246, 2nd c. $A D$ ). According to $O$. it was dedicated by the Athenian ephebes to Makaria, the daughter of Herakles, who had sacrificed herself to save Athens. [AC] 
229) J.H. OLIVER, Greek Constitutions of Early Roman Emperors from Inscriptions and Papyri, Philadelphia, 1989 [SEG 39, 1776; BE 1990, 10]: This corpus of imperial letters, edicts, subscripts, instructions etc. in Greek inscriptions and papyri (edition, translation, and brief commentary) contains many documents of religious interest (no new texts): Casesar's decree about the violation of graves (2), a letter written by Claudius to the association of hymnodoi (21), a fragmentary edict of Claudius concerning the Asklepieion of Epidauros (26), a letter written by Domitian concerning the Pythia of Delphi (42), a letter written by Trajan releasing a citizen of Aphrodisias from a liturgy at the temple of the koinon of Asia in Smyrna (48), letters written by Hadrian on Amphictyonic affairs (75. 76), Hadrian's letter to Miletos accepting the office of prophetes at Didyma (87), a letter sent by Antoninus Pius to Balboura about the new music contest established by Meleagros (159), a rescript of Marcus Aurelius and Lucius Verus concerning the images of emperors carried in processions (170), a letter written by two emperors about athletes unwilling to participate in the Panhellenic contest (188; cf, 245), a letter written by Commodus to the Eumpolpidai accepting their proposal to become their archon (206), the confirmation of the privileges of Delphi by Septimius Severus and Caracalla (215), letters written by Julia Domna and Caracalla concerning the Artemisia and the neokoreia of Ephesos (264-266), a letter written by Macrinus and Diadumenianus to Miletos referring to their ceremonial greeting by officials carrying a cult image of Apollon Didymaios (273); several letters written by emperors with their refusal of divine honours (Tiberius, Gytheion: 15; Claudius, Thasos: 23; Hadrian, Achaia: 78); two documents referring to contests established in commemoration of victories (218. 219); letters or edicts of various emperors to the associations of Dionysiac artists (24. 29. 32. 47. 96-104. 157-158. 168. 212. 225. 277), athletes (37. 86. 128), and doctors (38). [AC]

230) E. Olshausen, Zwei unedierte Inschriften aus dem Museum von Samsun, in AST, 6 (1988), p. 272 [SEG 38, 1280]: Ed. pr. of a dedication of a

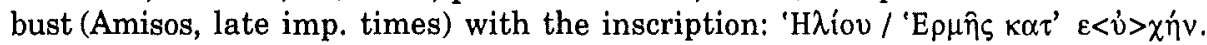
The text should either be regarded as a dedication to Helios by a person named Hermes, or as a dedication to a unmentioned deity by Hermes, son of Helios (suggested by D. FRENCH, apud ed. pr.). [ES]

231) A. ONASOGLOU, in $A D, 40 \mathrm{B1}$ (1985) [1990], p. 88: An inscribed sherd of an

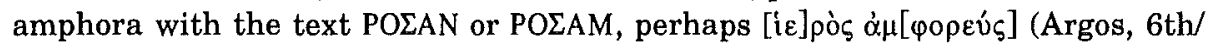
5th c.). [AC]

232) M. Osanna, Sui culti arcaici di Sparta e Taranto. Afrodite Basilis, in $P P, 45$ (1990), p. 81-94: On some fragmentary graffiti on vases from Sparta (SEG 2,133-136. 151; 11,670) O. restores the divine epithet Basilis, instead of a personal name; this epitheton should be attributed to Aphrodite. Hesychios attests the cult of Aphrodite Basilis in Taras, a Spartan colony. In Sparta the cult place of Aphrodite Basilis can be located on the Acropolis; this location as well as the epithet of the goddess show that this cult had besides its chthonic character also a political one. [ES]

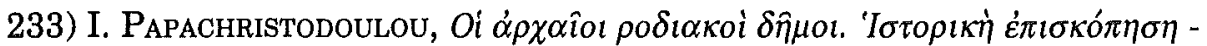
' $H$ 'I $\alpha \lambda v \sigma i \alpha$, Athens, 1989 [SEG 39, 719-724. 842-843; BE 1992, 337]: In his study on the history and political institutions of Rhodos P. focusses on Ialysos and 
its local demes (topography, archaeological and epigraphic finds). P. gives a full catalogue of the already published and new inscriptions of Ialysos, classified according to the demes. Several new inscriptions: A dedication to Zeus Atabyrios (2nd c. BC?, p. 197, $\mathrm{n}^{\circ} 8$ ); it is the first attestation of this cult in Ialysos; an inscription mentioning priests (of Apollon Erethimios?), who cared for the restoration of a building (1st c. $B C$ ?AD, p. 183-186 $n^{\circ} 29$ ); a fragmentary inscription mentioning Apollon Erethimios and Artemis (p. $187 \mathrm{n}^{\circ} 31$ ); reedition of a dedication to the Dioskouroi by an epistates (Karpathos, 2nd/1st c., p. 160, n ${ }^{\circ} 7$ ) [SEG 27, 482]. Notice a useful catalogue of all the known cults of Ialysos (p. 152). [ES]

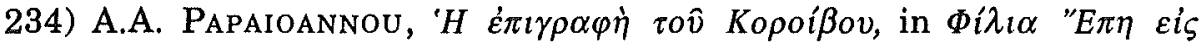

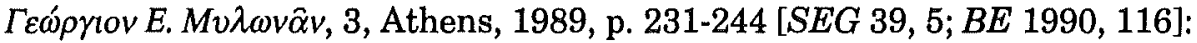
The Attic decree concerning the establishment of the office of the epistatai in Eleusis should be dated to $431 / 1$; the Telesterion of Eleusis had already been built by that time. [K. CLINTON expresses the same view: supra $\mathrm{n}^{\circ}$ 63]. [AC]

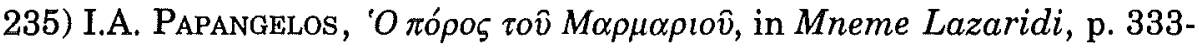
$356[B E$ 1991, 414]: Photo of an inscription (p. 354, fig. 6, Marmarion, East Macedonia). [M.B. HATZOPOULOS, in $B E$ 1991, 414 recognizes a boundary stone of a sanctuary of Artemis]. [AC]

236) I.A. Papapostolou, Monuments des combats de gladiateurs $\grave{a}$ Patras, in BCH, 113 (1989), p. 351-401 [SEG 39, 406]: Ed. pr. of a dedication to Hadrian Olympios (Patrai, after $132 \mathrm{AD}$ ) called Soter and Ktistes. This text may be connected with the construction of a newly discovered amphitheatre near the sanctuary of Nemesis. [ES]

237) A. Pariente, Chronique des fouilles et découvertes archéologiques en Grèce en 1989, in $B C H, 114$ (1990), p. 703-850: Mention of recent epigraphical finds: A new fragment permits the restoration of the dedicatory inscription commemorating the victory of Kasia from Elis at the quadriga race at the 200th Olympic games (p. 747, 748 fig. 59; cf. I.Olympia 233, AD 21); a dedicatory inscription to Theos Heros Auloneites from his sanctury at Kipia (Macedonia) [cf. supra $\mathrm{n}^{\circ}$ 170]. [AC]

238) C. Parisi Presicce, Nuovi altari nel santuario di Apollo a Cirene. Indagini preparatorie per la ricostruzione grafica delle fasi architettoniche dell'area sacra, in Archeologia Cirenaica, p. 121-155 [BE 1991, 675]: General presentation of the history of the sanctuary of Apollon in Kyrene. P. mentions a new altar dedicated to Panakeia (p. 124), whose cult was probably introduced from Kos, and comments on the cult of Asklepios in Kyrene. [AC]

239) S.J. Patrerson, Response to W. Brashear's note [supra $\mathrm{n}^{\circ} 40$ ], in $H T R, 83$ (1990), p. 339-340: P. draws attention to three problems related to A. DELATTE's view that a relief stele from Argos with a representation of Selene and a magical text [supra $\mathrm{n}^{\circ}$ 40] is related to Gnosticism: 1) The astrological symbolism was not only used by the Gnostics; 2) it is not certain whether the inscription contains seven words (according to DELATTE the names of the seven heavenly archons) or eight words ( $\alpha \beta \omega \theta \varepsilon \rho \sigma \alpha \varsigma$, not $\alpha \beta \omega \theta \varepsilon \rho \sigma \alpha \varsigma)$; 3) except for the name Sabaoth, no other name of the inscription is so far attested as a name of a Gnostic 
archon. P.'s alternative interpretation regards these words as epitheta of Selene, Queen of Heaven and Lord of the Universe. [AC]

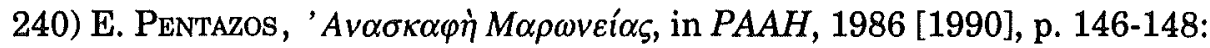
Mention of a stele dedicated to Zeus and King Philipp Soter, i.e. Philipp V (Maroneia, 3rd/2nd c.) [ = SEG 37,612]. [AC]

241*) P. Perlman, Acting the she-bear for Artemis, in Arethusa, 22 (1989), p. 111-133 [SEG 39, 1714]: Discussion of the cult of Artemis in Brauron. $P$. argues that the small cave and the later adyton served as the places, where the maiden $\ddot{\alpha}$ pkto The she-bear was a symbol of motherhood and wilderness; her reproductive cycle was adopted as a paradigm for female initiation rites. In a postscript $P$. discusses the cult of Artemis Katagogis in Kyrene (SEG 9,13). She argues that the epitheton Katagogis is not related to a periodic withdrawal and return, but should be

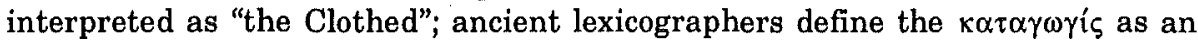
article of female clothing (cf. the analogous epitheton of Artemis Chitone) [on the latter see $E B G R$ 1988, 63]. This epitheton and the fact that the priestess of Artemis Katagogis is called öpкоৎ ( sic) brings this cult in connection with that of Artemis in Brauron. P. associates with Artemis' cult the lex sacra of Kyrene (LSCG Suppl. 115), which contains a sequence of ritual prescriptions for women arranged according to their age and situation (A 74-80: pubescent girls; B 1-14: brides; B 1523: pregnant women). The Nymphaion of Artemis, where the brides and the pregnant women should go (B 9. 15), may be identified with the adyton of the 5thc.-temple of Artemis in the sanctuary of Apollon. [AC]

242*) P. Perlman, The calendrical position of the Nemean games, in Athenaeum, 67 (1989), p. 57-90 [SEG 39, 343; BE 1990, 225]: A reexamination of the literary and especially the recent epigraphic evidence concerning the calendrical position of the Nemean games strengthens the view that the games were celebrated during the month Panamos; perhaps they were scheduled so as to coincide with the new moon. P. argues [with less conclusive arguments] that Panamos occupied the calendrical position of August-September; the following months (Agyeos, Karneios, Hermaios) correspond respectively to SeptemberOctober, October-November, and November-December. [AC]

243) M. Peters, Indogermanische Chronik 33, G. Altgriechisch, in Sprache, 33 (1987), p. 227-329 [SEG 38, 1014]: Linguistic contribution to the lex sacra from Assos (p. 260 G 150; $E B G R$ 1988, 76); in the inventory (?) of a sanctuary

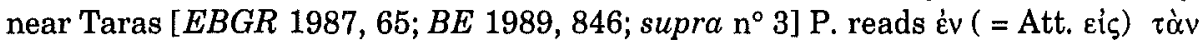
Folkíav (p. $260 \mathrm{G} 143$ ). [AC]

244*) H. Petersmann, Le culte du Soleil chez les Arabes selon les témoignages gréco-romains, in Arabie préislamique, p. 401-412 [SEG 39, 1834]: A thorough study of the cult of the Sun in Arabia on the basis of the Greek and Latin literary and epigraphic sources. Three deities with solar aspects are documented in Greek inscriptions: 1) $A \lambda \lambda \alpha \theta$, a celestial goddess identified by the Greeks and the Hellenized Arabs with Athena (SEG 4, 164) and Ourania

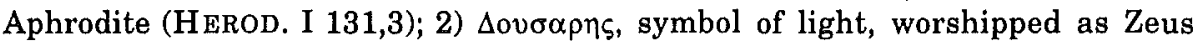

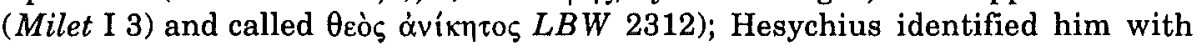


Dionysos, the Greek god of vegetation par excellence. 3) A $\hat{u} \mu \circ \varsigma$, god of the heat and drought in the Hauran, assimilated with Zeus and Helios ( $L B W$ 2394; I.Délos 2321); this name, which usually appears in the genitive, was either an indeclinable name of a local god or the Greek translation of a Semitic name (adjective $\alpha \hat{v} \circ \zeta$ and the suffix $-\mu \circ \varsigma)$; in the second case it can be translated as the god "celui de la chaleur". [ES]

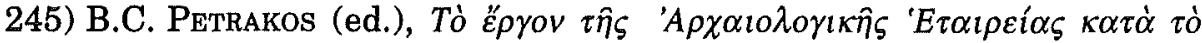
1989, Athens 1990: Report of the activities of the Archaeological Society at Athens with reference to numerous new epigraphic finds. Rhamnous: Three new dedicatory inscriptions to Zeus Soter und Athena Soteira by strateges (Hell.); their dedications were probably bronze torches commemorating the lampadephoria in honour of these deities (p. 6); a dedication to Demeter and Kore by a strategos (p. 6); an honorific inscription mentions the dedication of a painted portrait of a general in the Nemesion (p. 7); an honorific decree of Rhamnous for Antigonos Gonatas referring to a sacrifice offered to the Macedonian king on the 19th Hekatombaion, on the day of the gymnikos agon of the Great Nemesia (p. 8, ca. 261). Messene: An inscription on a pillar of a hall in the area of the Sebasteion mentions the priest of Zeus Ithomatas (imp., p. 35). Torone: Mention of a graffito on a sherd naming Athena (sanctuary of Athena at Lekythos, p. 76) [cf. infra $\mathrm{n}^{\circ}$ 153]. [AC]

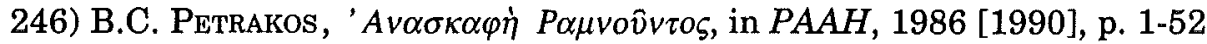
[BE 1991, 290]: Mention of new inscriptions found at the sanctuary of Nemesis, the fortress at Rhamnous, and the sanctuary of Amphiaraos. Sanctuary of Nemesis: A marble vase dedicated to Nemesis in fulfillment of a vow (p. 5, 3rd c. AD). Fortress: A fragmentary choregic inscription, probably referring to a local festival (p. 16-17, $\mathrm{n}^{\circ}$ 6). Amphiaros sanctuary: A relief dedicated to Amphiaraos with representation of the hero, his snake, and five persons. [AC]

247) G. PerzL, Epigraphische Funde aus Lydien, in EA, 15 (1990), p. 49-72 [BE 1991, 500.513]: Ed. pr. and restorations of inscriptions from Lydia. 4) On the first line of the epitaph $T A M V 2,1409 \mathrm{P}$. reads the invocation 'A $\gamma \alpha \theta$ ò $\Delta \alpha$ í $\mu \omega v$ (Magnesia of Sipylos). 20) Ed. pr. of a fragmentary inscription, probably concerning a foundation dedicated to or put under the protection of a deity; any offender would be charged on impiety (area of Saittai?, 2nd/3rd c.). 21) Mention of a Kybele-relief (without an inscription). 32) Dedication of a statue of Zeus Soter to Emperor Trajan and an anonymous katoikia (AD 116/117). [AC]

248) F. PIEJko, To the inscriptions of Labraunda, in OpAth, 18 (1990), p. 133-156 [BE 1991, 529]: $P$. tries to restore a series of fragmentary inscriptions found at the sanctuary of Zeus Labraundos (J. CRAMPA, Labraunda III. The Greek Inscriptions 1-2, Stockholm, 1969-1972, $\mathrm{n}^{\circ}$ 1-10. 12. 42-44. 46-48. 53. 54. 61. 62. 88); numerous texts belong to two dossiers of documents (letters, decrees etc.) which concern the history and the privileges of the sanctuary and were published in the $2 \mathrm{nd} / 1$ st c. $\mathrm{BC}$ and 1st c. $\mathrm{AD}$. Some of P.'s suggestions: $\mathrm{N}^{\circ} 44$ refers to the immunity of the priest of Zeus Labraundos; $n^{\circ} 46$ is a letter (of the Seleucid official Zeuxis?) commanding the troops stationed near the sanctuary not to harm the sanctuary and its visitors; $n^{\circ}$ 53-54 are decrees of Mylasa and the Karian cities concerning a festival commemorating the failure of an attempt on Maussolus' life; $n^{\circ} 61$ is a 
rescript for the protection of the sacred land. [Many restorations are questionable]. [AC]

249) D.T. PotTs, The Arabian Gulf in Antiquity, Oxford, 1990: Discussion of the inscriptions of Failaka/Ikaros (vol. II, p. 183-196): a dedication to Zeus Soter, Poseidon, and Artemis Soteira (late 4th c.), the letter of Ikadion concerning the sanctuary at Ikaros [cf. supra $\mathrm{n}^{\circ} 47$ ), and an altar dedicated by soldiers [EBGR 1988,$145 ; 1989,51$; cf. $B E 1990,305$ ]; no new restorations or readings. P. suspects that the sanctuary (of Zeus Soter and Artemis Soteira?) was relocated because of its vicinity to the shore (p. 192). The 'fortress' on the island lkaros was primarily an enclosure for the temples inside, rather than defensive in nature. [AC]

250) P. Properzio, New light on the cults of Artemis and Apollon in Marseilles, in R.F. SutTon, Jr. (ed.), Daidalikon. Studies in Memory of Raymond V. Shoder, S.J., Wauconda, 1989, p. 295-299 [SEG 39, 10821083]: Restorations of two inscriptions from Massalia: 1) Diktya, to whom an inscribed vase was dedicated, should be identified with Diktynna = Artemis (IG XIV 357, 1st c. BC). 2) IG XIV 2464 (1st c. BC/AD) is a dedication to Apollon [Apotro]paios, whose cult is probably connected with the festival Thargelia. [R.S. STROUD, in $S E G 39,1083$ suggests reading $\Pi \alpha 1 \omega\left[{ }^{2} 1\right]$; cf. also the remarks of $\mathrm{H} . \mathrm{W}$. PLEKET, ibid.]. [AC]

251) G. Pugliese Carratelli, Decreti di Iasos in onore di giudici stranieri, in $R A L$, Ser. 8, 44 (1989) [1991], p. 47-55 [BE 1992, 442-447]: Ed. pr. of four honorific decrees for foreign judges and a fragment belonging to the similar decree I.Iasos 78. Notice the existence of a special fund of the neopoiai in

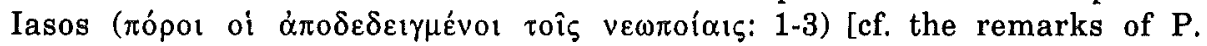
GAUTHIER, in $B E$ 1992, 443]; this fund was used among other things for the setting up of inscriptions. The honours for the judges from Myndos should be proclaimed at the festival Dionysia in their native city (1); the inscriptions were to be set up in the sanctuaries of Apollon at Myndos (1), of Artemis (1), Zeus and Hera (2-4) at Iasos. [AC]

252) W. RADT, Zwei augusteische Dionysos-Altärchen aus Pergamon, in Festschrift Inan, p. 199-209 [BE 1992, 81]: Ed. pr. of two altars dedicated by the head of a Dionysiac association ( $\alpha \rho \times 1 \beta 0 v \kappa o ́ \lambda \circ \varsigma)$; the first altar, with representation of grapes and a kantharos, is dedicated to Dionysos Kathegemon; the second is dedicated to Augustus and bears representations of oak-branches, capricorn (Augustus' sign of the zodiac), and cornucopia (Pergamon, ca. $27 \mathrm{BC}$ ). The altars probably stood in the 'Podiensaal', which may have been the seat of the techniton synodos at Pergamon; in Hellenistic times this building was probably dedicated to the royal cult, since two dedications to Attalos Soter were found near by. Dionysos was a patron god of the Attalid dynasty. [AC]

253*) G. Ragone, Il tempio di Apollo Gryneios in Eolide. Testimonianze antiquarie, fonti antiche, elementi per la ricerca topographica, in B. VIRGILIO (ed.), Studi ellenistici III, Pisa, 1990, p. 9-112: Exhaustive study of the literary, archaeological, and epigraphic testimonies for the oracle of Apollon Gryneios (Myrina); discussion of the dedicatory inscriptions addressed to Apollon Christerios (p. 10-21); study of the sources on the topography of the sanctuary and 
the sacred grove (p. 3-68, 86-92); reconstruction of the temple (represented on coins of the imperial period, p. 68-74); collection of inscriptions (mostly leges sacrae) referring to sacred groves and their protection (p. 92-94) [cf. B. JORDAN - J. PERLIN, On the protection of sacred groves, in Studies Presented to Sterling Dow, Durham, 1984, p. 153-160]; analysis of the only oracle of Apollon Gryneios preserved on an inscription (G.E. BEAN, in $J H S, 74,1954$, p. 85-87 $\mathrm{n}^{\circ} 21$ ); the oracle is given to Kaunos and concerns the cult of Leto, Apollon, and Zeus Patroios (p. 94-112). [AC]

254) K. REBER, Vorbericht über die Grabungen der Schweizerischen Archäologischen Schule im Haus IV von Eretria, in AK, 33 (1990), p. 111-114: An inscribed stone slab belonging to an altar for the cult of Arsinoe Philadelphos (ca. $270 \mathrm{BC}$ ) was found in a private house in Eretria; the owner of the house may have had trade contacts to Egypt. [AC]

255) M. Reddé, Le trésor de Douch, in CRAI, 1989, p. 427-445 [BE 1990, 168]: Presentation of a treasure of golden objects found at the sanctuary of Isis and Sarapis in the oasis Khargeh (Douch = Kysis, Egypt, imp.). A crown supporting a statuette of the enthroned Sarapis is probably a corona analemsiaca, i.e. the crown given to the priest at entering upon his office and carried by him on special

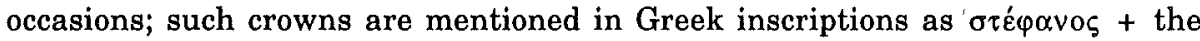
name of the respective deity. [AC]

256) G. Rethemiotakis, in $A D, 39$ B (1984) [1989], p. 297 [ $B E$ 1992, 138]: Mention of a lead object (cover of a box?) with a representation of Zeus Ammon and the inscription Zev́s (Gortyn). [AC]

257) J. Reynolds, Some inscriptions of Roman Ptolemais, in Archeologia Cirenaica, p. 65-81 [BE 1991, 678]: R. gives an overall picture of the contribution of inscriptions to the history of Roman Ptolemais; on p. 71 she mentions the texts concerning the imperial cult, among them an unpublished altar dedicated to Oeoi $\Sigma \varepsilon \beta \alpha \sigma$ roí. [AC]

258) J. REYNOLDS, Inscriptions and the building of the temple of Aphrodite, in C. Roueché - K.T. ERIM (edd.), Aphrodisias Papers: Recent Work on Architecture and Sculpture, Ann Arbor, 1990, p. 37-40: Discussion of the epigraphic evidence on the building of Aphrodite's temple at

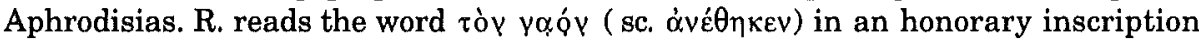
for Zoilos, the priest of Aphrodite (J. REYNOLDS, Aphrodisias and Rome, London, $1982, n^{\circ} 37$, late 1st. c. $\mathrm{BC}$ ), and argues that the temple's construction began in the triumviral period; later inscriptions (some of them still unpublished) show that the construction probably continued into the reign of Tiberius. Several (partly unpublished) texts refer to other structures in the precinct of Artemis (a colonnade, water basins, a kitchen, and a banqueting hall, probably housing a copy of the cultstatue). $R$. mentions a recently found inscription recording the dedication of a gymnasium to Aphrodite (?), emperor Hadrian, and the Demos. [AC]

259) F. RICHARD, Les souverains en "theoi epibaterioi". Sur un aspect particulier du culte impérial, in Navires et commerces de la Méditerranée antique. Hommage à J. Rougé (CdH, 33, 1988), Lyon, 1989, p. 441-

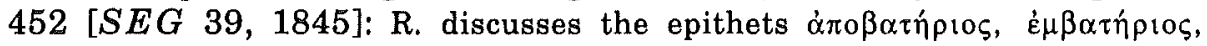


$\varepsilon \dot{\pi} \iota \beta \alpha \tau$ ptos attributed to Roman emperors (August, Trajan, Hadrian) in Greek inscriptions (OGIS 309; IG IV 701; I.Erythrai 60. 207). After studying the origins of these cults and the respective rites $R$. argues that these epithets do not denote the (dis)embarkment of an emperor in a specific city, as suggested by L. ROBERT (OMS III p. 1439-1524), but refer to the hope of the seafarers for their safe (dis)embarkment. The attribution of these epithets to the emperors point to an aspect of the imperial cult with a long tradition in the provinces. [ES]

260) T. RITTI, Hierapolis di Frigia: Santuari $e$ dediche votive, in Anathema, p. 861-874: Survey of the religious life in Hierapolis of Phrygia with reference to the dedicatory inscriptions found in the sanctuary of Apollon Kareios (imp.). The new texts are marked with an asterisk. I) Dedications to gods (p. 866870): A dedication of a sanctuary (Dodekatheon) to Zeus Olympios, the Patrioi Theoi, Hadrian, the imperial family, and the Demos by Ti. Iulius Myndios on behalf of his wife, who was the priestess of the Dodekatheon $\left(4^{*}\right)$; dedication of two statues of Herakles (5); dedications to Apollon Archegetes (1, a statue of Tyche), Apollon (Tarsios?, 2), Apollon Pythios (3), Dionysos Kathegemon (6*, for the first time attested in Hierapolis), Men (7), and Zeus Bozios ( $8^{*}$, only here attested). Also notice an honorific inscription (9) for the neokoros of the tempel of Aphrodite Ourania, mentioning his votive offerings (representations of Erotes and Charites). II) Dedications of political character (p. 870-872): dedications to or in honour of emperors or members of the imperial family (1-4) and the Demos (2. 3. 4) dedications of statues of the Demos (5*.6, by his priest) and the Boule ( $\left.7^{*}\right)$. [AC]

261) D.W. Roller, Tanagran Studies I. Sources and Documents on Tanagra in Boiotia, Amsterdam, 1989 [SEG 39, 445]: Collection and short [usually insufficient] discussion of the sources on Tanagra; no new texts. The inscriptions include dedications to Zeus in Olympia (38. 58, 6th-5th c.), a document of the association of the Dionysiastai $(91,2 \mathrm{nd} / 1 \mathrm{st}$ c.), a list of victors at the Sarapieia with an account of the agonothetai $(92,1$ st $\mathrm{c}$. BC), and the decree concerning the consultation of the oracle at Delphi about the relocation of the sanctuary of Demeter and Kore (87, 3rd c. BC); R. gives the text reconstucted by P. RoESCH [no reference to LSCG 72]; this decree concerns the election of a commission and the financing of the construction. The inscription also includes a long list of the women who offered money and three inventories of dedicated clothes. In an appendix (p. 151-156) R. surveys the deities and heroes whose cult is attested in Tanagra: Achilleus, Amphiaraos, Aphrodite, Apollon, Artemis, Athena, Demeter, Dionysos, the Dioskouroi, Elepheron, Eunostos, Hekate, Hermes, Hestia, Kabeiroi, Kore, Kybele, Leto, the Muses, Orion, Pan, Peneleos, Sarapis, Themis, Tlepolemos, Zeus.

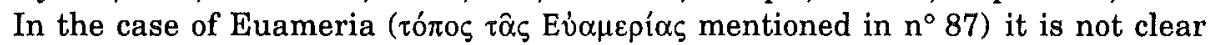
whether it is the name of a place or a deity. [AC]

262) D.W. Roller, Tanagran Studies II. The Prosopography of Tanagra in Boiotia, Amsterdam, 1989 [SEG 39, 445]: The prosopography of Tanagra contains a short discussion of theophoric names (p. 10) associated mostly with Apollon, Athena, Dionysos (cf. Backhos), Herakles, Hermes, and Zeus; other deities less commonly represented in the theophoric names of Tanagra are Aphrodite, Artemis, Asklepios, Demeter, Hekate, Helios, Hephaistos, Hera, and Poseidon; the cults of Asklepios, Helios, Hephaistos, Hera, and Poseidon are not attested otherwise in Tanagra. 26 names are related to the local mythology (p. 10-11). [AC] 
263) C. Rolley, Le sanctuaire d'Èvraiokastro. Mise à jour du dossier, in Mneme Lazaridi, p. 405-408: Recent finds - a dedication to Demeter Eleusinie Patroia and archaeological finds (kernoi, miniature vases etc.) - strengthen the view that the sanctuary at Evraiokastron (Thasos) was a Thesmophorion. [AC]

264) C. Roueché, Floreat Perge, in M.M. MacKenzie - C. Roueché (edd.), Images of Authority. Papers Presented to Joyce Reynolds on the Occasion of her Seventieth Birthday, Cambridge, 1989, p. 206-228: Detailed discussion of the acclamations for Perge (ca. AD 275/6, SEG 34, 1306). The first acclamation refers to the right of asylum awarded to the sanctuary of Artemis Pergaia; Perge is called the city "which alone has the right of asylum" (i.e. in Pamphylia). Other acclamations refer to the local festivals and contests as well as to the title of neokoros of the imperial cult given to the city under Vespasian. Also notice the invocation of the two city goddesses, Diana Ephesia and Diana Pergesia (i.e. Artemis Pergaia). This inscription is an interesting testimony for the contest between the cities of Asia Minor for the rank of a metropolis.

265) C. Roueché, Aphrodisias in Late Antiquity, London, 1989 [SEG 39, $1099 ; B E 1990,912]$ : R. republishes two texts mentioning descendants of highpriests (4-5, $\mathrm{AD}$ 253-260), two dedications of the high priest Zenon (11-12, 4th c. AD) [cf. supra $\mathrm{n}^{\circ} 218$ ], and a dedication to Theos Epekoos (10, 4th c. AD, EBGR $1987,95) ; R$. argues that this dedication is not Jewish. [AC]

266) G. Rougemont, Énigme à Delphes, in Hommage à G. Roux, p. 225229 [SEG 39, 463]: R. comments on C. KRITZAS' interpretation of the 'cippus of the Labyadai' containing religious prescriptions (CID I, 9 D. 29-43; cf. SEG 36, 520) and translates the part of the inscription in question. $K$. had read on the stone the father's name of Boupyga as Kasotos, whom he identified with the oracular fountain Kassotis; on the basis of this reading and identification Kritzas argued that the Labyades, originaly a clan of shepherds from Phanoteus, presided over the ancestral cult of Boupyga, even after it had become a public cult. R.'s main objection concerns the reading of the name Kasotos, which after a close study of the squeezes and the photos cannot be verified; R. reads KA.../OTOL (probably $\mathrm{KA}[\Sigma] / O T O \Sigma)$. [On the same subject of. supra $\left.\mathrm{n}^{\circ} 101\right]$. [ES]

267) G. Roux, Une querelle de préséance à Delphes, in ZPE, 80 (1990), p. 23-29 [BE 1991, 306]: R. offers a new interpretation of $S y l l^{3} 295$ (Delphi, ca. 340 BC) which concerns the privilege of promanteia awarded to Thurioi and Taras: Originally the citizens of Taras were given the privilege to consult the oracle before all other Italians; Thurioi demanded the same privilege, but a decision was delayed due to the construction works on the temple. After these works had been fulfilled and the oracle could function again, Agathon of Delphi and his brothers brought again the matter before the assembly of Delphi, which gave the promanteia $\pi$ po 'I $\tau \alpha \lambda \omega \tau \tilde{\omega} v \pi \alpha \dot{v} \tau \omega \nu$ to both cities; in case that a Tarantine and a Thurian would wish to consult the oracle at the same time, the order would be decided by drawing lots. [But see the critical remarks of L. DUBOIS, in $B E$ 1991, 306]. [AC]

268) M.C. SAHIN, Die Inschriften von Stratonikeia. Teil II, 2: Neue Inschriften und Indices (IGSK, 22,2), Bonn, 1990 [BE 1990, 24]: The last part of the corpus of Stratonikeia includes inscriptions found since 1977; all the 
texts have already been published by E. VARINLIOĞLU [EBGR 1989, 181; cf. the restorations and remarks of P. GAUTHIER - G. ROUGEMONT, in $B E 1990,23$ ]. We give here only the concordances to the ed. pr. (V), and register some new readings of $\mathrm{S}$.: $552 \mathrm{~S}=11 \mathrm{~V} ; 1305-1310 \mathrm{~S}=5-10 \mathrm{~V} ; 1305 \mathrm{a} \mathrm{S}=5 \mathrm{a} \mathrm{V} ; 1312 \mathrm{~S}=12-13 \mathrm{~V} ; 1314 \mathrm{~S}=$ $14 \mathrm{~V}$ (according to $\mathrm{S}$. there is no place for the restoration of the name of Hera after that of Zeus Panamaros; the text is a dedication of a fountain near the bouleuterion); $1315-1318 \mathrm{~S}=15-18 \mathrm{~V} ; 1320 \mathrm{~S}=20 \mathrm{~V} ; 1325 \mathrm{~b} \mathrm{~S}=25 \mathrm{~b} \mathrm{~V}$ (S. gives many new restorations); $1328 \mathrm{~S}=28 \mathrm{~V} ; 1046$ add. $\mathrm{S}=1 \mathrm{~V}$ (some restorations); 1048 add. $\mathrm{S}$ $=2 \mathrm{~V} .[\mathrm{AC}]$

269) H. Salamé-SaRkis, Heliopolitana Monumenta, in Berytus, 35 (1987) [1989], p. 126-139 [SEG 38, 1562]: Ed. pr. of one Greek and two Latin dedications to Hermes Kyrios Soter/Mercurius Dominus (6-8, Heliopolis, 1st-3rd c. AD). [ES]

270) G.D.R. Sanders - R.W.V. Catling, From Delos to Melos: A new fragment of IDelos 1562, in ABSA, 85 (1990), p. 327-332: A fragmentary inscription found on Melos was originally part of the monument of Mithridates on Delos. This find permits the restoration of the dedicatory inscription for this monument, which was dedicated to the Megaloi Theoi Samothrakes Dioskouroi Kabeiroi and Mithridates VI by a priest of Poseidon Aisios and the Samothracian Gods (102/01 BC, I.Delos 1562,). [AC]

271) A. Savelkoul, Un néocore de Zénoposéidon à Mylasa, Machon, fr. 8 Gow (= Athen., VIII, 337C), in AC, 57 (1988), p. 274-279 [SEG 38, 1068]: S. identifies the sanctuary of Zenoposeidon mentioned by Machon (ap. Athen. 337C)

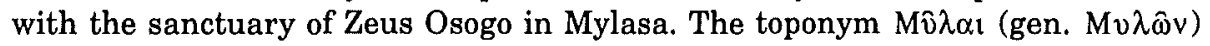
should be considered as the shortened variant of Mylasa. The author focuses especially on the functions of the neokoros; from the study of two inscriptions [I.Mylasa 308. 347] she infers a tripartite rôle of the neokoros, as a cult servant, an eponymous magistrate, and an administrator of financial transactions. According to $S$. the neokoros was attached to the tribe of the Otorkondeis, since this tribe administered the temple of Zeus Osogos. [H.W. PLEKET, in SEG 38, 1068 rightly points out that the inscriptions cited above do not support S.'s conclusions and do not deliver either additional information about the functions of the neokoros, beside that of a cult servant, nor any proof about his affiliation to the tribe of Otorkondeis. For the epitheton Zenoposeidon as an attribute of Zeus Osogo and the related inscriptions, also cf. I.Mylasa 319-327]. [ES]

272) A.N. Š Čgglov, Un établissement rural en Crimée: Panskoje I (Fouilles de 1969-1985), in DHA, 13 (1987), p. 239-273 [SEG 38, 755]: In his report on the excavations in Panskoje (territory of Chersonesos) S. mentions some graffiti on vases (4th c. BC). [The edd. of $S E G 38,755$ read on the photos i $\varepsilon \rho \dot{\alpha}$

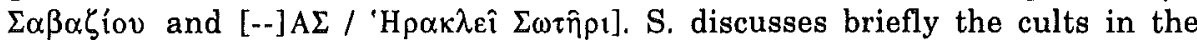
Chersonese, especially the main cults, namely those of Demeter and Sabazios, as the protecting gods of agriculture, and that of Herakles Soter, the patron god of the Chersonese. [ES]

273) P. Scherrer, I.O.M.K. Zur Deutung des Gottes auf dem Pfaffenberg bei Carnuntum, in H. Vetters - M. Kandler (edd.), Akten des 14. Internationalen Limeskongresses 1986 in Carnuntum, Wien, 1990, 2, 
p. 625-638: S. strengthens the view that the abbreviation I.O.M.K. on a series of dedications from Carnuntum, which commemorate an event on June 11th 172, refers to Iuppiter Optimus Maximus Kasius (Baal Zaphon-Kasju, the Greek Zeus Kassios, assimilated in Egypt with Horus) [cf. EBGR 1987, 100]. These dedications refer to the rain- and thunderbolt-miracle during an expedition of Marcus Aurelius. Zeus Kasios was a weather-god regarded as a protector of kings and states. The rain-miracle occurred, according to Cassius Dio $(72,8 \mathrm{ss}$ ), after the Egyptian

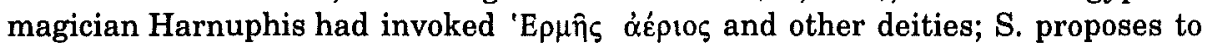

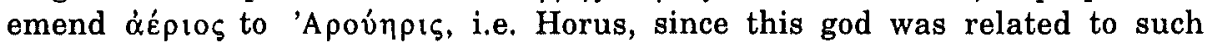
phenomena and was usually associated with Zeus. The iconography of the Juppiter-columns and the Zeus-Kasios-statue from Pfaffenberg (Carnuntum) reflects Egyptian religious elements related to the myth of the struggle of Horus and Thot with Seth. [AC]

274) P. Scherrer, Augustus, die Mission des Vedius Pollio und die Artemis Ephesia, in JÖAI, 60 (1990), p. 87-101 [BE 1991, 80; 1992, 239]: In his decree concerning matters of the Artemision of Ephesos (election of the priests, the question of hymnodoi) the governor of Asia Paullus Fabius Persicus refers to a constitutio of $\mathrm{P}$. Vedius Pollio, which according to S. was the lex templi of the Artemision. After a study of the epigraphic testimonies on Pollio's journey to Greece and Asia Minor (probably ca. 27-25 BC) S. argues that his activity concerned the establishment of Augustus' cult; the right of certain sanctuaries to inherit (Artemision of Ephesos, Didymaion, Nemeseion of Smyrna, the sanctuary of Athena in Ilion and of Meter Theon Sipylene; cf. ULPIANUS 22,6) was probably established by Pollio. The archaeological evidence makes probable that the great altar in front of the Artemision was dedicated to Augustus; another cult-place for the imperial cult existed at the Southern Agora. [AC]

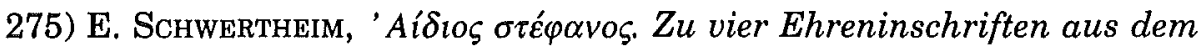
Territorium von Kyzikos, in Mysische Studien, p. 83-100: 1) Ed. pr. of a

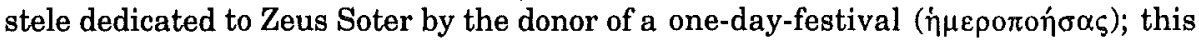
stele was used later by the inhabitants of an anonymous kome of Kyzikos to inscribe honorific inscriptions for persons responsible for local festivals. The texts name three functionaries: donors of festivals ( $\dot{\eta} \mu \varepsilon \rho \pi$ on $\sigma \alpha \nu \tau \varepsilon \varsigma$ ), agonothetai, and

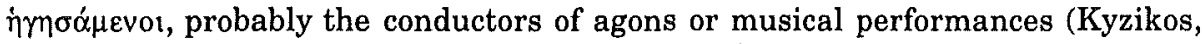
1st c. BC). These persons were honoured with an $\alpha \dot{\alpha} \delta$ io $\sigma \tau \varepsilon \dot{\varphi} \varphi \alpha v 0 \zeta$. 2) An inscription published by F.W. HASLUCK, in JHS, 27 (1927), $65 \mathrm{n}^{\circ} 9$ (area of Kyzikos), is a similar honorific inscription for three agonothetai. 3) Restoration and discussion of the text F.W. HASLUCK, Cyzicus, Cambridge, 1910, IV, p. 88: Honorific inscriptions mentioning the $\alpha \dot{\alpha} \delta 10 \varsigma \sigma \tau \varepsilon \dot{\varphi} \varphi v o \varsigma$ given to dead persons were inscribed on a stele originally dedicated to Zeus (area of Kyzikos). 4) Ed. pr. of a stele recording the awarding of an $\alpha \dot{\alpha} \delta$ ios $\sigma \tau \varepsilon \dot{\varphi} \alpha \nu \circ \varsigma$ to various benefactors for their contribution to a Dionysiac festival; their donations included the financing of an $\dot{\eta} \mu \varepsilon \rho o \pi$ ó provision of wine or another drink), theatrical and musical performances, the donation of vessels and masks, the construction of a stage, and the composition of

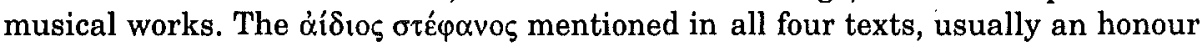
bestowed on dead persons, implies the periodical award of a garland to the honoured person. [AC] 
276) C. Segal, Dionysus and the gold tablets from Pelinna, in GRBS, 31 (1990), p. 411-419: Discussion of the Dionysiac elements in the new Orphic texts from Thessaly [cf. supra $\mathrm{n}^{\circ}$ 91. 107. 113. 149]. Beside the epitheton Bakchios, the ivy-shape of the lamellae, and the mention of wine in the new texts $\mathrm{S}$. underlines their rhythmic structure; these texts were suitable for oral performance, probably during the funerary ritual (rather than during the initiation). The ivy-shape of the tablets may symbolize the persistent vegetative life-energy, thus evoking the expectation of life after death. A stylistic analysis of the texts reveals a progression from the urgent tone of the first verses to the calmer mood of the last line, which expresses the calm view of the future that awaits the initiate. The idea of 'falling into milk' is associated with Dionysiac salvation. The new texts enrich our picture of Dionysos and underline his rôle as the god who aids men in their crossing of the boundary between life and death. [AC]

277) N.V. Sexunda, IG $i i^{2}$ 1250: A decree concerning the lampadephoroi of the tribe Aiantis, in ZPE, 83 (1990), p. 149-182: Detailed study of the evidence on torch-races of the ephebes in classical Athens. S. argues that before 335 the Athenian ephebes participated in annual torch-races at three festivals (Panathenaia, Hephaistia, Prometheia), of which only the torch-race for the Hephaistia was a relay-race; he interprets $I G \mathrm{II}^{2} 1250$ as a decree of a tribal assembly honouring a gymnasiarch for his victory in a torch-race, probably in the Hephaistia. The relay team included ten ephebes. [AC]

278) M. Seyer, Zur Grabung in den Hanghäusern, in KST, 10.2 (1988), p. 117-122 [SEG 38, 1459; $B E 1990,178]$ : Mention of a small altar dedicated to Artemis Pergaia (Limyra, imp.), whose cult was probably introduced to Limyra from Perge after the joining of the provinces Lycia and Paphylia (AD 43). [AC]

279) F.V. Shelov-Kovedyaev, A Berezan hymn to the island and Achilles, in $V D I, 1990.3$, p. 49-62 [BE 1991, 419]: Ed. pr. of a metrical dedication to Achilleus Pontarches (Berezan/Olbia, 1st c. AD); the heros is characterized as $\dot{\alpha} \theta \alpha\left[v \alpha \tau^{\prime} 01\right] \sigma ı v_{\text {ioo }}$ and is called up to accept the sacrifices and be merciful ( $\delta \delta^{\prime} /\left[\xi^{\prime}\right.$

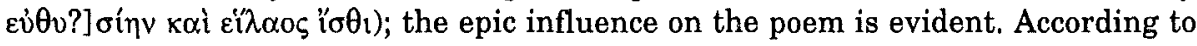
$\mathrm{S}$. Achilles had syncretic features as a water, equine and chthonic deity. His cult was transferred in Roman times from the island Leuke to Berezan. [AC]

280) J.C. Shelton, Greek Ostraca in the Ashmolean Museum, Firenze, 1988 [SEG 39, 1704; $B E 1991,644]$ : Restoration of a proskynema to the crocodile-

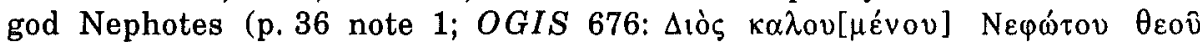
$[\mu] \varepsilon \gamma(\sigma \tau o v)$. The god is also mentioned in two ostraca from Thebes [cf. the additional remarks of J. BINGEN, in BE 1991, 644]. [AC]

281) P. Siewert - H. TÄUber - M. Sayar, Ergebnisse eines epigraphischen Forschungsaufenthaltes in Ost-Kilikien, in AST, 8 (1990), p. 241-243 [BE 1992, 541]: Reference to two unpublished funerary inscriptions from Mopsuhestia (Yakapinar, East Kilikia) for two priestesses. The first woman was

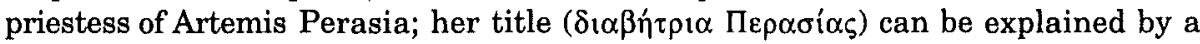
custom described by Strabon (XII 2,7): The priestesses walked with bare feet over glowing coal [cf. W.D. FURLEY, Studies in the Use of Fire in Ancient Greek Religion, Salem, 1988, p. 213-22]. The second woman was priestess of Artemis Leuko- 
phryene. It is not clear whether she was priestess at the temple of this goddes in Magnesia on Maeander or at another, still unattested sanctuary of Artemis Leukophryene in Kilikia. [ES]

282) P.J. SijPesteijn, SB I 5802: A reedition, in $Z P E, 82$ (1990), p. 102 [BE 1991, 626]: S. restores $S B$ I 5802 (Fayoum) as a dedication to Souchos Theos Megas Propator (not Sarapis as suggested by A. BERNAND) for emperor Claudius; he dates the inscription to $\mathrm{AD} 45-48$. [AC]

283) P.J. SIJPESTEIJN, A dedication to Isis. SEG XXXI 1532 re-dated, in Tyche, 5 (1990), p. 175-176: S. restores a dedication to Isis (Philai, SEG 31, $1532=$ $E B G R$ 1989, $8 \mathrm{n}^{\circ} 328$ ); it should be dated to $\mathrm{AD} 186$ (not $\mathrm{AD} 135$ ). [AD]

284) P.J. SiJPESTEIJN, Inscriptions from Egypt, in CE, 65 (1990), p. 122-125 [BE 1991, 632]: S. restores an inscription from Denderah (A. BERNAND, Les portes $d u$ désert, Paris, 1984, p. 142-143) as the dedication of a building to the local gods (Aphrodite and Hera or Isis?) for Trajan (AD 105-6). [AC]

285) U. Sinn, Die Votivgabe eines Athleten in Olympia, in Festschrift Himmelmann, p. 65-70 [SEG 39, 400; BE 1991, 119]: Ed. pr. of a dedicatory inscription addressed to Zeus Olympios on a bronze statuette of an athlete (Olympia, late 6th c. BC). According to S. the statuettes dedicated at Olympia were thanks-giving votives after a victory as well as votives of prayer for the victory. [AC]

286) J. Śliwa, Eine unbekannte 'Abrasaxgemme' aus der Sammlung von K. Schmidt-Ciazynski, in P.O. SCHOLZ - R. STEMPEL (edd.), Nubia et Oriens Christianus. Festschrift für C. Detlef G. Müller zum 60. Geburtstag, Köln, 1988, p. 445-448: Ed. pr. of a gem (green jaspis) with the representation of a syncretic creature (head of a cock, snake-legs) carrying a shield and a whip; the magic names IA $\Omega$ and 'A $A \rho \alpha \sigma \alpha \dot{\alpha} \xi$ are inscribed on the two sides of the gem. [AC]

287) Sotheby's Catalogue, London, Antiquities, Monday/Tuesday 10th/ 11th July 1989, p. $70 \mathrm{n}^{\circ} 192$ [SEG 39, 1725]: See supra $\mathrm{n}^{\circ} 52$.

288) Sotheby's Catalogue, London, Antiquities, Monday 22nd May 1989, p. 109-110 $\mathrm{n}^{\circ} 355$ [SEG 39, 1726]: Dedication to Apollon Alsios and Meter Leto (unknown provenance, 1 st/2nd c.). [Non vidimus].

289) G. Spadea Noviero, Documenti epigrafici dal sanctuario di Era Lacinia a Capo Colonna, in PP, 45 (1990), p. 289-312: Catalogue of the inscriptions found so far at the sanctuary of Hera Lakinia (Kroton) [cf. $E B G R$ 1989, 41]: dedicatory inscriptions on altars (2.3.8), bronze leaves (4-6) a vase (1), and a lamp (7); $n^{\circ} 8$ is in Latin. All inscriptions, except for $n^{\circ} 5$, record the name of the goddess Hera, with the epithets Lakinia and perhaps Eleutheria; the last epithet may be related to the function of the deity as protector of the manumitted slaves. [ES] 
290) A.J.S. Spawforth, Agonistic festivals in Roman Greece, in Greek Renaissance, p. 193-197 [BE 1991, 171]: The province Achaia had a privileged position in the agonistic world of the imperial times due to the fact that beside the numerous local agones it hosted the four festivals of the periodos (Olympia, Pythia, Nemea, Isthmia) and another six iselastic festivals (Asklepieia of Epidauros, Olympia Kommodeia in Sparta, and Panhellenia, Olympia, Hadrianeia, and Panathenaia in Athens). These festivals had great ecomomic and social importance. [AC]

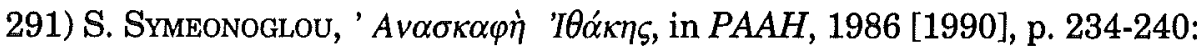
A graffito on an amphora dedicated to Apollon permits the localization of the god's sanctuary in Ithaka (hill Aetos) [cf. EBGR 1988, 126]. [AC]

292) H. TAEUBer, Arcadian inscriptions as a source for ancient Greek law, in Peloponn. Spoudes, 2, p. 353-358: Discussion of the "Gottesurteil von Mantineia" [cf. infra $\mathbf{n}^{\circ} 298.299$ ], which attests for a joint action of sacred and profane instances in the condemnation of murderers in the sanctuary of Athena Alea. T. argues that the oracle condemned the persons whose guilt was obvious, whereas the verdict $(\gamma v \omega \sigma i \alpha)$ of the profane instances concerned itself only with one person who either claimed that he had nothing to do with the murder or was the leader of the murderers, but did not slay the victims with his own hands. [AC]

293) F. TAGLietti, Sepolture e riti nella necropoli dell'Isola Sacra. Il lato ovest. Le tombe non architettoniche: $i$ tipi di sepoltura, in Bolletino di Archeologia, 5-6 (1990), p. 75-87: Ed. pr. of an epitaph with the unusual

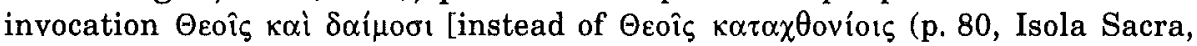
near Rome, imp.). [AC]

294) A. Tataki, Ancient Beroea: Prosopography and Society (Meletemata 8), Athens, 1988 [SEG 38, 583. 590; $B E$ 1989, 352. 439]: In the second part of her study T. discusses the theophoric names of Beroia (p. 387), which are usually names of gods (e.g. Artemis, Hermes). Notice the study of the sacred magistrates (priests of the Polis, Asklepios, Atargatis, Athena, Dionysos, Herakles Kynagidas, Isis Lochia, Meter Theon in Leukopetra; priestesses of Artemis Digaia, Ennodia, Meter and Kore, Meter Theon in Leukopetra, the Syrian Parthenos or Atargatis) and their social rôle and economic status in the community (p. 429, 432, 469-471, 484,489 ). Referring to the manumissions or donations of slaves in Beroia and its territory T. points out that they are connected with female deities, mostly with the sanctuary of the Mother of the Gods in Leukopetra [cf. EBGR 1987, 45]. [ES]

295*) J. TeIXIDor, Sur quelques aspects de la vie religieuse dans la Syrie à l'époque hellénistique et romaine, in Syrie, p. 81-95: Using the literary and epigraphic evidence T. gives an overall picture of religious life in Hellenistic Syria: Discussion of: the association of indigenous deities with Greek and Egyptian gods (e.g. Astarte-Aphrodite-Isis: ID 2132; Zeus Megistos of Heliopolis, regarded as an Egyptian god: IGLS 2731); the various cults of Zeus (associated with Baalshamîm and Hadad) as protector of fertility and god of the heights, the thunderbolt, and the sky; the association of the Eleusinian with Oriental cults (p. 8283); the cult of goddesses, especially Astarte (associated with Aphrodite, Tyche, Isis, Ishtar, and Allat, usually identified with Athena or Artemis), Allat, Manat 
(associated with Nemesis), and other Arabic deities; the cult of Hadad and Atargatis; the religious symbols and forms of cult (altars, statues, the thunderbolt as a symbol of Zeus, the carrying of thunderbolts in processions, the cult epithets epekoos, megas, kyrios, and soter); the religious associations; the interference of the Seleucids in religious matters (privileges of sanctuaries, hiera ge, asylia, and hikesia); the great sanctuaries (especially in Baitokaike and Heliopolis) and the shrines in quarters of towns ( $\alpha \mu \varphi \circ \delta o v)$; the royal cult. [AC]

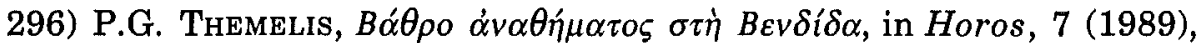
p. 23-29 [SEG 39, 210; $B E 1992,111]$ : Ed. pr. of a dedication to Bendis by a Thracian after his victory in a torche race (probably at the local Bendideia, Maroneia, Attica, 4th/3rd c.); $T$. discusses the cult of Bendis in Attica. [AC]

297) P.G. Themelis, 'E $\lambda \varepsilon v ́ \theta \varepsilon \rho v \alpha$, in Kretike Hestia, 3 (1989/90), p. 266-270 [SEG 39, 958]: T. mentions two dedicatory inscriptions from Eleutherna (Crete, hell.): 1) A pillar dedicated to an unknown deity (or deities?); the text reads:

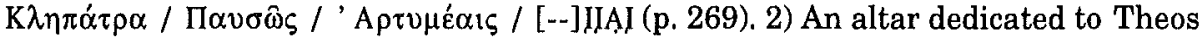
Hyetios. [Cf. SEG 39, 958: The god is probably Zeus; the cult of Zeus Hyetios was not attested so far on Crete, but CALLIM., fr. 100 reports a rain miracle of Zeus on Crete; see H. VErbrugaen, Le Zeus crétois, Paris, 1981, p. 144-145]. [AC]

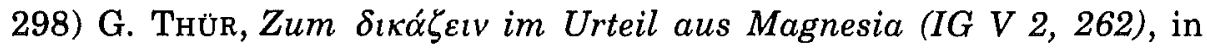
G. ThÜR (ed.), Symposion 1985. Vorträge zur griechischen und hellenistischen Rechtsgeschichte, Ringberg, 24-26 Juli 1985, KölnWien, 1989, p. 55-69 [SEG 39, 393; BE 1990, 422]: Discussion of the 'Gottesurteil von Mantineia' [cf. EBGR 1989, 113; supra n ${ }^{\circ} 292$, infra ${ }^{\circ} 299$ ], which records the condemnation of murderers. Some people were murdered at the sanctuary of Athena Alea; a group of persons accused of this deed sought asylum in the sanctuary (except for one); the judgment for these persons included two procedures: a) judgment by Athena through an oracle, and b) judicial verdict by the magistrates (for the person, who was not in the sanctuary). [AC]

299) G. Thür, Nachträge zum Urteil aus Mantineia (IG V 2, 262), in G. NencI - G. Thür (edd.), Symposion 1988. Vorträge zur griechischen und hellenistischen Rechtsgeschichte, Siena-Pisa, 6-8 Juni 1988, KölnWien, 1990, p. 277-282 [SEG 39, 393; $B E$ 1992, 261]: Bibliographical supplement and additional remarks to supra $\mathrm{n}^{\circ} 298$. [AC]

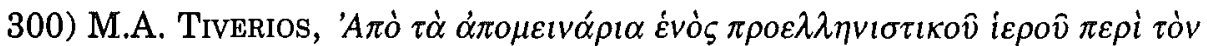
$\Theta \varepsilon \rho \mu \alpha \hat{\imath} o v$ кó $\lambda \pi o v$, in Mneme Lazaridi, p. 71-88: Presentation of a group of sherds probaby from the deposit of a prehellenistic sanctuary in the area of the later city of Thessalonike; among them the inscribed sherd of a kylix (late arch.)

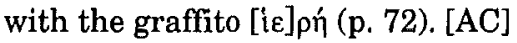

301) S.B. Tokntas'Jev, Review of B.I. Solomonik, Graffiti s khory Khersonesa, Kiev, 1984, in VDI, 1988.3, p. 167-178 [SEG 39, 749; BE 1990, 497]: Numerous corrections and restorations of graffiti published in the corpus of B.I. SolomoniK (Chersonesos): 'A ל̌tó (7) is a mythological name (cf. DION. HaL., Ant. Rom. I 11); T. recognizes a magical word in $n^{\circ} 470$ ( $\Lambda \mathrm{OBE} \Delta \mathrm{YZ}-$-); in $n^{\circ} 197$ he 


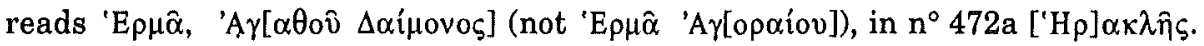
[AC]

302) I. Touratsoglou, Die Münzstätte von Thessaloniki in der römischen Kaiserzeit (32/31 v. Chr. bis 268 n. Chr.), Berlin-New York, 1988, [SEG 38, 689]: Survey of the testimonies for the cults of Roman Thessalonike (p. 10, 15-16 with note 70): cult of Augustus, Fulvus (the son of Marcus Aurelius), Roma and Zeus Eleutherios, the Roman benefactors, Apollon, Aphrodite Homonoia, Asklepios, Dionysos, the Dioskouroi, Heron, Kabeiros, Nemesis, the Nymphs, Zeus Hypsistos, the Egyptian deities, and Attis; collection of the evidence for cult associations (of Dionysos, the Egyptian deities, Asklepios, Attis, and Zeus Hypsistos, p. 16). [AC]

303) E. Trakosopoulou, in $A D, 39$ B (1984) [1989], p. 226 and pl. 113a [BE 1991, 408]: Mention of a record of sale (Olynthos, 4th c. BC). [M.B. HATzopouLOS, in $B E 1991,408$ reads on the photo the names of the witnesses, among them a priest]. [AC]

304) A. Trotta, in M. FABri - A. Trotta, Una scuola collegio di età augustea. L'insula II di Velia, Rome, 1989, p. 20-23 and 69-77 [SEG 39, 1078]: T. republishes the inscriptions on statues of the philosopher Parmenides and three i $\alpha \tau \rho o i$ i $\varphi \hat{\prime} \lambda \alpha \rho \chi 01$ (Elea/Nelia, ca. AD 50; SEG 38, 1020). After a review of earlier comments, she conducts a thorough analysis of the names Oulios, Oulis, Ouliades and their connection to the cult of Apollon Oulios [cf. now $E B G R$ 1988, $111]$. In this context the title $\varphi \omega \hat{\lambda} \alpha \rho \chi 0 \varsigma$ does not only reveal the didactic activity of the person in charge of the religious/philosophical medical school, but also the activity of this person as head of a cult association, which was probably also

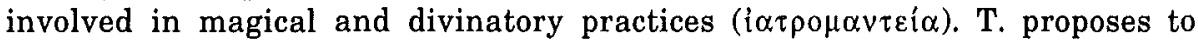
explain the name Oulis as a "nome iniziatico, usato exclusivamente all'interno dell'associazione-scuola". The dates given in the pholarchoi-inscriptions probably refer to an era beginning with the year of Parmenides' death (ca. $440 \mathrm{BC}$ ) rather than with the foundation year of Elea. [ES]

305) M. Tsimpidou, in $A D, 41$ B (1986) [1990], p. 150 [BE 1991, 398]: T. mentions a new funerary altar found in Charakoma (between Thessalonike and Kilkis, imp.). [M.B. HATZOPOULOS, in $B E$ 1991, 398 associates the names of one of the dedicants, Heliodora, with the cult of Helios in the region of the Paiones]. [AC]

306) I. Tsirigoti, in $A D, 36$ B (1981) [1988], p. 48 [SEG 38, 193]: Mention of a stele dedicated in fulfillment of a vow (Attica). [AC]

307) A. Tziafalias, in $A D, 40$ B (1985) [1990], p. 205-207: T. mentions numerous inscriptions found in Thessaly. Atragas: A dedication to an anonymous deity (1. 4th c. BC); a dedication to Zeus (?, e. 4th c. BC). Prinos Trikalon: Six marble dolphins, one of them with a dedicatory inscription to Poseidon (1. 4th c. BC).

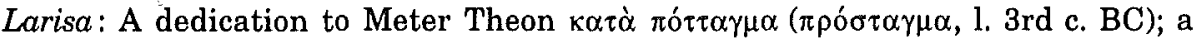
dedication to an anonymous deity (4th c.). Kastri Agias: A dedication to Poseidon

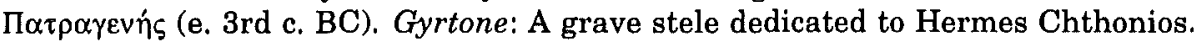
[AC] 
308*) F.T. VAN Straten, Unclassical religion in classical Greece, in Praktika Klas. Arch., 4, p. 288-292: In a brief discussion of reliefs dedicated to heroes (mainly of the 4th c. BC), V.S. discusses the names of heroes inscribed on the reliefs. These names reflect the properties attributed to the heroes: horsemanship (Zeuxippos, Chrysippos, Hippalkmos), martial character (Aleximachos, Symmachos), benevolence towards men in need (Eukolos, Sosineos, cf. the epitheton éríkoos), and protection of the agriculture (Bouthon, Eudosia). [AC]

309) E. VARINLIOĞLU, Die Inschriften aus dem Museum von Usak, in EA, 15 (1990), p. 73-105 [BE 1991, 508]: Ed. pr. of several inscriptions from Lydia. 23) The grave inscription of a 9 years-old boy who had been dedicated to Apollon by his parents ( $\kappa \alpha \theta \varepsilon \imath \varepsilon \rho \omega \sigma \alpha v)$, i.e. the boy would serve the god as his priest. The epitaph states that the boy 'had received special praise from Apollon' ( $\tau$ 'v $\tau \varepsilon \uparrow \eta \eta \theta \dot{\varepsilon} v \tau \alpha$ i $\pi$ ò 'A ó$\lambda \lambda \omega \vee \circ \varsigma)$; according to A.D. NocK, in $J H S, 45$ (1925), p. 100 "the grace might be the reception of prophetic dreams, or other supernatural gifts". 41) The grave inscription of a stephanephoros of Maionia (AD 211/2), 46) A

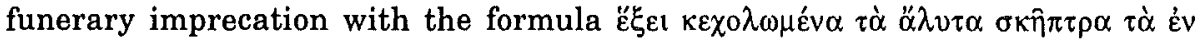
T $\alpha \beta \alpha$ ors (AD 234/5); V. comments on this curse. 50) A funerary imprecation with

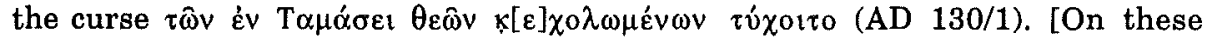
curses cf. supra $\left.\mathrm{n}^{\circ} 167\right]$. [AC]

310) A. Verbank-PiérARD, Le double culte d'Herakles: légende ou réalité ?, in Entre hommes et dieux, p. 43-65 [SEG 39, 320. 1854]: V.-P. presents an interesting article on a much discussed subject. Her main point is that

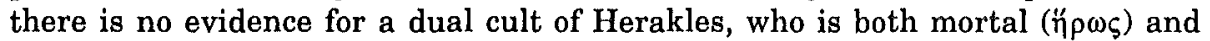
immortal $(\theta \varepsilon o ́$ ) after his apotheosis. This conclusion is based on the critical analysis of the literary testimonia (especially Herodotus and Pausanias), the archaological evidence, the inscriptions (Kos: LSCG $151 \mathrm{C}$; Miletos: LSAM 42; Thasos: LSCG Suppl. 63), and a detailed study of Herakles' cults in Attica. This evidence shows that Herakles was worshipped as a god by persons of every legal and social status; heroic rites, wherever attested, were combined with his cult as a god and represent a variant of the sacrifice. [ES]

311) A.-M. VÉrIlhac, Deux épigrammes funéraires d'Apamène, in Hommage à $G$. Roux, p. 211-224 [BE 1990, 94]: Discussion of a funerary epigram for a woman (Apameia, 3rd c. AD; GVI 727); her husband followed her in her death shortly after, desiring to join her soul in the underworld: $\pi v \varepsilon \hat{v} \mu \alpha$ rò oòv

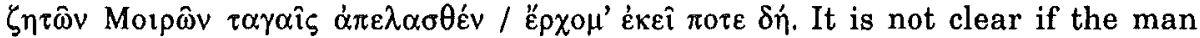
committed suicide or died because of his grief. $V$. gives further parallels for epigrams mentioning the voluntary reunion of relatives after death; the poet of this epigram was probably influenced by the passage on the suicide of Euadne (EUR. Suppl. 1012-1071). [AC]

312*) M.J. Vermaseren, Corpus Cultus Cybelae Attidisque. IV. Germania, Raetia, Noricum, Pannonia, Dalmatia, Macedonia, Thracia, Moesia, Dacia, Regnum Bospori, Colchis, Scythia et Sarmatia (EPRO, 50), Leiden, 1989 [SEG 39, 1855; $B E$ 1990, 139]: Collection of archaeological and epigraphic testimonies for the cult of Kybele/Meter Theon and Attis. [AC] 
313) P. VEYne, La nouvelle piété sous l'empire: S'asseoir auprès des dieux, fréquenter les temples, in $R P h, 63$ (1989), p. 175-194 [SEG 39, 215]:

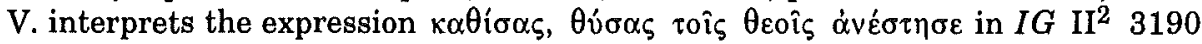
(Athens, $\mathrm{AD} \mathrm{126/7)}$ as a reflection of a new practice of personal piety in imperial times, i.e. praying and then sitting before the image of the god. He collects the literary sources pertaining to the same practice as well as to the regular visits of temples in imperial times. [On the later practice see also I.Cret. II, xxviii = SEG 33, 736]. [AC]

314) J.G. Vinogradov, Politiceskaja istorija Ol'vijskogo polisa, VII-I vv. do n.e. - Istoriko-epigraficeskie issledovanie, Moskva, 1989: Presen tation of the political history of Olbia (7th-1t c.) with ample use of inscriptions. $V$. discusses (p. 78-80) the archaic oracle of Didyma, following in general the interpretation of A.S. RUSJAEVA [cf. supra $\mathrm{n}^{\circ} 46$ ]. He mentions (p. 65-66) a still unpublished letter of a high priest concerning the inspection of sanctuaries (6th/5th c.). Also notice a still unpublished honorific epigram for a person who had paid

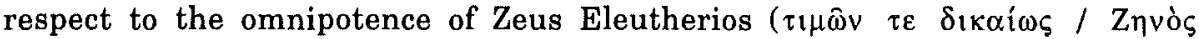

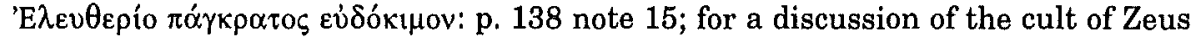
Eleutherios see p. 135-150). Among the texts discussed in connection with the political history of Olbia notice an inscription concerning the construction of a gate named after Ares (p. $257=$ I.Olbia 75), three honorific decrees mentioning the festival Dionysia (p. 153-156 = SEG 32, 704; p. 191-194 = SEG 34, 758; p. 215-216 = I.Olbia 28); the decree $S E G 34,758$ refers to sacrileges in connection with a stasis; the decree I.Olbia 28 was set up in the sanctuary of Apollon. [Cf. the review of F. BosI, in Epigraphica, 52 (1990), p. 249-255]. [AC]

315) J. Vinogradov, Review of M. Tacheva-Hitova, Eastern Cults in Moesia Inferior and Thracia (5th c. BC-4th c. AD) (EPRO, 95), Leiden, 1983 , in VDI, 1990.2 , p. $210-212$ : Critical review of the corpus of monuments related to Oriental cults in Moesia Inferior and Thracia. V. gives several new

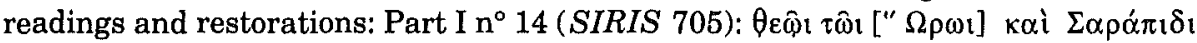

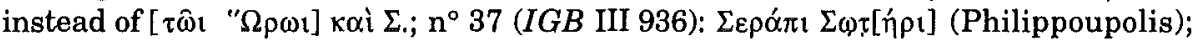

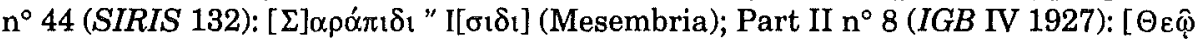

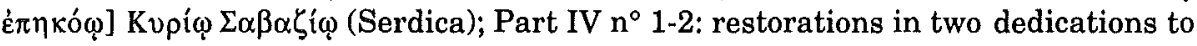

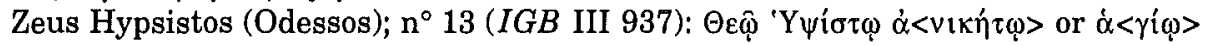
(Philippoupolis), [AC]

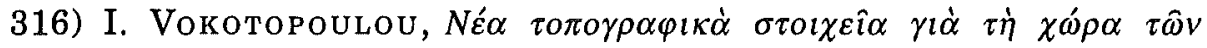
$X \alpha \lambda \kappa \imath \delta \varepsilon ́ \omega v$, in Mneme Lazaridi, p. 109-144 [BE 1990, 481]: Ed. pr. of a stele found in Chalkidike with the description of the boundaries of five Macedonian communities (Rhamaioi, Paraipioi, Kisseitai, Osbaioi, Kallipolitai). Three sanctuaries are mentioned as boundary marks (Hermaion, i.e. a hill or mountain with a shrine of Hermes, Dioskourion, and a sanctuary of Artemis). V. dates the inscription to ca. 292-289 B.C. [But see M.B. HATZOPOULOS, in $B E$ 1990, 473; he proposes an earlier date under the reign of Philipp II and discusses briefly the topographical questions; cf. M.B. HATZOPOULOS - L.D. LouKOPOULOU, Recherches sur les marches orientales des Téménides (Anthémonte - Kalindoia). 1ère Partie (Meletemata 11). Athens, 1992, p. ]. On p. 123-124 V. mentions three sale contracts found in Amigdalai and Plana (4th c.), in which the month names Apatourion and 
Heraion are mentioned. The eponymous priest in one of them may be the priest of Apollon in Olynthos. [But see now EBGR 1988, 68]. [AC]

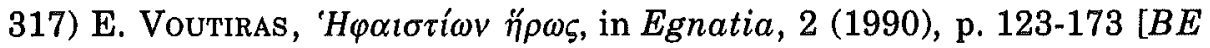
1992, 309]: Ed. pr. of a relief-stele dedicated to Hephaistion, the close friend of Alexander the Great (Pella?, late 4th c. BC). The dedicatory inscription, in which he is called $\ddot{p} \rho \omega s$, shows that Hephaistion was heroized and did not receive divine honours. V. offers an excellent study of the iconography of the stele (representation of a heroine and a young man standing by his horse and offering a libation) and other related monuments dedicated to heroes. [AC]

318) E. Voutiras, Review of T. Rizakis - G. Touratsoglou, 'Enı $\rho \alpha \varphi \dot{\varepsilon} \varsigma$

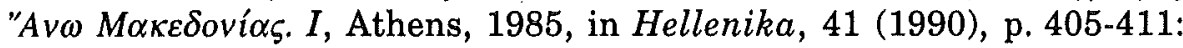
Review of I.Macedonia I [cf. EBGR 1989, 17], including minor corrections to texts of religious interest: $V$. reads in $n^{\circ} 4$ [Ev] $\chi \alpha \rho \imath \sigma \tau \eta \dot{\eta} \rho \iota \alpha$; the dedication to Theoi Epekooi in $n^{\circ} 23 a$ is partly metrical. [AC]

319) S. Walker, Two Spartan women and the Eleusinion, in Greek Renaissance, p. 130-141 [SEG 39, 374; $B E$ 1991, 130]: Study of two reliefs associated with the sanctuary of the Eleusinian Demeter at Kalivia (Lakonia, late 2nd c. $\mathrm{AD}$ ) and discussion of the epigraphic evidence related to this sanctuary. The main features of this cult, which witnessed a striking revival in the late 2 nd c. $A D$, were the prominence of women and the rite of banqueting, presided over by a

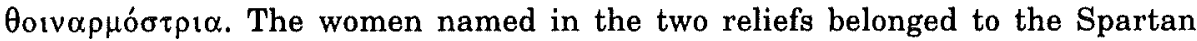
upper-class. Claudia Ageta, who had held the hereditary office of the priestess, was of senatorial family; her cousins were priest and priestess of Kore at Helos (Lakonia). The iconography of the reliefs reflects the grooming and cleansing of the participants in the cult of Demeter. These reliefs were not funerary sculptures, but commemorated a specific festival. [AC]

320) W.C. West, M. Oulpios Domestikos and the athletic synod at Ephesus, in $A H B, 4$ (1990), p. 84-89: I.Ephesos IV 1089 is a dossier containing an imperial letter to a synod of athletes ( $\sigma \dot{\mu} \mu \pi \alpha \varsigma$ $\xi v \sigma \tau o$ s) presided over by the M. Ulpius Domesticus (as high-priest) and the reply of the synod. These texts are part of the correspondence between Domesticus and the emperors Hadrian and Antoninus Pius concerning the relocation of the synod's headquarters from Ephesos (not Sardis) to Rome ( $I G$ XIV 1054-1055). W. collects the evidence for the activities of the synod in Ephesos (1st c. BC-2nd c. AD) and especially for the participation of the hieronikai in religious ceremonies as members of the xpvoouópor of Artemis. [AC]

321) F. Willemsen, Die Fluchtafeln, in supra $n^{\circ} 172$, p. 142-151 [BE 1991, 71]: Ed. pr. of 8 defixiones from Kerameikos (4th c. BC): A curse against a legal opponent (I 515, 4th c. BC); a curse, with invocation of Hermes Eriounios and Hekate, addressed against two men (I 520,5 th c. BC); notice the formulas $\kappa \alpha \tau \alpha \delta \omega$

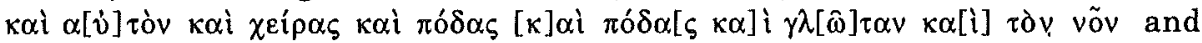

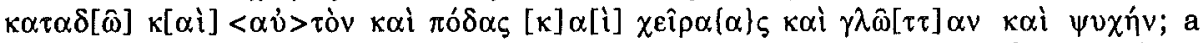

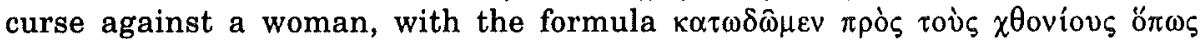

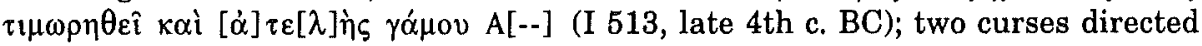


against men, among them the famous orators Lykourgos and Hypereides (I 518. 516, 5th and 4th c. BC); three fragments (I 519. 521. 524). [AC]

322) A. Wittenburg, Il testamento di Epikteta, Trieste, 1990 [BE 1991, 426]: A thorough study of the well known inscription concerning the cult association founded by Epikteta on Thera (ca. 210-15 BC; IG XII 3, 330). Two chapters are devoted to the foundation of the cult association (p. 89-119), the deities, whom the family shrine had been consecrated to, the festivities, and the phenomenon of awarding heroic honours to the dead (p. 121-138) [cf. the remarks of P. GAUTHIER, in $B E 1991,426$ on legal matters]. [ES]

323) M. WörRle, Inschriften von Herakleia am Latmos II. Das Priestertum der Athena Latmia, in Chiron, 20 (1990), p. 19-58: Ed. pr. of a dossier concerning the priests of Athena Latmia in Herakleia at Latmos. In the early 1st c. BC the city asked an oracle (probably that of Didyma), whether the priest office for Athena Latmia should be sold for lifetime or the priest should be elected every year (11. 3-7); the metrical oracle of Apollon demanded the election of a priest every year (11. 8-16). The two texts are followed by two fragmentary lists of the priests (1st c. BC-ca. AD 25); 57 (out of ca. 102) names of priests are preserved. W. discusses in detail the evidence for the cult of Artemis Latmia, the procedure followed for consulting the oracle, and Apollon's response, adducing numerous parallels (especially $L S A M$ 47: the oracle of Didyma concerning the collect for Artemis Skiris; TAM II $174=S E G 39,1413$ : an oracle concerning the priestess of Artemis in Sidyma). The preference given to the election of the priests, instead of the common procedure of putting up to auction the priest-office, may be due to grievances and problems connected with the latter. W. gives a detailed prosopographical and historical commentary. Notice that the goddess took over the priest office for four years, probably in a critical situation; three priests occupied this office twice, two of them three times; family relations can be found in several cases. [AC]

324) V.-P. YaILENKo, Les maximes delphiques d'Ai Khanoum et la formation de la doctrine dhamma d'Asoka, in $D H A, 16.1$ (1990), p. 239256: $Y$. recognizes a striking parallelity in content and phraseology between the ethical principles expressed in the 'Delphic Commandments' inscribed in the heroon of Kineas in the Greek city at Ai Khanoum (Baktria, late 4th c. BC) and the edicts of Asoka, king of the Maurya, known from Greek and Aramaic inscriptions. These principles concern the attitude towards the family and the parents, the proper forms of behaviour, the right administration, self-discipline etc. In view of the contacts between the kingdom of the Maurya and the Greeks it seems reasonable to assume that Asoka's doctrine was inspired not only by Buddism, but also by the 'Delphic Commandments'. [AC]

325*) L.V. ZaBkar, Hymns to Isis in Her Temple at Philae, HanoverLondon, 1988 [SEG 38, 2014]: Edition and analysis of the hieroglyphic hymns to Isis (Philai, 3rd c. BC). On p. 135-160 Z. studies the relation between these texts and the Greek aretalogies of Isis found in inscriptions. Z. argues that the author of the original Greek composition derived the strong Egyptian element from sources easily accesible to him (like the hymns of Philai); he translated some Egyptian 
phrases into Greek, adding at the same time typical Greek statements. This original text was later adopted to particular religious needs. [AC]

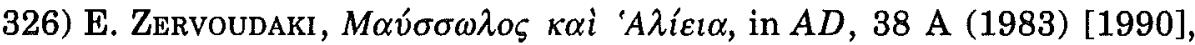
p. 249-257 [BE 1992, 145]: Ed. pr. of a sherd of an amphora given as prize at the Rhodian Halieia. A fragmentary inscription painted over the head of Helios may

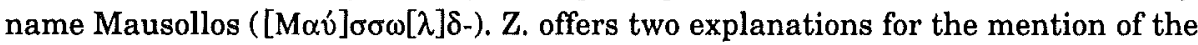
Karian dynast on the prizes given to the victors of the Halieia: a) The festival may have been dedicated to him after he had supported the Rhodians in the war of 357355 ; b) these Halieia were celebrated in the same year with the funeral games for Maussolos (352 BC). [See the objections of M. SÈVE, in BE 1992, 145]. [AC]

327) K. Zimmermann, Archaische Dachterrakotten aus Histria, in Hesperia, 59 (1990), p. 223-233 [BE 1991, 105]: Z. mentions (p. 228) a roof tile with a dedicatory inscription addressed to Aphrodite (Histria, early 6th c. BC); it attest the existence a shrine of Aphrodite in archaic times. [AC]

\section{Addenda}

Notice the remarks (restorations, interpretations et sim.) of the contributors to $S E G$ and $B E$ on inscriptions presented in previous issues of the $E B G R$ :

EBGR 1988, 144 (a 'confession inscription'): C. BRIXHE - A. PANAYOTOU, in BE 1990, 696.

$E B G R, 1989,11$ (decrees of Olymos about building activities and rituals at the sanctuary of Leto; an inscription mentioning a prophetes in Olymos): P. Gauthier - G. Rougemont, in BE 1990, 21; H.W. Pleket, in SEG 39, 1135. 1138 .

$E B G R$ 1989, 48 (asylia of sanctuaries in Asia Minor): P. GAUTHIER, in $B E 1990,307$.

EBGR 1989, 55 (list of contributors, Ephesos): P. HerRmann - H.W. Pleket, in SEG 39,1176 .

$E B G R$ 1989, 79 (dedication to Theos Hypsistos, Cyprus): J. BINGEN, in SEG 39, 1554.

$E B G R 1989,100$ (vow to the gods of the underworld for the healing of a sick son, Chios): J. B OUSQUET, in SEG 39, 883.

$E B G R$ 1989, 123 ('confession inscriptions'): C. B RIXHE - A. PANAYOTOU, in BE 1991, 506; H.W. PLEKET, in SEG 39, 1275-1279.

Add in $E B G R$ 1989, 98: R. restores in the lex sacra for the cult of Men in Sounion (LSCG 55, 1l. 24-25, 2nd/3rd c.) $\dot{\alpha} \kappa \rho \circ \alpha[\mu \alpha \tau \alpha]$ instead of $\dot{\alpha} \kappa \rho o ́ \delta \rho v \alpha(S E G 39$, 153).

Angelos Chaniotis

Eutychia Stavrianopoulou

Seminar für Alte Geschichte

Martstallhof 4

D - 69117 HEIDELBERG 